
THE UNIVERSITY OF MICHIGAN

CENTER FOR CHINESE STUDIES

MICHIGAN PAPERS IN CHINESE STUDIES

No. 16 


\title{
AN ANNOTATED BIBLIOGRAPHY \\ of \\ CHINESE PAINTING CATALOGUES AND RELATED TEXTS
}

Hin-cheung Love11

Freer Gallery of Art

Smithsonian Institution

\author{
Ann Arbor \\ Center for Chinese Studies \\ The University of Michigan
}

1973 
Open access edition funded by the National Endowment for the Humanities/ Andrew W. Mellon Foundation Humanities Open Book Program.

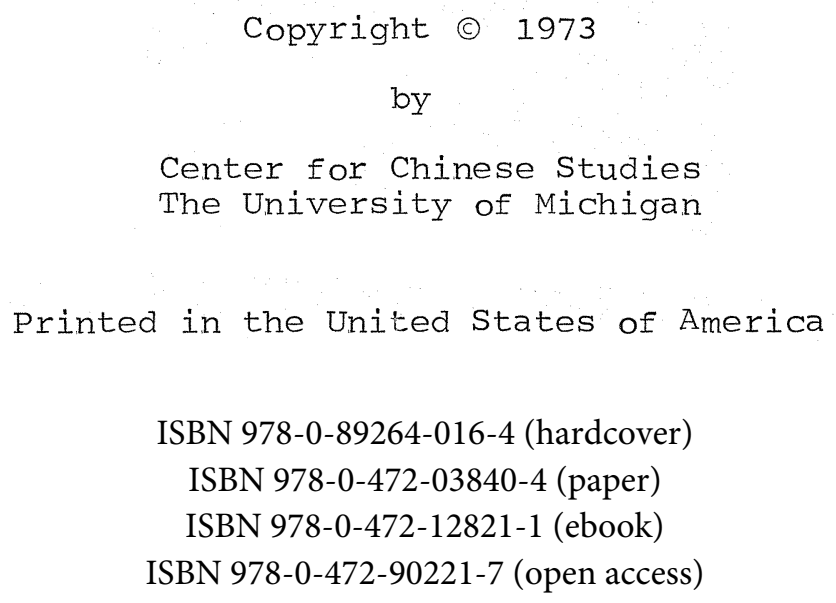

The text of this book is licensed under a Creative Commons Attribution-NonCommercial-NoDerivatives 4.0 International License: https://creativecommons.org/licenses/by-nc-nd/4.0/ 
Table of Contents

Preface............................

List of Abbreviations...................

ANNOTATED BIBLIOGRAPHY of the 108 titles in

John C. Ferguson's Ii-tai chu-1u hua mu.......1

ANNOTATED BIBLIOGRAPHY of 22 additiona 1

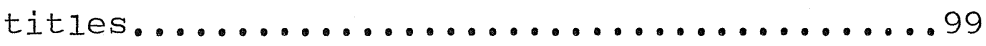

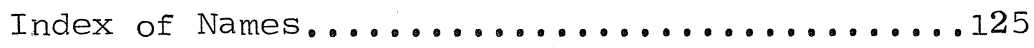

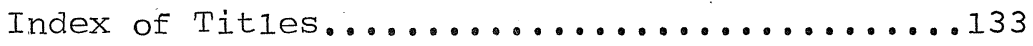


Preface

The student of Chinese painting who is at a 11 concerned with its textual aspects must from time to time consult John C. Ferguson's Ii-tai chu-lu hua mu 歴代著銥水番目 (Peking, 1934; reprint: Taipei, 1968), an index to Chinese paintings recorded in Chinese catalogues. Having consulted Ferguson, he is certain to want to know more about the catalogues in which the paintings are recorded: their compilers, the date of their compilation, their scope, their derivation, their merits and shortcomings, and so on.

\section{This Annotated Bibliography of Chinese Painting}

Catalogues and Related Texts grew out of notes I had been making for my own reference since 1969. It occurred to me that there might be a need for an annotated bibliography in English among students whose knowledge of Chinese is not proficient enough for them to consult the annotated bibliographies which exist in Chinese, princi-

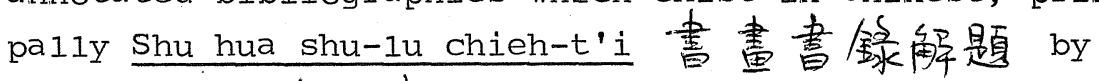
Yii Shao-sung 余紹宋 (Peking, 1932; reprint: Taipei, 1968), and Ssu-pu tsung-1u i-shu pien 四部總錄塑街編 by Ting Fu-pao J福保 and Chou Yün-ch'ing 周零青 (Shanghai, 1957). To those who have no difficulty with the language, the bibliography may be a tool providing the basic information on the catalogues in an easily available form.

Essential1y, then, the Annotated Bibliography is a companion to Ferguson, and as such, it consists of a review of each of the 108 titles used by him in Li-tai chu-lu hua mu as given in his bibliography. The reviews 
are arranged as far as possible in a chronological order according to the date of compilation. They are numbered consecutive1y from " 1 " to "108".

The heading at the beginning of each entry gives the following information:

(a) The name of the compiler.

(b) The title of the text.

(c) Whenever possible, the date of compilation. This information is usually in the author's preface or someone else's preface. If no such information is available, an approximate date will be given in the entry, and the date of the compiler's death will determine the position of the review.

(d) The number of chiian in the text.

(e) In parentheses, a cross-reference to the numbering system used in Ferguson's bibliography. For example, in my first entry, (Ferguson, 9, 12) indicates that the text Chen-kuan kung ssu hua shih is listed in Ferguson's bibliography as the twelfth title under the nine-stroke group because the first character chen has nine strokes.

(f) Citation of the most recent, most easily accessible and least expensive edition or editions. In many cases, this means the editions in Mei-shu ts'ung-shu and I-shu ts'ung-pien, or the most recent facsimile reprints in the I-shu shang-chien hsian-chen series produced in Taipei. These publications are readily available and inexpensive enough to be within the reach of the serious student and certainly of those universities where the study of Chinese art is a recently established discipline. The student who 
feels inclined to explore the problem of textual variations in different editions can do so on his own initiative. In the small number of instances where the rule of citing a recent edition or reprint is not feasible, the citation is to the particular edition I used.

(g) In the cases of those titles not included in Mei-shu ts'ung-shu, I-shu ts'ung-pien, I-shu shang-chien hsian-chen, or excerpted in p'ei-wenchai shu hua p'u, the name of the institution given in square brackets indicates the source of the text consulted.

In addition to the reviews of the 108 titles used by Ferguson, there is a supplement of reviews of twenty-two other texts not used by him but which are pertinent to our purpose. Some of these were compiled after 1934 and others were simply not used by him either because they were unavailable or unknown to him. These reviews, bearing numbers "S.1" to "S.22", are also arranged chronologically and are given the same treatment as the other 108 titles. This list of twentytwo is by no means an exhaustive one of the texts omitted by Ferguson, but it does include some obvious and frequentiy encountered titles.

It is impossible in a work of this nature to subject each text to the kind of intensive study carried out, for example, by Professor Soper on Kuo Jo-hsï's T'u-hua chien-wen chih. In my reviews, I have tended to devote greater space to the more important texts, and to be especially severe in my criticism of the more pretentious compilations. 
Although I tried to arrive at my own assessment of each text, Shu hua shu-lu chieh-t'i and Ssu-pu tsungIu i-shu pien were inevitably much consulted. I would like to express my appreciation of the assistance of Dr. K.T. Wu and his staff of the orientalia Division, Library of Congress; of Miss Jean Finch of the Stanford University Art Library; of the Harvard-Yenching Institute Iibrary; and of the University of Chicago Library. A number of elusive texts were located with the help of Sewell oertling, Celia Riely, Lothar Ledderose, and Marilyn Fu. Mr. Wang Nan-p'ing supplied the dates of two modern collectors. The manuscript was read by Mr. Wan Wei-ying, Head of the Asia Library, University of Michigan, who made a number of suggestions for improvement. Bibliographical problems were solved with the help of Celia $\mathrm{Hu}$, Assistant Librarian at the Freer Gallery; she also had the onerous task of checking two typescripts. Throughout the preparation of the Annotated Bibliography, Thomas Lawton was of assistance in ways too numerous to record; to him I owe a special debt. But for his repeated assurances that the project was worth finishing, I would surely have at some exasperated moment consigned the half-typed script to the Potomac.

Hin-cheung Love11 Freer Gallery of Art September, 1973 
List of Abbreviations

CPTSTS Chih-pu-tsu-chai ts'ung-shu 知示足変菐畫。 (Compiled by Pao T'ing-po 魯梃博; preface dated 1776. 1882 edition).

CSSHSP Chang shih shu hua ssu piao 張氏妻畫四表. (1908 edition).

GMS Gunnar Martins Samling av Kinesisk och Japansk Litteratur. (Stockholm, 1947).

HFLPC Han-fen-1ou pi-chi 选共梙秘笈. (Compiled 1916-26).

$\mathrm{HH}$

Han hai 逯海. (Compiled by Li Tiao-yian 李調文; preface dated 1782. 1882 edition).

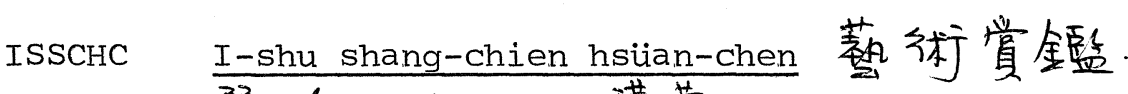

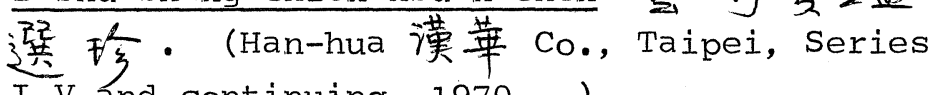
$\mathrm{I}-\mathrm{V}$ and continuing, 1970- ).

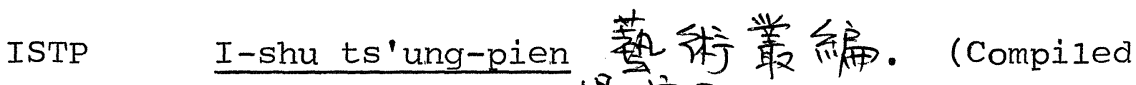
by Yang Chia-10 㛫永㗯, Taipei, preface 1962).

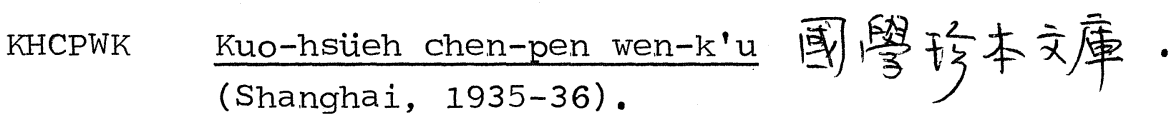

MTISCWCHK Ming-tai i-shu-chia wen-chi hui-k'an 明仿

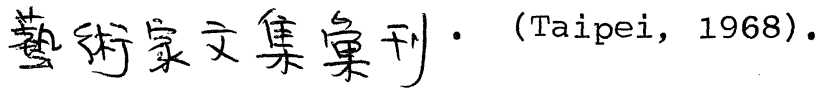


MSTS

Mei-shu ts'ung-shu 美術善書・ (Compiled by Teng Shih 锫赛 and Huang Pin-hung 番夏工，1912-36. Reprint of the 1947 enlarged edition, Taipei, n.d.).

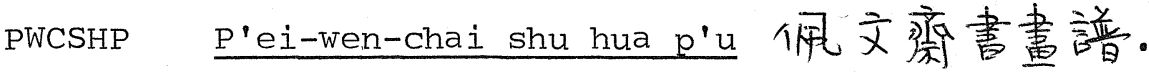
(Compiled 1708). See entry 51.

SKCS

ssu-k'u ch'uian-shu 业庫全毫・ ("Complete Library in Four Branches of Literature", compiled by order of the Ch'ien-lung emperor, 1773-85)。

SHCSTMTY Ssu-k'u ch'uian-shu tsung-mu t'i-yao 四㡽全書 会圆目提要. (Reviews of the 3,450 tities included in, and the 6,780 titles excluded from, SKCS, 1781).

SITS

Sung-Iin ts'ung-shu 松数丵意・(Compiled by Wu Ch'ang-shou 吴昌綬, 1917-18)。

TSCC Ts'ung-shu chi-ch'eng 丵意集成。(Commercial Press, Shanghai, 1935-37).

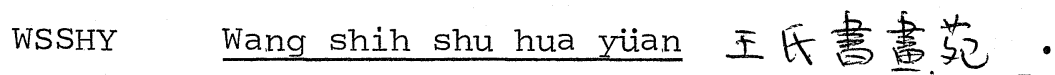
(Compiled by Wang Shih-chen 王世首 [died 1590] with supplement compiled by Chan Chingfeng 噟量闻 in 1590; 1922 edition)。 
1. P'ei Hsiao-yiian 裴孝源, Chen-kuan kung ssu hua shih 真整胃公私畫史. Preface dated 639 . 1 chiian. (Ferguson, 9, 12). MSTS, vol. 7, II/3, and ISTP, Vol. 8, no. 57, both based on SKCS.

Little is known about P'ei Hsiao-yuian except that he lived in the first half of the seventh century and that his official title was Chung-shu she-jen 中書舍人 (Drafting Official of the Secretariat). The "Chen-kuan" in the title of the text refers to the fact that it was compiled sometime during that reign, 627-650 A.D. In the SkCS text, there is a preface dated the thirteenth year of Chen-kuan, corresponding to 639 A.D. The dated preface is not included in either the MSTS or the ISTP edition, but is referred to in the SKCSTMTY review which appears in both.

Chen-kuan kung ssu hua shih is the earliest extant catalogue of paintings. It comprises the titles of 293 paintings, 281 of which are grouped under 53 artists, and 12 are anonymous. They range from Chin $\frac{\overline{4}}{\theta}$ to T'ang. Following this is a list of 47 temples in different cities with frescoes by known artists. The vast majority of the 293 paintings were from the Sui imperial collection.

Although there is very little information apart from the titles of the paintings, what little there is is of considerable interest. In a few instances, some imperial seals and colophons are noted. Under Lu T'anwei 陸探微, there are two groups of paintings, one of which $\mathrm{P}$ 'ei considered genuine, the other he considered doubtful despite their traditional attri- 
bution. Therein lies the first attempt at authentication in extant painting catalogues.

For a discussion of the problems of this text, see the review in SKCSTMTY as given in MSTS and ISTP.

2. Kuo Jo-hsiu 郭若虚, T'u-hua chien-wen chih

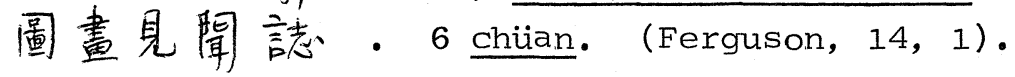
ISTP, Vo1. 10, no. 66 .

Kuo Jo-hsiu was a minor court official at the Northern Sung capital of $K^{\prime}$ ai-feng. He was active in the middle decades of the 11 th century but his exact dates are not known. In his preface to T'u-hua chienwen chih, he relates how his grandfather and his father were enthusiastic collectors of painting and calligraphy, and although the collection was dispersed after the father's death, Kuo Jo-hsii tried and succeeded in some measure to reassemble the lost items. T'u-hua chien-wen chih is one of the standard early histories of painting, and on internal evidence may be dated to the late 1070's.

Chiian 1 is devoted to discussions of various general aspects of painting. In chian 2-4, Kuo Jo-hsii lists and discusses 291 artists from the late T'ang to his own time. Thus, T'u-hua chien-wen chih can be used as a sequel to Chang Yen-yiian's Li-tai ming-hua chi ( $\underline{q} \cdot \underline{v}$. as it covers the very vital 200 years between that text and Teng Ch'un's Hua chi ( $\left.\underline{q} \cdot \underline{v}_{\cdot}\right)$. Chijan 5 and 6 consist of 27 and 32 accounts of artists or we11-known themes, the earliest going as far back as the 7 th century and the latest touch upon events which took place in the 1070's. 
The 291 artists discussed in chian 2-4 are arranged chronological1y: 1ate T'ang, 27; Five Dynasties, 91; and Sung, 173. The last group is further divided into painters who were emperors, princes and high officials; figure and portrait painters; landscape painters; painters of birds and flowers; and miscellaneous. Each entry gives a short biography and a brief discussion of the artist's style, and notes, by title, a few of his works.

For a thorough study and translation into English of T'u-hua chien-wen chih, see Alexander Coburn Soper, Kuo Jo-hsï's Experiences in Painting (Washington, D.C., 1951).

3. Liu Tao-ch'un 㩔道醇, Sheng-ch'ao ming-hua p'ing 埕朝名畫評, sometimes referred to as Sungch'ao ming-hua p'ing 宋朝名覀評, or Pen-ch'ao ming-hua p'ing 本朝名書評 - 3 chiian. (Ferguson, 13, 3). ISSCHC facsimile reprint of the 1908 edition (1972).

Iiu Tao-ch'un's exact dates are not known. He lived in the 11th century and was probably a fairly close contemporary of Kuo Jo-hsii $\left(\underline{q} \cdot \underline{v}_{\cdot}\right)$. His other compilation, Wu-tai ming-hua pu-i $\left(\underline{q} \cdot \underline{v}_{\cdot}\right)$, has a preface dated 1060.

Sheng-ch'ao ming-hua p'ing discusses 110 painters of the early Northern Sung dynasty. They are arranged into groups according to their specialities: figure painting; landscape; animals; birds and flowers; gods and demons; and architectural painting. Within each group, the painters are graded into the "inspired", the "excellent", or the "competent" class. For each artist, there is a biography followed by a critical appraisal of his work. 
4. Mi Fei 米芇, Hua shih 畫史. 1 chian. (Ferguson, 12, 4). MSTS, Vol. 10, II/9; ISTP, Vol. 10, no. 68 .

Mi Fei, the famous painter, calligrapher and critic, 1ived from 1051 to 1107. In his undated preface to Hua shih, he describes himself as an old man, and the year 1100 A.D. may be proposed as a very approximate date for its compilation.

Despite its concise title, Hua shih is not a history of painting. The work does begin with observations on painters and paintings, arranged according to dynasty, beginning with the Chin $\frac{\overline{4}}{\theta}$. But the system soon breaks down. In the rest of the text, critical comments on paintings, both in his own collection and in other people's collections, are interspersed with comments on such related topics as silk, mounting, storage, as well as with occasional forays into such irrelevant topics as old costumes, meteorology and phonetics. However, the reader who is prepared to put up with the poor organization of the book is amply rewarded. Mi Fei's astuteness and independence as critic and his concern for the authenticity of paintings make his statements on the painters very important.

For a complete transiation of Hua shih into French, see Nicole Vandier-Nicolas, Le Houa-che de Mi Fou (Paris, 1964).

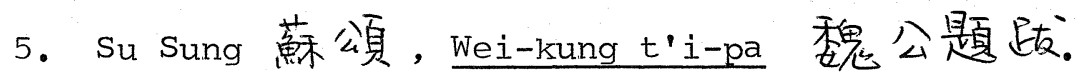
1 chuian. (Ferguson, 18, 1). ISTP, Vol. 22, no. 174. 
Su Sung (1020-1101) was an official and scholar. Wei-kung t'i-pa, culled from his collected works by the Ming bibliophile and editor Mao Chin 毛玄 (15991659), Consists of Colophons by Su on four paintings and eleven pieces of calligraphy.

6. Li Chih-i 李之傤, Ku-ch'it'i-pa 姑慀是夏跋。 2 chuian. (Ferguson, 8, 3). TSCC, no. 1593. [Harvard-Yenching].

Li Chih-i was a Northern Sung scholar roughly contemporary with Su Shih 蘇輚(1036-1101). Ku-Ch'i t'i-pa consists of his colophons on one painting and 86 pieces of calligraphy.

7. Tung Yu 重迫, Kuang-ch'uan hua pa 廣州畫跤・ 6 chïan. (Ferguson, 15, 2). WSSHY, chiian 3 and 4. [Freer].

Tung Yu was a late Northern Sung scholar active in the late 11th and early 12th century. Kuang-ch'uan huapa consists of colophons written by him on 136 paintings.

Many of the titles are of important paintings. However, Tung Yu was a scholar rather than a connoisseur, and the colophons were merely literary exercises. He took the subject matter as a point of departure for essays, and said little of value or interest about the artists and the paintings.

According to Hirth (Scraps from a Collector's Note Book, Leiden, 1905, pp. 113-14, the WSSHY text of Kuangch'uan hua pa is incomplete. 
8. Chuieh-fan Te-hung 叠钝德洪, Shih-men t'i-pa 石昒影跤 2 chüan. (Ferguson, 5, 6). ISTP, vol. 22 , no. 180 .

Shih-men t'i-pa records the colophons written by the monk Chiieh-fan Te-hung (1071-1128) on thirteen paintings and 100 pieces of calligraphy. The colophons embody Chan thoughts and sentiments, but virtual1y no information on the paintings. The work was edited by the 17th century bibliophile Mao Chin 毛晾.

9. Hsian-ho hua p'u 宣和畫譜. Preface dated 1120 . 20 chiian. (Ferguson, 9, 6). ISTP, Vol. 9, no. 65.

This is the catalogue of the paintings in the imperial collection of the Northern Sung emperor Huitsung 徽宗 (reigned 1101-26). The preface is dated the keng-tzu year of the Hsian-ho era, corresponding to 1120. Various compilers have been postulated, including Mi Fei and even Hui-tsung himself, but for none is the evidence conclusive.

A total of 6,396 paintings attributed to 231 artists, ranging from the Three Kingdoms period to Sung, are recorded. The material is divided into ten categories: (a) Buddhist and Taoist subjects (chuian 1-4); (b) human figures (chiian 5-7); (c) architecture (chuian 8); (d) foreigners (chiian 8); (e) dragons and fish (chuian 9); (f) 1andscape (chian 10-12); (g) anima1s (chiian 13); (h) birds and flowers (chiian 15-19);

(i) bamboo (chiian 20); and (j) vegetables (chian 20). 
Each category begins with an introductory section, following which the artists are arranged chronologically. For each artist, there is a biography, followed by a list of his paintings in the imperial collection. These biographies became a valuable source for later books on painting. The paintings are regrettably listed by title only and there is no other information pertaining to them.

The number of chiian devoted to the different categories do give a rough indication of their popularity and relative importance in court circles in the early 12 th century. But the organization of Hsian-ho hua p'u has its drawbacks. Cognizance is not given to the fact that a number of artists produced more than one type of painting. Once an artist is classified as of a certain category, all his paintings are listed in that category regardiess of subject matter. Ku K'aichih is in the "Buddhist and Taoist" category, and consequently his paintings on secular subjects are grouped with his Buddhist works. Similarly, Li Kung-lin, who comes under "human figures", has his Buddhist and Taoist paintings grouped with his secular figure paintings.

10. Teng Ch'un 登椿, "Ming-hsin chüeh-p'in 銘心 縃品"。(Ferguson, 14,4). PWCSHP, chiian 97.

"Ming-hsin chüeh-p'in" is chuian 8 of Hua chi 畫繼 (preface dated 1167), a work in ten chuian by Teng Ch'un in which he sets out to provide a sequel to Chang Yenyiian's Li-tai ming-hua chi ( 847 A.D.) and Kuo Jo-hsii's T'u-hua chien-wen chih (1070's) (qq. 
Chüan 8 is a list of 146 paintings in 37 collections which Teng Ch'un had seen; they range from the T'ang to the Sung. He stated that he had seen many more paintings but selected only the best for recording. Unfortunately they are listed by title only. The 1ist is incorporated into $\mathrm{p}^{\prime} e i-w e n-c h a i$ shu hua $p^{\prime} u\left(\underline{q} \cdot \underline{v}_{\bullet}\right)$, chian 97.

For a discussion of Teng Ch'un's Hua chi, see Robert J. Maeda, Two Twelfth Century Texts on Chinese Painting (Michigan Papers in Chinese Studies, no. 8, 1970).

11. Yang Wang-hsiu 棉王休, Sung Chung-hsing-
kuan-ko ch'u-ts'ang t'u-hua chi 宋中䀧館䧄 信者藏置畫記・ 1199 A.D. 1 chian. (Ferguson, 7, 3). MSTS, Vol. 18, IV/5; ISTP, vol. 10, no. 73 .

At the end of the catalogue there is a postscript dated 1210 stating that it was compiled in 1199 by Yang Wang-hsiu (1135-1200). The short preface states: "Paintings, 187 items. The Court continues the policy of [accepting paintings as tokens of] allegiance. These paintings are combined with the 911 scrolls and two albums from the old collection formerly recorded. They are here recorded, with the [artists] names appended."

The "old collection" and the "former catalogue" do not refer to Hui-tsung's collection recorded in Hsianho hua $p^{\prime} u(\underline{q} . \underline{v}$.$) ; hardly any of the titles there are$ duplicated by those in Sung Chung-hsing-kuan-ko ch'u 
ts'ang t'u-hua chi. Rather, they refer to the Southern Sung imperial collection, a list of which, entitled Piko hua mu 秘諊畫目, was compiled early in that dynasty. Much of the Northern Sung imperial collection was lost during the sack of K'ai-feng by the Chin Tartars in 1126. Kao-tsung (reigned 1127-62), the first of the Southern Sung emperors, is said to have made a serious effort to recover some of the lost paintings and to secure others, thus re-establishing another imperial collection.

In his Shu hua shu-lu chieh-t'i pu chia-pien

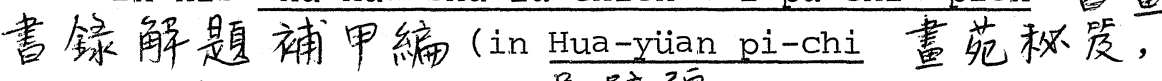
pp. 2b-4a), Wu Pi-chiang 吴辟疆 puts forward cogent reasons for concluding that Pi-ko hua mu was compiled in the Shao-hsing era (1131-62). The list does not appear to have survived, presumably because its contents was incorporated into the 1199 catalogue. But a breakdown of the total of the 911 scrolls and two albums from the "old catalogue" into different categories of painting is recorded in Ch'en K'uei's 陣臨 (1128-1203) Nan-Sung kuan-ko 1u 南宋館降睩, chuian 4 (Wu-1in chang-ku 武林掌故, Taipei, 1967, p. 2728). Ch'en K'uei was the compiler of Sung Chung-hsing-kuan-ko ch'u-ts'ang shu mu 宋中舆館閣信藏書目・The two companion lists of paintings and calligraphy are preserved in Nan-Sung kuan-ko hsui-1u 南宋飡䧄贖録, chuian 3 (Wu-1in chang-ku, pp. 2765-72).

The 1, 100 items in Sung Chung-hsing-kuan-ko ch'uts'ang t'u-hua chi are divided into the following categories: (1) paintings by Hui-tsung; (2) paintings bearing colophons by Hui-tsung; (3) Buddhist paintings; 
(4) sages; (5) demons; (6) secular figures; (7) landscape; (8) flowers; (9) animals; and (10) insects. Within each of the categories (3) to (10), paintings are grouped by artists chronologically, followed by anonymous paintings. In categories (1) and (2), there are notations recording Hui-tsung's inscriptions and colophons.

The intrinsic interest and importance of this text are self-evident.

12. Chu Hsi 朱喜, Hui-an t'i-pa 晦庵影跂. 3 chïan. (Ferguson, 11, 2). ISTP, Vol. 23, no. 183.

Hui-an t'i-pa records colophons on five paintings and 208 pieces of calligraphy by Chu Hsi (1130-1200), the eminent neo-Confucianist philosopher. The works was edited by Mao Chin ( $\underline{q} \cdot \underline{v} \cdot)$.

13. Ch'en Fu-liang 陳傅良, Chih-chai t'i-pa 止率 是自咙. 2 chuian. (Ferguson, 4, 4). ISTP, Vol. 23, no. 184 .

Ch'en Fu-liang (1141-1207) was a scholar and official, but not, judging from Chih-chai t'i-pa, a connoisseur of painting. Only nine of the 54 colophons recorded are on paintings, and the remarks are inconsequential.

14. Yeh Shih 菜適, Shui-hsin t'i-pa 水心题跂・ 1 chiian. (Ferguson, 4, 5). ISTP, vo1. 23, no. 185. 
Yeh Shih (1150-1223) was a scholar and official. The inclusion of Shui-hsin t'i-pa in Ferguson's bibliography is puzzling. Only three of the 55 colophons and encomiums were on paintings. The three paintings are not identified by artists, nor do they seem to be entered in the "Anonymous" section of Ii-tai chu-lu huamu. The work was edited by Mao Chin $(\underline{q} \cdot \underline{v} \cdot)$.

15. Chou Mi 周密, Yiin-yen kuo-yen 1u 雲烟週眼濌. 2 chuian. (Ferguson, 12, 11). MSTS, Vol. 6, II/2; ISTP, Vol. 17, no. 152 .

Chou Mi (1232-ca. 1308), scholar, poet and connoisseur, was an important figure of the period of late Southern Sung to early Yian. Yün-yen kuo-yen Iu is a catalogue of the paintings, calligraphy, bronzes, jades, ceramics and musical instruments in 45 collections which he had seen. The title is an allusion to an essay by Su Shih in which he compares old paintings to clouds which drift before the eyes.

Paintings and calligraphy constitute the majority of the items recorded. The entries for the paintings vary greatly in length. Some are merely titles while others record approximate dimensions and transcribe colophons and seals. This is something of an innovation. We would naturally wish for a more consistent treatment of al1 the paintings and for some critical comments from such an eminent connoisseur, but at that relatively early date, the cataloguing of paintings was still in its infancy. 
16. T'ang Yuin-mo 晹允謨, Yïn-yen kuo-yen hsui-1u

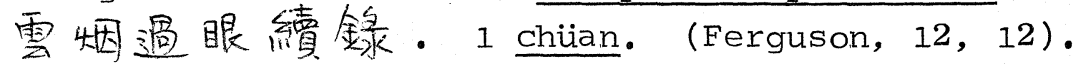
MSTS, Vol. 6, II/2; ISTP, Vol. 17, no. 153.

T'ang Yin-mo lived in the Yiian dynasty. The work is a sequel to Chou Mi's Yuin-yen kuo-yen Iu $\left(\underline{q} \cdot \underline{v}_{\cdot}\right)$, and follows it in organization. It records the paintings, bronzes, jades and other antiquities in four collections. The paintings are very few in number.

17. Yüan Chïeh 喜桷, "Lu-kuo Ta-chang-kung-chu t'u-hua chi 奥國大长公主圆畵記”。（Ferguson, 15, 3). PWCSHP, chiian 97.

This is a list of the titles of 35 paintings in the collection of the Yiian dynasty princess Hsiang-ko1a-chi 祥哥拉高 (Sengge Ragi). She was a niece and daughter-in-1aw of Tämur 鐡穆耳 (Ch'eng-tsung, reigned 1295-1307), the younger sister of Haisan 诲山 (Wu-tsung, reigned 1308-1311), and older sister of Ayurparibhadra 爱亩称拔力八羊 (Jen-tsung, reigned 1312-1320).

The list is excerpted from Ch'ing-jung-chu-shih chi 请容居士集 by Yuian Chuieh (1266-1327), and records how the Princess had gathered together some courtiers, feasted them, and asked them to write colophons on the paintings. The event took place in 1323.

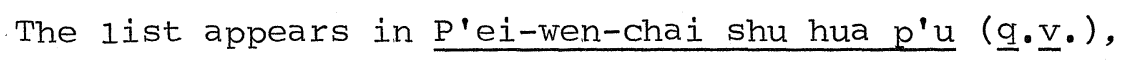
chiian 97. 
18. Chu Ts'un-1i 朱存理, Shan-hu mu-nan 珊瑚木難。 8 chiian. (Ferguson, 9, 8). ISSCHC facsimile reprint of the manuscript copy in the National Central Library (1970).

Chu Ts'un-1i (1444-1513) was a scholar and connoisseur, and he was friendly with shen Chou 谈围 and his circle. Shan-hu mu-nan is a record of the inscriptions and colophons on the paintings and calligraphy he had seen. Often he would state where he had seen the painting or calligraphy, or from where he had borrowed it to transcribe the colophons. There is no other information on the paintings.

The arrangement of the text leaves much to be desired. Paintings and calligraphy are interspersed, and there is no chronological order. The value of the text lies in the importance given to inscriptions and colophons, which constituted something of an innovation and became standard practice in many subsequent catalogues.

19. $\mathrm{Tu} \mathrm{Mu}$ 都穆, Yui-i pien 要意編・1 chuian. (Ferguson, 12, 1). MSTS, Vol. 6, II/1; ISTP, vol. 17, no. 155 .

Tu Mu (1458-1525) was a noted scholar and connoisseur in Suchou, and he was friendly with Shen Chou and such members of his circle as Liu Chieh 鹤王 and $W u$ K'uan 吴䆓. Yui-i pien consists of notes on 60 paintings and some calligraphy which he had seen in various collections. 
The material is arranged in random fashion and the entries are not standardized. Some paintings are listed by title only while others have information on colophons, seals and pedigree. The comments are interesting because of the circle in which $\mathrm{Tu}$ Mu moved and because some of the paintings are important.

20. Hua Hsia 尊, "Hua shih Chen-shang-chai fu chu

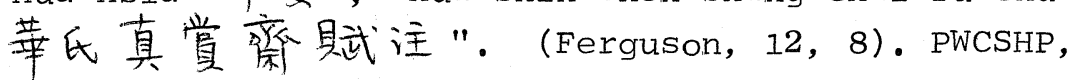
chiian 98 .

Hua Hsia (born ca. 1498, chin-shih 1544) was a collector and connoisseur. "Hua shih Chen-shang-chai fu chu" is a short list of 14 paintings ranging from the T'ang to the Yian in his collection. The 1ist appears in $\mathrm{p}^{\prime} e i-w e n-c h a i$ shu hua p'u $\left(\underline{q} \cdot \underline{V_{\bullet}}\right)$, chijan 98.

21. Wen Chia 文喜, Ch'ien-shan-t'ang shu hua chi 鈐山堂畫畫記. Preface dated 1569.1 chiian. (Ferguson, 12, 10). MSTS, Vol. 8, II/6; ISTP, vol. 17, no. 156.

At the end of the work is a postscript by wen Chia (1501-83) dated 1569 stating that Ch'ien-shan-t'ang shu hua chi is a list of the paintings and calligraphy confiscated from Yen Sung 橄高 (1480-1565).

Grand Secretary from 1542 to 1562, Yen Sung was a great favourite of the Chia-ching emperor and wielded immense power. Towards the end of his life, a combination of forces brought about his downfall. He came 
under fierce attack from his enemies, was dismissed from office, and degraded to the status of a commoner. One of the accusations brought against him was the inordinate tribute he exacted for favours, and the booty he amassed was all confiscated on his dismissal from office.

In his postscript Wen Chia states: "In the fifth month of the $i$-ch'ou year in the reign of Chia-ching [1565], Mr. Ho Pin-yai 何䆬涯 the t'i-hsuieh 提留 asked me to go over the confiscated paintings and calligraphy from Yen's old residence at Fen-i 分宜 and his new residences at Yuian-chou 袁州 and the provincial capital. It took three months for me to go through these and even then I could no more than glance at them cursorily. Recently while sorting my papers, I came across the 1ist, and so I made a catalogue with some notations....Wen Chia."

Because of his wealth and power, Yen Sung was indeed able to amass a large and very important collection of painting and calligraphy. The paintings, occupying the second half of the catalogue, are arranged chronologically and they range from Chin $\frac{\bar{y}_{1}}{6}$ to Ming. Many of the paintings are listed by title only, but others have brief comments comparing them to other versions known to the compiler. For these reasons, the catalogue is of considerable interest despite the fact that it could be far more informative. 


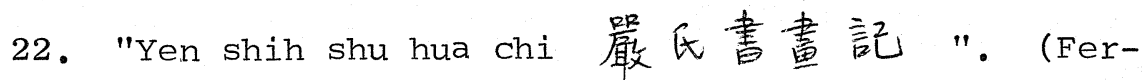
guson, 20, 1). PWCSHP, chiian 98.

This is a list of the paintings and calligraphy in the collection of Yen Sung ( $\underline{q} \cdot \underline{v}$.$) . The paintings$ are listed by artist and title only. Culled from Wen Chia's Ch'ien-shan-t'ang shu hua chi ( $\left.\underline{q}_{\cdot} \underline{v}_{\bullet}\right)$, the list first appeared in Shan-hu-wang hua $1 \mathrm{u}$ ( $\underline{\mathrm{q}} \cdot \underline{\mathrm{V}} \cdot)$, chuian 23, and was later incorporated into Shih-ku-t'ang shu hua hui-k'ao $(\underline{q} \cdot \underline{v} \cdot)$, chuian 2 , and p'ei-wen-chai shu $^{\prime}$ hua p'u $\left(\underline{q} \cdot \underline{v}_{\cdot}\right)$, chiian 98.

23. Chou Shih-1in 周石林, T'ien-shui ping-shan Iu 天水冰山铭水 1 chian. (Ferguson, 4, 3). CPTCTS, nos. 108-112. [Freer].

Although this work bears the name of Chou ShihIin, an early Ch'ing man, as its compiler, it is based on a manuscript copy of Ming date. The compilation consists of a list of all of Yen Sung's $\left(\underline{q} \cdot \underline{v}_{\bullet}\right)$ properties, as distinct from Wen-chia's Ch'ien-shan-t'ang shu hua $1 \mathrm{u}\left(\underline{\mathrm{q}} \cdot \underline{\mathrm{v}}_{\bullet}\right)$ which lists Yen Sung's paintings and calligraphy only.

24. Ho Liang-chuin 何良俊, "Shu hua ming-hsin 1u

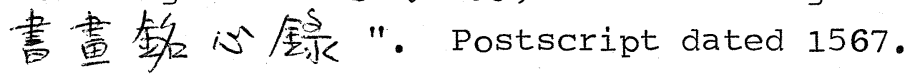
(Ferguson, 10, 4). PWCSHP, chiian 98.

This short text is attributed to the Ming scholar Ho Liang-chiin who was active in the Chia-ching period. His exact dates are not known, but his younger brother, 
Ho Liang-fu 何良傅, lived from 1509 to 1562 . "Shu hua ming-hsin Iu" does not exist as an independent work, but appears in $\underline{p}^{\prime} e i-w e n-c h a i$ shu hua $p^{\prime} u(\underline{q} \cdot \underline{v} \cdot)$, chuian 98, as well as in $T^{\prime} i e h-w a n g ~ s h a n-h u ~\left(\underline{q} . \underline{V}_{.}\right.$, No. 63), which is a questionable text. These versions differ considerably. In the latter version, there is a preface dated 1556 and a postscript dated 1567.

The text records several dozen paintings of Yian and early Ming date seen in four collections. Many of the entries contain descriptions of the paintings and critical comments. Occasionally approximate dimensions are given and important colophons noted but not transcribed.

25. Wang Shih-chen 王世真, Yen-chou-Shan-jen kao 命州山人稿； 176 chuian. Yen-chou-shan-jen hsii-kao 弇州山人續稿; 207 chiian. (Ferguson, 9, 7). 1577 edition and Wan-1i edition respectively. [Library of Congress].

Yen-chou-shan-jen kao and hsï-kao are a collection of the writings of Wang Shih-chen (1526-90), the eminent scholar, bibliophile and connoisseur.

Only chüan 137 and 138 in kao and chiian 168-70 in hsii-kao need concern us. In these five chiian are recorded colophons written by Wang Shih-chen on 183 paintings, ranging from T'ang to Ming. They contain interesting comments of a critical and scholarly nature; there is no other information on the paintings. Many of the paintings were important ones and some of them are still extant. 
26. Wang Shih-chen 王世颠, "Wang Shih-chen Erh-ya-1ou so-ts'ang ming-hua王世真䨋雅棲所藏名畫" (Ferguson, 4, 6). PWCSHP, chïan 98.

This is a list of the paintings in the collection of Wang Shih-chen (1526-1590), culled from his Yen-choushan-jen kao $(\underline{q} \cdot \underline{v}$.$) . The list has little information$ apart from the titles of the paintings.

The list first appeared in this form in Shan-hu-wang hua lu (q..$\underline{v}$.$) , chiian 23. It was later incorporated into$ Shih-ku-t'ang shu hua hui-k'ao (q. $\left.\underline{v}_{\cdot}\right)$, chian 2 , and into $\underline{p^{\prime} e i-w e n-c h a i}$ shu hua p'u (q. $\left.\underline{v}^{\prime}\right)$, chiuan 98.

27. Wang Shih-mou 王世榇, "Wang Shih-mou Tan-pu hua

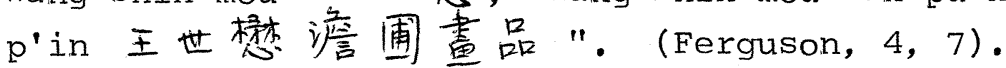
PWCSHP, chiian 98.

This is a list of the paintings in the collection of Wang Shih-chen's younger brother, Wang Shih-mou (15361588), culled from his Wang Feng-ch'ang chi 王奉常集. There is little information apart from titles of paintings.

The list first appeared in this form in Shan-hu-wang hua Iu $\left(\underline{q} . \underline{V}_{.}\right)$, chian 23. It was later incorporated into Shih-ku-t'ang shu hua hui-k'ao $\left(\underline{q} \cdot \underline{v}_{\cdot}\right)$, chiian 2 , and into $\underline{p^{\prime} e i-w e n-c h a i}$ shu hua $p^{\prime} u\left(\underline{q} . \underline{v}_{.}\right)$, chüan 98.

28. Chan Ching-feng 㢇景凰, Tung-t'u hsian-lan pien

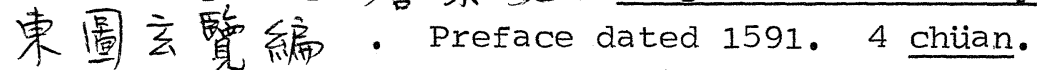
(Ferguson, 8, 5). MSTS, Vo1. 21, V/1; ISSCHC facsimile reprint of the manuscript copy in the National Central Library (1970). 
Chan Ching-feng (chii-jen 1567) was a painter, calligrapher and connoisseur active in the latter part of the 16th century. Tung-t'u hsian-lan pien, originally in 30 chüan, was never printed in its entirety. Only four of the 30 chian are concerned. with painting and calligraphy, the remaining chian consist of poems, essays and miscellaneous notes.

The four chiian have little organization. They record about 400 paintings and roughly the same number of calligraphy which Chan Ching-feng had seen in various collections. Prominent among these are those of Han Shih-neng, Wang Shih-chen and his brother Wang Shih-mou (qq. $\left.\underline{v}_{.}\right)$, who must have been his close contemporaries. The entries vary a great deal in length, from one or two lines to very detailed records, containing all the information which one is likely to want from a catalogue, as well as critical comments and anecdotes on how certain paintings changed hands.

This is an interesting text. Many of the paintings are important and some of them are still extant. It is not easy to use because there is no table of contents, but a leisurely perusal of the contents should be rewarding.

Ferguson did not adequately index the paintings recorded in this text. He used the incomplete list as it appears in $p^{\prime} e i-w e n-c h a i$ shu hua $p^{\prime} u(\underline{q} \cdot \underline{v} \cdot)$, chiian 99. Reference should therefore be made to either of the two editions here cited. The MSTS edition states that the manuscript copy on which it is based has a preface dated 1591. The same edition 
includes a supplement consisting of 38 colophons by Chan on paintings, culled from the other 26 chian of Tung-t'u hsian-lan pien. No such supplement is in the 1970 reprint.

29. Sun Kung 狝鑛, Shu hua pa pa 書畫跋跋. 3 chian, supplement 3 chiian. (Ferguson, 10, 3). ISSCHC facsimile reprint of the 1919 edition (1970).

Sun Kung (1542-1613) was a scholar and officia1. Shu hua pa pa is a commentary on some of the colophons by Wang Shih-chen (1526-1590) on paintings and cal1igraphy collected under the title of Yen-chou-shan-jen t'i-pa 命州山人题踮 and incorporated into Wang Shih-chen's miscellaneous writings in Yen-chou-shan-jen kao $(\underline{q} \cdot \underline{v} \cdot)$.

Shu hua pa pa existed in manuscript form unti1 1739 when it was printed for the first time under the auspices of two of Sun Kung's sixth generation descendants.

Sixty-five and 18 colophons on paintings are dealt with respectively in chian 3 and supplement chuian 3 ; the rest of the text is devoted to calligraphy. In each entry, Wang Shih-chen's colophon is transcribed in smal1 characters and Sun Kung's comments are in large characters. The text is of minimal interest. Far from subjecting Wang Shih-chen's pronouncements to a critical evaluation, which would have served a certain purpose since Wang Shih-chen was an important critic, the comments are inconsequential. 
30. Chu Ts'un-1i 朱存理 [sic., Chao Ch'i-mei

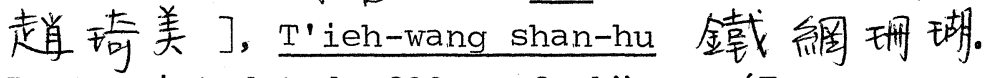
Postscript dated 1600. 16 chïan. (Ferguson, $20,3)$. ISSCHC facsimile reprint of manuscript copy in the National Central Library (1970).

This text was attributed to Chu Ts'un-1i (14441513) ( $\left.\underline{q} \cdot \underline{v}_{.}\right)$and still bears his name on the cover of the 1970 reprint. However, it is now generally agreed that the text was assembled by Chao Ch'i-mei (1563-1624), the well-known bibliophile and book collector.

Some editions of the text have a postscript dated 1600 by Chao Ch'i-mei stating that he had combined two anonymous texts borrowed from his friends Ch'in Ssu-lin 秦四底粦 and Chiao Hung 焦䇊 (1541-1620), rearranged the entries, and added some of his own. These editorial actions by Chao are deplorable as they render it impossible to sort out the contributions from the three different sources and arrive at a more correct dating of them. One or both of the anonymous texts could well have been from the early part of Ming, a1though it is impossible to say if they had any association with Chu Ts'un-1i.

Chïan 1-10 are on calligraphy, and chïan 11-16 on painting. So far as can be ascertained from the text, there is an unevenness in the quality of the paintings, as is understandable in a text of diverse origins. The majority of the paintings are Sung and Yian. Some of them are important paintings, and a number of them can be identified with extant paintings. The entries do not contain catalogue information such as dimensions, materials and seals, nor do they have descriptions of 
the paintings. As in Shan-hu mu-nan ( $\underline{q} \cdot \underline{v} \cdot)$, inscriptions and colophons are fully transcribed, and perhaps that is the reason why the text was attributed to Chu Ts'un-1i.

31. Chao Ch'i-mei 走当琦美, Mai-wang-kuan shu mu

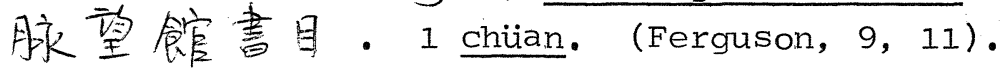
HFLPC, vi. [Harvard-Yenching].

Chao Ch'i-mei (1563-1624), was an avid book col1ector. Mai-wang-kuan shu mu is an inventory of his extensive library plus a list of about 35 paintings and various antiquities in his collection. The paintings bear attributions to T'ang through Ming, and are listed by title only.

32. Mao Wei 茅維, "Nan-yang ming-hua piao 南晋名 書表". (Ferguson, 9,4). PWCSHP, chïan 100 .

This list of 99 paintings by 47 artists in the collection of Han Shih-neng 暲世能 (1528-1598) appears in $\underline{p}^{\prime e} i-w e n-c h a i$ shu hua $p^{\prime} u\left(\underline{q} \cdot \underline{v}_{\cdot}\right)$, chijan 100. The compiler is given as Mao Wei, a scholar and poet who was active in the early 17th century. The 1ist is virtually the same as Chang Ch'ou's Nan-yang ming-hua piao $\left(\underline{q} \cdot \underline{v}_{\cdot}\right)$. The wording of the short preface suggests that it was lifted from Chang Ch'ou's longer preface and raises the possibility of the list itself being based on Chang Ch'ou's list rather than being compiled independentIy. 
33. Chang Ch'ou 張丑, Nan-yang ming-hua piao 南陽名畫表. (Ferguson, 9, 3). CSSHSP. [Freer].

This is a list of 95 paintings by 47 artists in the collection of Han Shih-neng 暲世能 (15281598), compiled sometime after his death. Han Shihneng was a high official whose last position before retirement was that of Vice Minister in the Board of Rites, and he was a most prominent collector, much admired by Chang Ch'ou.

The list is tabulated into columns: the vertical ones for the dynasties, from the period of the Three Kingdoms to the Yiian, and the horizontal ones for (a) Buddhist, Taoist and secular figure paintings, (b) landscape and architectural paintings, (c) flowers and birds, and (d) insects and fish. The paintings are listed by title, and many of them have a terse statement noting important colophons.

34. Chang Ch'ou 張丑, Ch'ing-ho shu hua piao

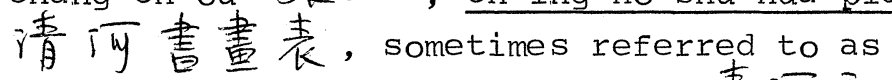
Ch'ing-ho pi-ch'ieh shu hua piao 清河秘逨 書畫表. 1 chiian. (Ferguson, 11, 3). CSSHSP. [Freer].

This is a list compiled by Chang Ch'ou (15771643) of 115 paintings and 49 pieces of calligraphy in the collections of eight members of six generations of his family. In his preface, Chang Ch'ou states that for generations his family had been closely associated 
with the foremost painters of their day. Great-grandfather Tzu-ho 子和 and his older brother Wei-ch'ing 維磨 are said to have been friendly with Shen Chou. Grandfather Yieh-chih 約之 and his younger brother Ch'eng-chih 誠之 were on intimate terms with wen Chengming, and this bond was sealed when the families were united by marriage in the next generation.

The material is tabulated into seven horizontal columns and eight vertical columns. Each of the horizontal columns designates a generation: (1) great-greatgrandfather Yüan-su 元素; (2) great-grandfather Tzuho and his older brother Wei-ch'ing; (3) grandfather Yiueh-chih and his younger brother $\mathrm{Ch}$ 'eng-chih; (4) father Mou-shih 茂實 ; (5) cousin I-sheng 以糹; (6) Chang Ch'ou himself; (7) nephew Tan-chia 言延喜品. The vertical columns are drawn up according to the dynasties, from Chin $\frac{\overline{4 s}}{\bar{\theta}}$ to Ming.

The value of this text is limited as the items are listed by title only.

35. Chang Ch'ou 張丑, Shu hua chien wen piao 書畫具阿袁, sometimes referred to as Fa-shu

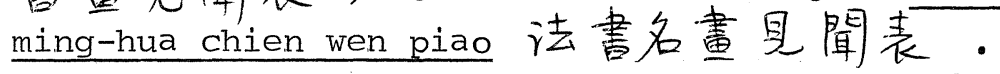
1 chuian. (Ferguson, 10, 2). CSSHSP. [Freer].

This is a list of 265 paintings and 188 pieces of calligraphy which Chang Ch'ou (1577-1643) had seen or heard about, compiled probably before Ch'ing-ho shu hua fang $(\underline{q} \cdot \underline{v}$.$) . The paintings range from the$ Six Dynasties to Ming, and are arranged chronologically with the calligraphy, but divided into two cate- 
gories, those which Chang $\mathrm{Ch}$ 'ou had seen and those which he only knew about. The works are listed by title only and there is no other information.

36. Chang Ch'ou 炜丑, Ch'ing-ho shu hua fang 诸河書意舫. Preface 1616. 12 chuian. (Ferguson, 11, 4). 1875 edition. [Freer].

Coming as he did from a family of collectors who were on friendly terms with artists and collectors of their time, Chang Ch'ou (1577-1643) ( $\left.\underline{q}_{\text {. }} \underline{\mathrm{V}}_{\mathbf{*}}\right)$ had the opportunity of seeing a large number of important paintings and calligraphy. Ch'ing-ho shu hua fang is a catalogue of a large number of paintings and calligraphy ranging from the Three Kingdoms period to Ming.

Unfortunately, the text is marred by many flaws. While it is understandable that Chang Ch'ou should include paintings he had not seen in an unpretentious list such as shu hua chien wen piao $\left(\underline{q} \cdot \underline{v}_{\cdot}\right)$, their inclusion in a text of much more serious intent is of very dubious value. The same fuzziness of purpose is probably responsible for inconsistencies in the organization, rendering the text difficult to use.

The broad scheme of the text is as follows. The material is arranged by period and within each period by individual painter or calligrapher. For each artist, Chang Ch'ou begins with an introductory section bringing together general information on him culled from his wide reading. Following this is a catalogue of the works he had seen or heard about. Chang Ch'ou 
would record when and in whose collection he saw a painting. There is no catalogue information such as dimensions, materials and description of the painting. Inscriptions and colophons are fully transcribed but seals are only infrequently recorded. In the cases where Chang Ch'ou had not seen the paintings, the transcriptions were drawn from texts. Almost always, an entry would be followed by quotations from earlier texts on the painting. Often at the end of a chiian, there would be supplements on various artists dealt with in the same chian, with information on additional paintings and lengthy quotations from Hsian-ho hua p'u $\left(\underline{q} \cdot \underline{v}_{.}\right)$, including all the titles by the artists listed there.

The inclusion of such texts as Mi Fei's Pao-chang tai-fang Iu 架章待訪録 and Wen Chia's Yen Shih shu hua chi (q.v..$)$ in the sections devoted to these artists is yet another proof that Chang Ch'ou's Ch'ingho shu hua fang is extremely ill-defined in purpose.

The defects apart, this text is interesting for its quotations on paintings from some early, relatively unknown, texts; for its full transcriptions of colophons on those paintings Chang $\mathrm{Ch}$ 'ou had actually seen; and for the occasional comments by Chang $\mathrm{Ch}^{\prime}$ ou on paintings and personalities.

37. Chang $\mathrm{Ch}$ 'ou 張业, Chen-chi jih $1 \mathrm{u}$ 真䠐日钌. 3 chüan. (Ferguson, 10, 7). 1918 edition. [Library of Congress]. 
According to Chang Ch'ou's preface, so many paintings and calligraphy were shown to him after he finished Ch'ing-ho shu hua fang ( $\underline{q} \cdot \underline{v} \cdot$ ) that he kept notes on some of them, and the result was Chenchi jih lu. As the title indicates, the text is in diary form recording the items in the order in which Chang saw them. Not every entry is dated, but the few dates which can be found are in correspondence with the $1620^{\prime} \mathrm{s}$, and the text can be assigned to that decade.

About 160 paintings and 130 pieces of calligraphy ranging from the Six Dynasties to the Ming are recorded in Chen-chi $j i h \mathrm{lu}$. The entries follow no fixed form and vary in length according to whether Chang Ch'ou found them interesting. Many entries are lengthy and contain transcriptions of colophons as well as record seals; they often end with a critical comment by Chang Ch'ou. The owners of many of the items are identified. Perusal of this text can be rewarding.

38. Li Jih-hua 李日華, Liu-yen-chai pi-chi 六硯率 篻記，4 chian; Liu-yen-chai erh-pi 六䃆栾二筆， 4 chuian; Liu-yen-chai san-pi 六硯率三筆，4 chüan. (Ferguson, 4, 2). KHCPWK. [Asia Library, University of Michigan].

Li Jih-hua (1565-1635) was a scholar and connoisseur. Liu-yen-chai pi-chi and its two sequels are a miscellany in the form of an informal diary recording 
events and thoughts on such diverse topics as Taoism, medicine, poetry and the arts as they occurred to him between the years 1624 and 1635 .

Much of the text is concerned with paintings and calligraphy which he saw, and these entries are often quite detailed, recording artist, title, subject matter and colophons. The book is also full of titbits of information of peripheral interest, such as the identification of persons and studios. It is the kind of text that would reward any casual browsing.

39. Tung $\mathrm{Ch}^{\prime} i-\mathrm{ch}^{\prime} \mathrm{ang}$ 容喜别集. 6 chuian. (Ferguson, 10, 1). MTISCWCHK facsimile reprint of the original edition in the National Central Library, vol. 14. [Freer].

Jung-t'ai pieh-chi is a sequel to Jung-t'ai chi 突喜集, a collection of the miscellaneous writings of Tung Ch'i-ch'ang (1555-1636). Both were compiled by his grandson Tung T'ing 重庭. Although the preface to Jung-t'ai pieh-chi has no date, its compilation is probably not much later than that of Jung-t'ai chi which has a preface by Ch'en Chi-ju $(\underline{q} \cdot \underline{v}$.$) dated 1630$.

Scattered in chiian 1, 2 and 6 are a number of colophons on paintings by Tung $\mathrm{Ch}^{\prime} \mathrm{i}$-ch'ang, some in his own collection and others seen by him. Since Tung Ch'i-ch'ang was such an eminent painter and critic, the statements he made on earlier painters are of extreme importance. There is no catalogue information of the usual sort, only critical comments. 
Instead of indexing all the titles of paintings discussed in pieh-chi, Ferguson lists only the few titles quoted in $\mathrm{p}^{\prime}$ ei-wen-chai shu hua $\mathrm{p}^{\prime} \mathrm{u}$ ( $\left.\underline{\mathrm{q}} \cdot \underline{\mathrm{v}}_{\cdot}\right)$, chian 100 and one or two other places in that anthology.

40. Tung Ch'i-ch'ang 董其昌, Hua-chan-shih sui-pi 鲁禅公随筆・1 chiian. (Ferguson, 12, 5). 1720 edition in ISTP, Vo1. 28, no. 252.

Hua-chan-shih sui-pi is a selection of the writings of Tung Ch'i-ch'ang (1555-1636), compiled by Yang Wu-pu 㛫無補 (died 1657). Very little material in this selection duplicates that in Jung-t'ai chi and pieh-chi $(\underline{q q} \cdot \underline{v}$.$) , and it is probable that the selection was made$ to supplement them.

There are 16 sections in Hua-chan-shih sui-pi. Ferguson uses only the abbreviated version of section 6 , entitred "Hua yiain 畫源", as given in P'ei-wenchai shu hua-p'u (q..$\left.\underline{v}_{.}\right)$, chiian 100, but reference should be made to the fuller original text. In it, Tung Ch'i-ch'ang discusses about 50 paintings, some in his collection and others he had seen. They are all important monuments.

Two other sections in Hua-chan-shih sui-pi are relevant to our purpose; they were not indexed by Ferguson. These are: section 7, entitled "T'i tzu hua 题自畫", which consists of 43 inscriptions on Tung Ch'i-ch'ang's own paintings; and section 8, entitled "P'ing chiu hua 評舊畫", which consists of 17 colophons by Tung on earlier paintings. 
41. Chang T'ai-chieh 張泰栺, Pao hui 1u 篗繒銥, sometimes referred to as Ssu-ch'ao

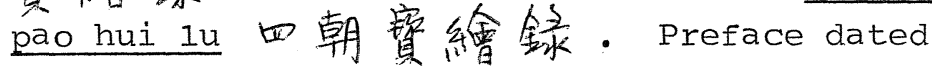
1633. 20 chiian. (Ferguson, 19, 2). ISSCHC facsimile reprint of the CPTCTS edition (1972).

Chang T'ai-chieh obtained his chin-shih degree in 1619. Apart from some general statements on paintings and certain painters in chijan 1, Pao hui 1u is a catalogue of several hundred paintings attributed to the foremost painters of the Six. Dynasties, the T'ang, the Sung and the Yian dynasties. Hence the "ssu-ch'ao" of the title. The probability of so many paintings by the best artists from the 5th to the 14 th century being genuine is very slight indeed, and one cannot help but be very sceptical of their authenticity. In Ch'ing-hsia-kuan Iun hua chiieh-chii $\left(\underline{q} \cdot \underline{V}_{\cdot}\right)$, Wu Hsiu baldIy states that Chang T'ai-chieh was an unscrupulous dealer and that all the paintings recorded in Pao hui $1 u$ were recent forgeries.

The entries record only inscriptions and colophons. Regardless of whether the paintings were genuine or not, the lack of such information as dimensions, materials, seals, and so on, makes the text hopelessly inadequate as a catalogue.

42. Yui Feng-ch'ing 有浲殿, Yui shih shu hua t'i-pa chi 有化書畫题跋記. Postscript dated 1633. 12 chiian. (Ferguson, 9, 13). ISSCHC facsimile reprint of manuscript copy in the National Central Library (1970). 
Yï Feng-ch'ing was a connoisseur active in the late Ming dynasty. In his postscript dated 1633, he relates how the book grew out of transcriptions he made over the years of inscriptions and colophons on paintings and calligraphy which belonged to his collector friends. Paintings and calligraphy are not put into separate categories, nor are they arranged in chronological order. They are presumably in the order in which Yü saw them.

The text is of limited value because it contains no more information on the paintings than selected inscriptions and colophons. Consequently it is difficult to be certain of the relationship between the paintings in the text and extant paintings with the same or similar tities.

In certain editions of this text, there is a supplement of twelve more chuian.

43. Ch'en Chi-ju 陳㽧儒, Ni ku 1u 妮古镓. 4 chuian. (Ferguson, 8, 2). MSTS, Vol. 5, I/10; ISTP, Vol. 29, no. 253.

Ch'en Chi-ju (1558-1639) was a late Ming painter, and a contemporary and close friend of Tung $\mathrm{Ch}^{\prime} \mathrm{i}$-ch'ang (q..$\left.{ }^{.}\right) . \quad \mathrm{Ni} \mathrm{ku} \mathrm{u} u$ is in the form of notes on paintings, calligraphy and other antiquities in his own and other people's collections. The notes, written in and about 1635, are in the order in which the objects were seen. Hence, the material is not well organized, and sometimes the same items are discussed in two different entries. 
There is no complete catalogue information on the paintings, and the comments are in the nature of a painter's opinions.

44. Wang $K^{\prime}$ o-yii 汪砢王, Shan-hu-wang hua 1u 珊瑚絪素镍. Preface dated 1643. 24 chuian, supplement 1 chiian. (Ferguson, 9, 9). 1916 edition. [Freer]. Chuian 23 appears under the title of Hua chii 喜據 in MSTS, vol. 6, II/1 and ISTP, Vol. 13, no. 106; chüan 24 appears under the title of Hua chi 雷繼 in MSTS, Vol. 6, II/1 and ISTP, Vol. 13, no. 105; the supplement appears under the title of Hua fa 轰法 in MSTS, Vol. 6, II/I and ISTP, Vol. 13, no. 107.

Wang $K^{\prime} \mathrm{o}$ yii (born 1587) came from a family with a long tradition of collecting. His father Wang Ai-ching 汪爱荆 was a contemporary and close friend of the eminent collector Hsiang Yian-pien 项元泫 (1525-90). Consequently, apart from inheriting his father's collection, Wang $K^{\prime} o-y i$ no doubt had the opportunity of seeing at least part of Hsiang's extraordinary collection.

Chiian 1-22 of Shan-hu-wang hua lu are devoted to recording the inscriptions and colophons on a large number of paintings, some in Wang's own collection, some seen by him, and others which he knew of from reading. Unfortunately, Wang does not give dimensions, nor information on materials and seals. The paintings range in date from the Six Dynasties to the Ming, and they are arranged chronologically, album leaves being relegated to chijan 19-22. 
Chiian 23 consists of a list of paintings in a number of famous collections in the Sung, Yian and Ming dynasties, compiled from various earlier texts. It is the source of many subsequent lists of this nature, such as that in Shih-ku-t'ang shu hua huik'ao, in Chu-chia ts'ang-hua pu and in P'ei-wen-chai shu hua p'u (qq. $\left.\underline{v}_{\cdot}\right)$. Chiian 24 consists of quotations from various writers on the theory of painting and a survey of the history of painting. The last chiian, the supplement, is a manual on painting, culled from earlier writings.

45. Chu Chih-ch'ih 朱之志, Chu Wo-an ts'ang shu hua mu 朱卧㟟藏畫畫目・ 1 chuian. (Ferguson, 6, 3). MSTS, Vol. 8, II/6; ISTP, Vol. 17, no. 157 .

The dates of Chu Chih-ch'ih's birth and death are not known. He is generally considered a Ming man, but there is evidence for his having lived into the Ch'ing dynasty. One entry in Chu Wo-an ts'ang shu hua mu refers to Wang To 王鐸 $(1592-1652)$ by his posthumous title, so that we can say that this text is no earlier than 1652 .

The text is little more than a list of the titles of the paintings and calligraphy in Chu Chih-ch'ih's collection. The only additional information is the mention of notable colophons.

In his Shu hua shu-1u chieh-t'i ( $\underline{q} \cdot \underline{v} \cdot$, chüan 6:16a), Yii Shao-sung questions the authenticity of this text on the basis of an entry for "a landscape by Ku T'ing-lin 
雇亭林 after Huang Kung-wang, with a colophon by Ch'en Chi-ju". Yü Shao-sung maintains that Ku T'inglin, whom he mistook for ku Yen-wu 雇萑苂武, a calligrapher who lived from 1613 to 1682, was much too junior to $\mathrm{Ch}^{\prime}$ en Chi-ju (1558-1639) in years to have a colophon by the eminent painter on his painting if he had indeed been able to produce a painting. However, Ku T'ing-lin was probably Ku Cheng-i 雇正誼, who was indeed a landscape painter and a contemporary of Ch'en Chi-ju. Both Ku Cheng-i and Ku Yen-wu had T'ing-lin as their hao.

46. Sun Ch'eng-tse 孫承䐾, Keng-tzu hsiao-hsia chi 庚子銷夏記. 1660 . 8 chiian. (Ferguson, 8, 4). ISSCHC facsimile reprint of the 1761 edition (1970).

Sun Ch'eng-tse (1592-1676) was a scholar and official who served under both the Ming and Ch'ing governments. Keng-tzu hsiao-hsia chi was written in his retirement in the summer of the keng-tzu year, corresponding to 1660 .

Chiuan 1-3 record Sun's collection of paintings and calligraphy ranging from the Six Dynasties to the Ming. Chuian 4-7 deal with pei, stone engravings of calligraphy, and t'ieh, reproductions of famous calligraphy. Chuian 8 records paintings and calligraphy in other people's collections which Sun had seen.

The text is weak on catalogue information and strong on critical comments and research. Sun Ch'eng- 
tse does not concern himself with such matters as measurements, materials, seals and colophons. He combines connoisseurship with research, and the entries consist of critical evaluation of the items and information on the artists' life and other works.

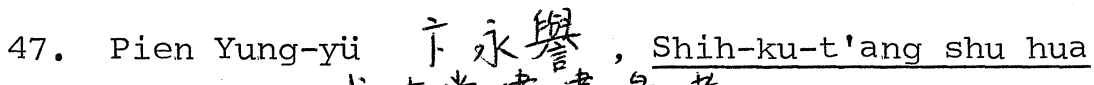
hui-kiao 武古堂寒畫害考. 1682.60 chian. (Ferguson, 6, 2). Facsimile reprint of the original K'ang-hsi edition (1921). [Freer]. Facsimile reprint of the 1921 reprint (Taipei, 1958).

Pien Yung-yii (1645-1712) was a senior official and from his youth was interested in painting and calligraphy. He knew many of the prominent collectors of his time and had the opportunity of studying many original masterpieces and making notes on what he saw.

While serving as Intendant of Couriers in Shantung in the years 1680-82, Pien Yung-yii compiled Shih-kut'ang shu hua hui-k'ao, an ambitious work which set out to be a more comprehensive text of painting and calligraphy than had hitherto been attempted. For this he consulted more than 130 books, collating the information on each item he 1isted. The work is in 60 chian, 30 of which are devoted to calligraphy and 30 to painting. For the latter, the books consulted number ninety.

Chiian 1 is an anthology of quotations on the theory of painting from various old texts on the subject. Chiian 2 records 82 famous collections, imperial and private, from the T'ang to Ming. Much of this information 
is taken verbatim from Shan-hu-wang hua lu ( $\underline{q} \cdot \underline{v}$.$) ,$ chiian 23. The paintings in the 82 collections are listed by title only. Chüan 3-7 record famous albums, and chiian 8-30 famous handscrolls and hanging scrolls, arranged under their artists, who are placed in a chronological sequence. For those items which Pien had actually seen, inscriptions and colophons are conscientiously transcribed and seals are fully recorded. Such catalogue information as dimensions, materials, subject matter and description of painting is terse and could be more fully and consistently given. These parts of the text are useful.

For those paintings which Pien had not seen, he would have a "wai-1u 外録" section in which he quotes from various sources where the paintings are recorded or discussed. Consequently, Shih-ku-t'ang is often used as an index to the books which Pien lists in his bibliography. As such, the text should be used with caution, as these quotations are not always judiciously chosen nor are they exhaustive in relaying the information in the books consulted.

A single example will suffice to demonstrate these shortcomings. In chian 8, Ku $\mathrm{K}^{\prime}$ ai-chih section, pp. 4b5b (1958 reprint, vol. 3, p. 351), the painting entitled Lo-shen t'u (Nymph of the Lo River) has in its entry two quotations. The second is a lengthy quotation from Kuo Ju-hsï's T'u-hua chien-wen chih ( $\underline{q} \cdot \underline{v} \cdot)$ which does not mention the Lo-shen $t^{\prime} u$. The quotation is therefore entirely irrelevant, and its presence may even mislead a casual reader into thinking that the Lo-shen $\underline{t^{\prime} u}$ is recorded in T'u-hua chien-wen chih as being in 
Ku K'ai-chih's oeuvre. In actual fact, the artist whose name is more firmly associated with the Lo-shen t'u in early texts is ssu-ma Chao 司焉昭 (299-325) who reigned as Chin Ming-ti $\frac{\overline{4}}{B}$ 明离 from 323 to 325. The two early texts which furnish this piece of evidence are P'ei Hsiao-yian's Chen-kuan kung ssu hua shih and Chang Yen-yian's Li-tai ming-hua chi (qq.V.). While both these texts are in Pien Yung-yï's extensive bibliography, only the former is quoted by him in the section on Chin Ming-ti (chüan 8; 1958 reprint, vol. 3, p. 348). The omission of latter reference, the absence of an entry for the Lo-shen t'u in its own right in the section on Chin Ming-ti, plus the misleading long quotation from $\mathrm{T}^{\prime} \mathrm{u}$-hua chien-wen chih in the $\mathrm{Ku} \mathrm{K}^{\prime} \mathrm{ai}-\mathrm{ch}$ ih section - these are tantamount to a gross distortion of the evidence. One reason for these errors of omission and commission may be that by Pien Yung-yii's time, the Lo-shen t'u was so firmly attributed to $\mathrm{Ku} \mathrm{K}^{\prime} \mathrm{ai}-$ chih that any evidence to the contrary would be too disturbing for comfort. And by so injudiciously using the textual evidence at his disposal, Pien further compounded the impression of a firm association of $\mathrm{Ku}$ K'ai-chih with the painting.

The conclusion must be that Shih-ku-t'ang shu hua hui-k'ao fails to fulfil its potential as Pien Yung-yii lacked the qualities of accuracy, thoroughness and truthfulness necessary for a compilation of this kind. The parts dealing with paintings which Pien had not seen can be used as a lead to some of the older texts, but the reader is urged to verify the sources rather than stop at Shih-ku-t'ang. 
48. Yiin Shou-p'ing 恽喜平, Nan-t'ien hua pa 南田畫咙 - 4 chiian. (Ferguson, 9, 1). MSTS, Vol. 18, LV/6; ISTP, Vol. 23, no. 198.

Yin Shou-p'ing (1633-1690) was one of the painters of the so-called orthodox school of the early Ch'ing dynasty. Nan-t'ien hua pa is a collection of the random thoughts of Yin Shou-p'ing on the painters and paintings of interest to him, assembled from his writings after his death. It throws more light on Yiu Shou-p'ing and the theories and practices of his school than on the paintings discussed.

Chiian 1 contains statements on the theory of painting. Chian 2 contains discussions of those painters from whom the early Ch'ing orthodox school traced its Iineage (Tung Yuian and Chu-jan, Huang Kung-wang and his contemporaries), as well as discussions of the members of the orthodox school of the early Ch'ing (the Four Wangs, etc.). This chiian a1so contains interesting anecdotal material on certain famous paintings by some of the artists discussed, such as the Fu-ch'un shan-chii t'u by Huang Kung-wang. Chiian 3 consists of descriptions and discussions of specific paintings. Chiian 4 consists of poems about painters and paintings.

49. Kao Shih-ch'i 高士奇, Chiang-ts'un hsiao-hsia Iu 江都销夏録・1693. 3 chiian. (Ferguson, 6, 5). ISSCHC facsimile reprint of the 1923 edition (1970). 
Kao Shih-ch'i (1645-1704) was a scholar, collector and a personal secretary to the $K^{\prime}$ ang-hsi emperor (reigned 1662-1722).

Completed in 1693, Chiang-ts'un hsiao-hsia 1u is a catalogue of the better paintings and calligraphy that Kao Shih-ch'i had seen in the three years preceding 1693, each of the three chiian being devoted to the items he saw in one year. Within each chian, the items are arranged in a chronological order, regardless of their format; paintings and calligraphy are not put into separate categories. They range from the Six Dynasties to the Ming, but exclude works by Tung Ch'ich'ang because "they are so important and so numerous that they merit a separate volume". Each entry contains such information as dimensions, materials, description of subject matter, artist's signature, seals and inscriptions, as well as other seals and colophons, including those by Kao Shih-ch'i.

Compared to such earlier catalogues as $\mathrm{T}^{\prime}$ ieh-wang

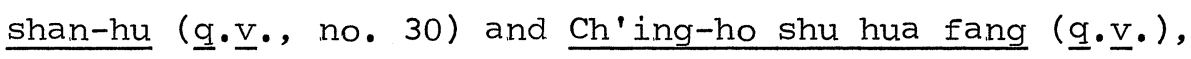
Kao Shih-ch'i's catalogue contains much fuller information and is more consistent. Compilers of many subsequent catalogues used it as their model, frankly acknowledging their debt to Kao. However, the commendable methodical approach is not matched by an equally high level of connoisseurship as the entries have no critical statements. 
50. Kao Shih-ch'i 高士奇, Chiang-ts'un shu hua mu 江村書亩目・1 chian. (Ferguson, 6, 4)。 MSTS, Vol. 24, V/8 (under the title of Kao Wen-k'o Kung shu hua chen ying mu 高文珞公書畫 真膺目 ); facsimile reprint of manuscript copy (Hong Kong, 1968). [Freer].

This work is a list of the paintings and calligraphy in the collection of Kao Shih-ch'i (1645-1704) $\left(\underline{q} \cdot \underline{v}_{.}\right)$. The manuscript copy on which the 1968 reprint is based has a postscript by Wu Hsi-ch'i 吴颌視 (1746-1818) stating that it was from the hand of Kao Shih-ch'i. But as Lo Chen-yui 羅振玉 (1865-1940) points out in his postscript to the first printed edition (Shanghai, 1924), the manuscript was actual1y from the hand of a descendant of Kao Shih-ch'i as he is referred to by his posthumous title Wen-k'o 文烙. Another reason why the manuscript was probably by a descendant is that there occur three times the "44th year of the reign of $\mathrm{K}$ 'ang-hsi", corresponding to 1705, the year after Kao Shih-ch'i's death. It would appear that Chiang-ts'un shu hua mu is a list written by one of Kao's descendants, copied from lists compiled by Kao in his lifetime.

The items number 534, approximately half of which are paintings and half calligraphy. They are divided into nine categories: (1) items to be presented to the emperor; (2) items to be given away as presents; (3) and (4) items without Kao's colophons, to be kept; (5) items of the divine category to be kept forever, calligraphy; (6) ditto, paintings; (7) items of superior quality with colophons by Kao; (8) items for private enjoyment; and (9) works by Tung Ch'i-Ch'ang. 
Each entry is listed by title, followed by one terse statement as to its authenticity and quality; occasionally an important colophon or title is noted. The price paid for each item is meticulously recorded. It is amusing to observe that the least expensive pieces are in categories (1) and (2). The lists were evidently compiled as personal memoranda and not meant for public consumption.

Despite the terseness of the entries, some of the paintings can be identified with extant works.

51. P'ei-wen-chai shu hua p'u 佩文宸素畫譜。 1708. 100 chiian. (Ferguson, 8, 1). Undated early edition printed from original blocks. [Freer]. Facsimile reprint of original edition (Taipei, 1969).

On November 24, 1705, the K'ang-hsi emperor (reigned 1662-1722) commissioned Wang Yuian-ch'i 王㢈衩 (1642-1715) and four other officials to compile a comprehensive work on calligraphy and painting. It was completed in 1708 and was printed under the title $\mathrm{P}^{\prime}$ ei-wen-chai shu hua $\mathrm{p}^{\prime} \mathrm{u}$, with a preface by the emperor.

A vast body of literature was combed for information on calligraphy and painting. The bibliography totals 1,844 titles, some of which were rare books or had not been printed before. In addition to all the available works dealing specifically with calligraphy and painting, the books consulted include classics, histories official, unofficial and local, biographies, 
many miscellanies, poetry, and even pharmacopoeias.

Forty-two of the 100 chiian are devoted to painting and the rest of the book to calligraphy. These are: chiian 11-18 (discussions of paintings as regards style, method, theory and grading); chiian 21 (emperors and consorts who were painters); chian 45-58 (biographies of painters); chiian 65-66 (anonymous paintings); chiian 67 (colophons on paintings by the $K^{\prime}$ ang-hsi emperor); chian 69 (colophons on paintings by emperors); chiian 81-87 (colophons on paintings by famous people); chuian 90 (the authentication of problematical paintings); and chuian 95-100 (famous collections of paintings).

The parts which Ferguson used for his index are chiian 81-87 and 95-100, and it is with these that we are most concerned. P'ei-wen-chai shu hua p'u is a very valuable anthology in many respects, but it is not the encyclopaedic compilation it set out to be. In the chuian which Ferguson used, the material has been taken from its sources in drastica $11 y$ abbreviated form. This is particularly true of chuian 95-100, where many of the lists of famous collections have been quite arbitrarily reduced. For a full documentation of any painting, the reader is urged to go to the original sources instead of relying on p'ei-wen-chai.

52. Yao Chi-heng 姚際恲, Hao-ku-t'ang shu hua chi 好古堂書畫記. Preface dated 1699. 2 chiian. Supplement, dated 1707. (Ferguson, 6, 1). MSTS, Vol. 14, III/8; ISTP, Vol. 14, no. 158. 
Yao Chi-heng (1647-after 1707) was a collector, bibliophile, and an outstanding textual critic of the classics. Hao-ku-t'ang shu hua chi is a catalogue of the calligraphy, paintings and miscellaneous curiosities in his collection, arranged in that order. There are about 100 paintings, ranging from the Five Dynasties to the Ming.

The entries are not standardized and vary a great deal in length. They do not give such catalogue information as measurements and materials, nor do they record all the colophons and seals. Yao Chi-heng selects those colophons and seals which he considers important for recording and discussion. His keenness as a critic is evident in such entries as the one on Tung Yiian's 董源 Hsiao-hsiang t'u 潰湘圆.

The usefulness of this catalogue is marred by the absence of a table of contents.

53. Chu I-tsun 朱亲首, P'u-shu-t'ing shu hua pa 曝書亭畫畫跤. 1 chuian. (Ferguson, 19, 3). MSTS, Vol. 5, I/9; ISTP, Vol. 25, no. 202 .

Chu I-tsun (1629-1709) was a distinguished historian, antiquarian and poet. P'u-shu-t'ing shu hua pa is a record of the colophons he wrote on 25 paintings and 17 pieces of calligraphy.

The 25 paintings include such important extant works as the Admonitions scroll in the British Museum, the Portrait of the Scholar Fu-sheng in the Municipal Museum in Osaka, and Chao Meng-fu's Autumn Colours in 
Ch'iao and Hua Mountains in the Palace Museum in Taiwan. Consequently, this short text is interesting despite its lack of any information other than Chu's colophons.

54. Wu Sheng 吴升, Ta-kuan 1u 大㹥見铰・Prefaces dated 1712. 20 chiian. (Ferguson, 3, 2). ISSCHC facsimile reprint of manuscript copy in the National Central Library (1970).

Wu Sheng's exact dates are not known; he probably died in 1712 or shortly after. According to the preface by Sung Lo 宋箨 (1634-1713) written when he was 79 sui in 1712 , Wu Sheng brought the catalogue to him in that year asking for a preface. Another preface, written in the same year by Wang Shih-min's eighth son Wang Shan 王掞 (1645-1728), states that Wu Sheng so exhausted himself writing Ta-kuan lu that he became seriously ill. Wang's preface also records that wu sheng was on friendly terms with his father, and no doubt with others of his circle.

Wu Sheng made and kept notes on the paintings and calligraphy he saw, and Ta-kuan $1 \mathrm{u}$ is an important catalogue. Chuian 1-9 are devoted to calligraphy. Chiian 10 consists of a list of scholar-officials of the Yuian and Ming dynasties, each with a short biography. Chiian 11-20 are devoted to about 450 paintings ranging from the Six Dynasties to the Ming, a considerable number of which can be identified with important extant paintings. 
Each entry records the material, technique and dimensions of the painting; it describes its subject matter and style; it transcribes all the inscriptions and colophons; and there are usually critical comments by Wu Sheng. Biographical details of painters are given at the beginning of the entry for the first work by each artist; anecdotes on paintings are sometimes given. Thus, Ta-kuan $1 \mathrm{u}$ is more informative than most catalogues. There are, however, two omissions: it records hardly any seals, and it does not state in whose collection a painting was at the time Wu sheng saw it.

The first edition of Ta-kuan 1u, collated by Li Tsu-nien 李祖年 from three manuscript copies, was printed in 1920. These three copies contain a number of textual variations. For example, one of them is without the biographies now contained in chuian 10. These biographies seem something of an anomaly as they are only of scholar-officials of the Yiian and Ming. There are two possible explanations for this. One is that $\mathrm{Wu}$ Sheng intended to compile a more complete list but died before doing so. The other is that it was compiled by some other person and was somehow incorporated into some of the manuscript copies. The biographies are brief and add little to what we know of the well documented personalities, but they are useful for the less known figures.

55. Li o 厲鶚, Nan-Sung yiian hua 1u 南宋院畫録. 1721. 8 chiian, supplement 1 chiian. (Ferguson, 9, 2). MSTS, Vol. 17, IV/4; ISTP, Vol. 15, no. 128. 
Ii O (1692-1752) was a poet and scholar. Nan-Sung yian hua $1 u$ is a text on the Southern sung Painting Academy, its artists and their paintings. The compilation is completely made up of quotations from diverse sources, including official history, local histories, painting catalogues, texts on the theory of painting, miscellanies, and so on. The bibliography at the end lists 91 titles and they range from sung to early $\mathrm{Ch}^{\prime}$ ing in date.

Chiian 1 is an odd collection of 31 quotations on diverse aspects of the Academy. Chian 2-8 are devoted to 97 artists of the Academy, arranged in a chronological order. Under each artist are assembled quotations on him or particular paintings by him, many in the form of colophons.

Li 0 used his sources uncritically. Given the array of reference works, a much more inteliigible introductory chiian 1 could have been compiled. The merit of this text is that anyone working on any of these 97 Southern Sung Academy artists can use it as a short cut to the information in the 91 works cited in the bibliography.

56. Chou Erh-hsieh 周=鼠, I-chuieh pien 一角編. Preface dated 1728. 2 chïan. (Ferguson, 1, 1). SITS, tse 11. [Library of Congress].

Chou Erh-hsieh was a Hangchou collector active in the early 18th century. I-chieh pien records about 35 paintings and seven pieces of calligraphy in his collection. In his preface, Chou states that only those 
items in good condition were included. The pieces are arranged in the order in which they were acquired in the years 1712 to 1728 .

All the paintings are of the Ming dynasty. Each entry provides full information on the painting: dimensions, materials, description, sea1s, and transcription of colophons. Furthermore, there is information on the kind of silk used on the mounting and the material of the roller knobs.

Chou Erh-hsieh was obviously interested in mounting, for he was the author of a treatise on the subject entitled Shang-yen su-hsin Iu 賞延素心録. For a fuller discussion of Chou Erh-hsiieh, see R.H. van Gulik, Chinese Pictorial Art as Viewed by the Connoisseur (Rome, 1958), p. 315ff.

57. An Ch'i 安岐, Mo-yuian hui-kuan 墨緣采制。 Preface dated 1742. 4 chïan, supplement 2 chüan. (Ferguson, 15, 4). ISTP, Vol. 17, no. 161.

An Ch'i (ca. 1683-after 1744), a wealthy salt merchant of Korean extraction resident in Tientsin, was a distinguished collector and connoisseur. Mo-yiian hui-kuan, which may be paraphrased as "A Record of the Calligraphy and Painting it was my Destiny to See", is an annotated catalogue of the calligraphy and paintings in his collection as well as some of those he saw belonging to others. His preface is dated 1742, but the very first entry in chüan 1 was added in 1744 when he obtained a choice piece of calligraphy. 
Chuian 1-2 are devoted to calligraphy, chiian 3-4 to paintings, which range from works attributed to Ku K'ai-chih to those by Tung Ch'i-ch'ang. An Ch'i does not include in his catalogue any paintings by Ch'ing artists, nor does he include any Ch'ing dynasty seals in his entries. One hundred and fifteen handscrolls, hanging scrolls and a small number of albums of single artists are arranged chronologically; these are followed by 14 albums each containing works by more than one artist. For each item, An Ch'i specifies the size, material, technique, and gives a brief description of the subject matter. He records and transcribes all but the least important of the seals and colophons. Critical comments are plentiful, and from these it is evident that $\mathrm{An} \mathrm{Ch}$ 'i was a connoisseur of remarkable insight and discernment. He would question traditional attributions, even those perpetuated by older and more famous connoisseurs, if he felt justified in doing so.

Appended to chian 2 is a supplement on calligraphy, and likewise appended to chüan 4 is a supplement on paintings which number 122 items. The entries in the supplement are brief, providing little more than a comment or two about seals and inscriptions, and occasionally there are errors. These have given rise to the suggestion that the supplement was written by An Ch'i's son, An Yianchung 安元忠, when some of the paintings had been sold after the collector's death and the decline of the family fortune; but this cannot be substantiated.

A number of An Ch'i's paintings and calligraphy were acquired by the Ch'ien-lung emperor in 1746 and are now in the National Palace Museum in Taiwan, and some items 
found their way into Western collections in the 20th century. Consequently, this important catalogue is of exceptional interest as it can be studied in conjunction with extant paintings.

For a fuller discussion of the catalogue, see Thomas Lawton, "The Mo-yian hui-kuan by An Ch'i", in National Palace Museum Quarterly, Special Issue No. 1: Symposium in Honor of Dr. Chiang Fu-tsung on his 70th Birthday (Taipei, 1969), pp. 13-35. For a translation of chiian 3-4 and supplement into English, see Thomas Lawton, An Eighteenth Century Chinese Catalogue of Calligraphy and Painting, unpublished Ph.D. dissertation presented to Harvard University, 1970.

58a. Chang Chao 張照 and others, Pi-tien chu-1in 秘共珠林. 1744. 24 chuian. (Ferguson, 10, 8). Facsimile reprint of an original manuscript copy (Palace Museum, Taipei, 1971). [Freer].

In January, 1744, the Ch'ien-lung emperor commissioned the compilation of a catalogue of the Buddhist and Taoist paintings and texts in the imperial collection. The catalogue was completed and presented to the throne in the summer of the same year. This marked the beginning of a series of catalogues of the Ch'ing imperial collection compiled during the reigns of the Ch'ienlung (1736-1795) and Chia-ch'ing (1796-1820) emperors.

In his directive to the board of editors, the Ch'ien-lung emperor decreed that the storage location 
of the paintings was to serve as the broad basis for the arrangement of the material to be catalogued. This principle, of dubious merit, was adhered to in all the subsequent catalogues, rendering them difficult to use without an index. (This defect is remedied by the 1971 reprint which has a comprehensive index prepared by the Palace Museum staff). Within the grouping of the halls or palaces in which the items were stored, the following order was observed: works by the Ch'ing emperors, works by noted calligraphers and painters, and printed texts and images. A distinction is made between those works which are considered to be of good quality and those considered to be of secondary quality, designated "shang-teng 上等" and "tz'u-teng 次等 "respectively. For the former, all pertinent information on materials, technique, measurements, signature, inscriptions, colophons and seals is recorded and transcribed. For the latter, the information is much less complete. Only signatures and the names of the writers of colophons are recorded.

58b. Wang Chieh 王术, and others, Pi-tien chu-lin hsi-pien 秘殿珠林䋶編. 1793. 8 chiian. (Ferguson, 10, 8). First printed edition, 1948. Facsimile reprint of an original manuscript copy (Palace Museum, Taipei, 1971). [Freer].

In 1791, forty-seven years after the completion of pi-tien chu-lin ( $\underline{q} \cdot \underline{v}$.$) , a sequel was commissioned$ by the Ch'ien-lung emperor and it was completed in 1793. Pi-tien chu-1in hsii-pien was compiled in conjunc- 
tion with Shih-ch'ü pao-chi hsï-pien $\left(\underline{q} \cdot \underline{v}_{\text {. }}\right)$ and in both the 1948 and 1971 editions, the two hsi-pien appear under one title. They are similar in organization and contents of individual entries, and their differences from their respective predecessors are also comparable. The remarks on Shih-ch'ii pao-chi hsï-pien apply equally to Pi-tien chu-lin hsï-pien.

58c. Hu Ching 胡敬, Pi-tien chu-lin san-pien 秘殿珠林三編. 1816. 4 chian. (Ferguson, 10, 8). Facsimile reprint of an original manuscript copy (Palace Museum, Taipei, 1969). [Freer].

The final sequel to Pi-tien chu-lin $(\underline{q} \cdot \underline{v} \cdot)$ was compiled by order of the Chia-ch'ing emperor in 1816 in conjunction with Shih-ch'ii pao-chi san-pien ( $\left.\underline{q}^{\circ} \underline{v}_{\bullet}\right)$, and they appear under one title in the 1969 edition. In every respect it is similar to Pi-tien chu-lin hsii-pien $(\underline{q} \cdot \underline{v}$.$) .$

59a. Chang Chao 張照 and others, Shih-ch'ii pao-chi 石渠筫笈・ 1745. (Ferguson, 5, 8). HFL facsimile reprint (1918) of the SkCS text; 44 chiian. [Freer]. Facsimile reprint of an original manuscript copy (Palace Museum, Taipei, 1971); $8+8+8+12$ chiian, 9 appendices. [Freer].

On April 23, 1744, the Ch'ien-lung emperor commissioned the compilation of a catalogue of the paint- 
ings and calligraphy in the imperial collection. Entitled Shih-ch'ii pao-chi, it was completed in 1745 and was formally presented to the throne in the tenth month, corresponding to October 25-November 22, 1745.

The paintings include those items (landscapes, birds and flowers, secular figure paintings, etc.) which were stored in various palaces and halls in Peking. They do not include the Taoist and Buddhist paintings (see pi-tien chu-1in and sequels, qq. $\underline{v}_{\cdot}$ ), nor the portraits of emperors and meritorious officials (see Nan-hsiin-tien tsun-ts'ang t'u-hsiang mu and $\underline{C h} \cdot a-k^{\prime} u$ ts'ang-chu t'u-hsiang mu, qq..$\left.\underline{v} \cdot\right)$, nor any of the paintings kept in the summer palaces at Mukden and Jehol (see Sheng-ching ku-kung shu hua $1 u$ and Nei-wu-pu ku-wu ch'en-lieh-so hua mu-1u, qq.v.).

As in Pi-tien chu-1in, the material is arranged. according to the hall or palace where the paintings and calligraphy were stored. These halls number fourteen, but it is evident that the bulk of the collection was stored in four of them, namely, Ch'ien-ch'ing-kung 乾清宫, Yang-hsin-tien 養心展, Chung-hua-kung 重苹宫, and Yü-shu-fang 御畫房. Within the context of each hall, the items are grouped into the following categories: (1) calligraphy in albums, paintings in albums, (3) calligraphy and paintings combined in albums, (4) calligraphy on handscrolis, (5) paintings on handscrolls, (6) calligraphy and paintings combined on handscrolls, (7) calligraphy on hanging scrolls, (8) paintings on hanging scrolls, and (9) calligraphy and paintings combined on hanging scrolls. Within each category works by the Ch'ing em- 
perors (Shun-chih, K'ang-hsi and Ch'ien-lung) are catalogued first, followed by works by calligraphers and painters in chronological sequence. The organization of the material according to storage location renders the catalogue difficult to use. The 1918 edition has neither table of contents nor index, and the only way to use it was through Ferguson. But the 1971 reprint has both a table of contents at the beginning of each chiian and a most comprehensive index which lists all the items under individual painters and calligraphers, as well as all the colophons under their writers.

Again, as in pi-tien chu-1in $\left(\underline{q} \cdot \underline{v}_{\cdot}\right)$, all the items in the catalogue are designated either "shangteng 上等" (superior category) or "tz'u-teng 次等" (secondary category). Entries for the latter are brief. Although these "secondary" items form but a small proportion of the total, they could have been more fully catalogued. The entries for the "superior" items contain full information on dimensions, materials, technique, signature, inscriptions, colophons and seals, written with consistency and meticulous care. The attributions are strictly traditional or according to what the Ch'ien-lung emperor had pronounced on them. occasionally the compilers would contribute a few comments at the end of an entry, but on the whole, they show little evidence of independent research. This is regrettable but perhaps understandable as the catalogue was commissioned by the emperor whose self-esteem as a connoisseur was enormous. 
It will be noticed that the 1918 and 1971 editions are not identical in arrangement. In the 1971 reprint, which is actually based on an earlier text than the 1918 reprint, the chiian are not numbered consecutively, or more precisely, they are numbered consecutively only within each of the four principal halls, while the relatively small number of items in the ten other halls are relegated to the appendices. In some of the entries in the appendices, there are a number of colophons by Ch'ien-lung which post-date 1745, the year of completion of Shih-ch'ii pao-chi. For example, the entry for the Tzu-ming version of the Fu-ch'un shan-chii t'u attributed to Huang Kung-wang includes colophons by the emperor dated in correspondence to 1746, 1747 and 1748 (p. 1244). This anomaly indicates that either the appendices were added after 1745, or the entries were brought up-to-date after the emperor had written more colophons. It would appear that at the time when Shih-ch'iu pao-chi was incorporated into the Ssu-k'u ch'uian-shu in the $1770^{\prime} \mathrm{s}$ and $1780^{\prime} \mathrm{s}$, certain changes were made to the original text. These are: changes in the order necessitated by changes in the physical location of certain groups of paintings and calligraphy; the appendices were turned into regular chiian; and all the chijan were given consecutive numbers, with designation of hall locations.

59b. Wang Chieh 王术 and others, Shih-ch'i pao-chi

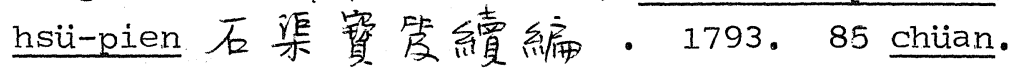
(Ferguson, 5, 8). Facsimile reprint of an original manuscript copy (1948). [Freer]. Facsimile reprint of an original manuscript copy (Palace Museum, Taipei, 1971). [Freer]. 
In 1791, forty-six years after the completion of Shih-ch'ii pao-chi $\left(\underline{q} \cdot \underline{v}_{.}\right)$, the Ch'ien-lung emperor commissioned a board of ten editors to compile a sequel to that catalogue. Shih-ch'ui pao-chi hsi-pien was completed in 1793 and bears a preface of that date by the emperor. Basically it is a catalogue of the large numbers of calligraphy and paintings amassed by the emperor through gifts from officials and occasionally through purchase in the intervening forty-six years. But it also records a large number of works by $\mathrm{Ch}$ 'ienlung himself.

In organization the hsi-pien follows its predecessor, but it has an index in the beginning to works listed under their artists who are arranged in a chrological order. Ironically the index does not serve its purpose well because the references are to names of halls and palaces, of which there are many more than in Shih-ch'ï pao-chi, rather than to pagination. However, with the 1971 reprint, which has a comprehensive index of paintings and colophons with references to normal pagination, the problem has disappeared.

In content, hsï-pien is a better catalogue than its predecessor. The qualitative classification into "superior" and "secondary" categories is abolished, so that all the paintings are catalogued equally fully. Compilers' comments are more frequent than in Shih-ch'i pao-chi, and these contain much useful information on the identity of the lesser known collectors and connoisseurs who had affixed seals or written colophons on the paintings. If the editors are not as independent in their final evaluation of the artistic worth of the 
paintings as we would wish, it is because of the nature of the catalogue being commissioned by the emperor. In all but this one respect, Shih-ch'ii pao-chi hsii-pien is an exemplary catalogue.

Several innovations in the lay-out, such as the use of paragraphs, of indenting, and of smal1 characters for the editors' comments, make the catalogue much easier to use and better in appearance than its predecessor.

59c. Hu Ching 胡荻 and others, Shih-ch'ui pao-chi san-pien 石渠资筫三編・1816. (Ferguson, 5, 8). Facsimile reprint of an original manuscript copy (Palace Museum, Taipei, 1969). $4618 \mathrm{pp}$. [Freer].

In 1816, an inventory was taken of the imperial collection of painting and calligraphy, and it was found that some 2,000 more items had been added to the collection since the completion of Shih-ch'üpao-chi hsï-pien and pi-tien chu-lin hsï-pien (qq.V.) in 1793. The Chia-ch'ing emperor therefore commissioned the compilation of a further sequel to the catalogues.

In organization, method and content of individual entries, and in 1ay-out, Shih-ch'ü pao-chi san-pien closely resembles hsi-pien and most of the remarks on hsi-pien apply. One difference is that, unlike in hsiipien, the component parts of the catalogue are not numbered consecutively, so that it is not possible to cite the number of chiian, and the number of pages in the 
1969 reprint is given instead.

Shih-ch'ii pao-chi san-pien includes a section (pp. 4514-4618) on the portraits of past emperors, empresses, sages and meritorious officials stored in the Nan-hsin-tien. It is actually a combined list of the items recorded in Nan-hsin-tien tsun-ts'ang t'uhsiang mu and in Ch'a-k'u ts'ang-chu t'u-hsiang mu (qq. $\underline{\mathrm{v}}$.$) . The number of hanging scrolls, albums and$ handscrolls totals 121, which agrees exactly with the figures in the two earlier texts. However, the entries are much fuller than in the earlier texts. Apart from giving the dimensions and noting the materials used, each entry describes the costume of the sitter and provides lengthy biographical information. This section of san-pien is sometimes treated as an independent text under the title of Nan-hsuin-tien t'u-hsiang k'ao 南薰殿圆像考, and has been printed as such in a collection of Hu Ching's writings.

The importance of all three parts of Shih-ch'i pao-chi can hardly be exaggerated. They are important because the paintings were what they were, and because a large proportion have survived and are available for study in the Palace Museum in Taiwan, and a small number are in public and private collections elsewhere.

60. Nan-hsïn-tien tsun-ts'ang t'u-hsiang mu 南薰共 尊藏圆像目・1749.1 chüan. (Ferguson, 9, 5). SLTS. [Library of Congress]. 
This is an inventory, taken in 1749 by order of the Ch'ien-lung emperor, of the portraits of past emperors and empresses stored in the Nan-hsin-tien. The 79 hanging scrolls, 15 albums and three handscrolls are arranged in a chronological order of the subjects of the portraits, beginning with the rulers of the legendary dynasties through to the Ming. For each portrait, the dimensions are given and the materials noted.

The bulk of these portraits (67 hanging scrolls, ten albums and two handscrol1s) are preserved in the Palace Museum in Taiwan, and are recorded in Ku-kung shu hua 1u $\left(\underline{q} . \underline{v}_{.}\right)$, chiian 7 .

\section{Ch'a-k'u ts'ang-chu t'u-hsiang mu 菒汼藏具宁 停像目. 1749. 1 chiian. (Ferguson, 10, 9). SITS. [Library of Congress].}

This is an inventory, taken in 1749 by order of the Ch'ien-lung emperor, of the portraits of meritorious officials stored in the $\mathrm{Ch}^{\prime} \mathrm{a}-\mathrm{k}^{\prime} \mathrm{u}$. (The $\mathrm{Ch}^{\prime} \mathrm{a}-\mathrm{k}^{\prime} u$, or Tea Storehouse, was one of the six imperial storehouses administered by the Kuang-ch'u-ssu 腐信者司, Department of Supplies. It would seem that even the Ch'ien-lung emperor had storage problems.)

The 21 hanging scrolls and three albums are arranged in a chronological order of the subjects of the portraits, from Han to T'ang. For each portrait, the dimensions are given and the materials noted. 
62. Ch'en Chuan 陳推, Yü-chi-shan-fang hua wai-1u 玉几山房畫外録. 2 chuian. (Ferguson, 5, 4). MSTS, Vol. 4, I/8; ISTP, Vo1. 14, no. 125.

Ch'en Chuan was a poet and painter of landscape and flowers who lived approximately from 1670 to 1740 . Yü-chi-shan-fang hua wai-lu is a compilation of quotations on paintings chosen at random from the writings of 49 persons of the late Ming and early Ch'ing. The value of this text is minimal.

63. Tu Mu 都穆 [ sic., Anon.], T'ieh-wang shan-hu 金戴網珊瑚. 20 chuian. (Ferguson, 20,2). ISSCHC facsimile reprint of the manuscript copy in the National Central Library (1970).

The traditional attribution of this text to $\mathrm{Tu}$ $\mathrm{Mu}$ (1458-1525) is incorrect. The edition cited above has no preface, but some editions of T'ieh-wang shan-hu have a preface by Shen Te-ch'ien 沈德潜(1673-1769) dated 1758. In it, Shen attributes the work to $\mathrm{Tu} \mathrm{Mu}$ and states that he was asked to contribute a preface by Tu's seventh generation descendant Tu Chao-pin 都肇斌 who was instrumental in arranging to have the text printed for the first time. T'ieh-wang shanhu is probably a fabrication of the Ch'ieh-lung period.

The text is a hopeless hotch-potch made up of various corrupt texts on painting, calligraphy, bronzes, musical instruments, and so on, arranged in a most haphazard way. About half the chiian are devoted to painting. These are: chiian 4 to the beginning of chiian 8; 
chiian 12 to the first half of chiian 15; and chiian 1820. One of the texts on painting included is Tu Mu's Yij-i pien $\left(\underline{q} \cdot \underline{v}_{.}\right)$, and this may account for the persistent misattribution of the entire $T^{\prime}$ ieh-wang shan-hu to him. It occupies chian 5.

Other texts on painting incorporated are Ho Liangchün's "Shu hua ming-hsin 1u" ( $\underline{q} . \underline{v}$.$) in chiian 6:15a-22b;$ T'ang Hou's Hua chien $(\underline{q} . \underline{v})$ ) in chiian 12; T'ang Yiun-mou's Yiin-yen kuo-yen hsiu-1u $\left(\underline{q} . \underline{V}_{.}\right)$in chiian 14; and Chou Mi's Yin-yen kuo-yen $1 \mathrm{u}(\underline{q} \cdot \underline{v}$.$) in chuian 18-20. Some of the$ other chian on painting in T'ieh-wang shan-hu are of uncertain authorship.

That $T^{\prime}$ ieh-wang shan-hu is a compilation postdating $\mathrm{Tu}$ Mu's death in 1525 is a matter of absolute certainty. Lo Liang-chiin's "Shu hua ming-hsin 1u" has a preface dated 1556 and a postscript dated 1567. There are other references in the text to dates after 1525 (chiian 7:17b; chiian 8:4a).

It is evident that T'ieh-wang shan-hu does not deserve any serious attention.

64. Chang Keng 張庚, T'u-hua ching-i shih 圆畫 精意諳. 1 chüan. (Ferguson, 14, 2). MSTS, Vol. 11, III/2; ISTP, Vol. 14, no. 121.

Chang Keng (1685-1760) was the compiler of several books on Ch'ing painters. T'u-hua ching-i shih records 85 paintings which he had seen. The text was not printed until the late 19th century; it has a preface dated 1888. 
The 85 paintings range from the T'ang to Ming, and a number of them are important paintings. The text is not a catalogue in the strict sense of the word. The items are not arranged in chronological order, nor do the entries contain al1 the pertinent information such as measurements and a complete transcription of al1 the colophons and sea1s. What the work lacks in completeness it makes up for in its stylistic analysis of some of the paintings. The discussions of stylistic matters are sound, and they are all the more valuable for being so rare in Chinese texts.

65. Ch'en Ch'uo 侓焯, Hsiang-kuan-chai yü-shang

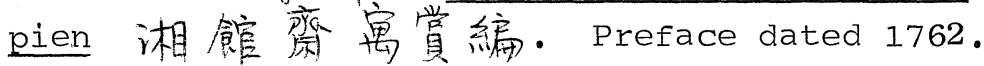
6 chiian. (Ferguson, 12, 2). MSTS, Vol. 19, IV/8; ISTP, Vol. 19, no. 169.

Ch'en Ch'uo was a scholar and connoisseur active in the reign of Ch'ien-lung in the 18th century. Hsiang-kuan-chai yij-shang pien is a catalogue of the calligraphy and paintings he had seen. Chiian 1-4 are devoted to calligraphy, and chian 5-6 to 73 paintings ranging from the Sung to the Ming, and arranged chronological1y. None of the paintings is of any particular importance. Each entry gives materials and dimensions and records inscriptions, colophons and sea1s. Ch'en usually records the dates and the circumstances under which he saw the paintings. His comments are in the nature of appreciation rather than research and critical judgement. 
66. Iu Shih-hua 陸時化, Wu-Yuieh so-chien shu hua

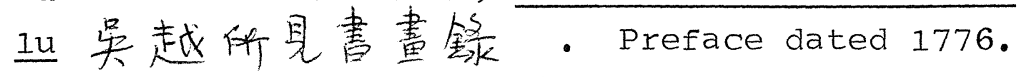
6 chiian. (Ferguson, 7, 2). ISSCHC facsimile reprint of the 1909 edition (1972).

Iu Shih-hua (1714-1779) was a connoisseur and Wu-Yieh so-chien shu hua $1 u$ is a catalogue of 628 paintings and calligraphy he saw in his native suchou and vicinity.

There is no attempt to arrange the material in any systematic way. Paintings and calligraphy are not separated, nor are the different formats of handscroll, hanging scroll and album. Each of the first five chüan records paintings and calligraphy of different dynasties and formats, but within each chian, the items are in a roughly chronological order. Chiian 6 is devoted to paintings of the Ch'ing dynasty, restricted to the so-called orthodox School (the Four Wangs, Wu Ii and Yïn Shou-p'ing).

The individual entries are thorough and written with care. Each entry records the precise measurements of painting and end-papers and gives a description of the painting. Inscriptions, colophons and seals are meticulously transcribed. Occasionally there are biographical details and critical comments.

67. Li Tiao-yuian 专言周え, Chu-chia ts'ang-hua pu 諸家藏畫簿. Preface 1778. 10 chuian. (Ferguson, 16, 2). HH. [Freer]. 
Li Tiao-yian (1734-1803) was a scholar and bibliophile. Chu-chia ts'ang-hua pu is a list of the titles of paintings in various collections in the past, copied verbatim from the first five-sixths of chiian 2 of Shihku-t'ang shu hua hui-k'ao $(\underline{q} \cdot \underline{v} \cdot)$ by Pien Yung-yü.

68. Juan Yüan 阮元, Shih-ch'uisui-pi 石渠随笋。 8 chiian. (Ferguson, 5, 7). Yangchou, n.d. [Freer].

Juan Yüan (1764-1849), the celebrated antiquarian and bibliophile, was one of the ten editors of Shih-ch'i pao-chi hsï-pien and Pi-tien chu-lin hsï-pien (qq.. .). While compiling these catalogues in the years 1791-93, he made notes on some of the paintings and calligraphy, and these notes were published for the first time in 1842 under the title Shih-ch'i sui-pi.

The discussions of various paintings and calligraphy follow no fixed form, but vary in length according to the intrinsic interest of each. They testify to the keenness of Juan Yuian's mind and the independence of his approach to the problems of connoisseurship. These qualities were all the more remarkable as he was only in his twenties when the notes were compiled. Informal in its arrangement and full of lively observations, this text is an admirable companion and the perfect counterfoil to the official Shih-ch'ï pao-chi hsii-pien. 
69. Shih-pai-chai chu-jen十百夜主人, Shih-pai-

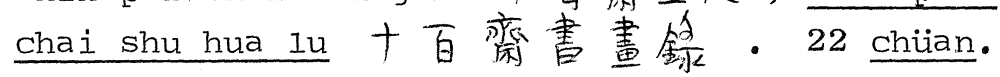
(Ferguson, 2, 1). Undated manuscript copy. [Stanford University Art Library].

The identity of the compiler remains a mystery. The short preface, unsigned and undated, states that the master of Shih-pai-chai had seen countless paintings and calligraphy, and had a collection of considerable size. It further states that Shih-pai-chai shu hua Iu was compiled over a period of twenty years.

In the text, no distinction is made between the items owned by the compiler and those belonging to others, if indeed it included things in his collection. More than a thousand paintings and calligraphy are recorded, the earliest items bearing a most improbable Han attribution. A fair number bear sung and Yian attributions, and the most numerous are Ming. The latest pieces are by painters active in the latter half of the 18th century, and a very tentative date around 1800 is advanced for the text.

The paintings and calligraphy are not separated, nor are they arranged according to format. There is no overall chronological sequence but within each chuian the items are in a more or less chronological order. This suggests that the whole catalogue may indeed have been compiled over 20 years, with the individual chian organized and written up after a certain interval of time.

Each entry records dimensions and materials; it records the artist's signature and inscriptions as well as colophons by and seals of important people. There 
are no critical comments or research of any sort. As far as can be judged from the text, the paintings are of indifferent quality. In the Stanford text, there is a single character at the top of each entry grading the item as either "excellent", "good", "ordinary", or "suspicious".

Shih-pai-chai shu hua lu appears to have never been printed. Ferguson used a manuscript copy, and the text here cited is also in manuscript form.

70. Wang Wen-chih 王文诒, K'uai-yü-t'ang t'i-pa 快雨堂题跋。 8 chuian. (Ferguson, 7, 4)。 n.d. [Harvard-Yenching].

Wang Wen-chih (1730-1802) was a poet and calligrapher of the Ch'ien-lung period. K'uai-yii-t'ang t'i-pa, compiled by a pupil probably after Wang Wenchih's death, is a collection of his colophons on some of the calligraphy and paintings he saw. Chiian 1-6 are devoted to calligraphy and chiian 7 and 8 to fifty paintings, ranging from sung to $\mathrm{Ch}$ 'ing. The paintings are arranged chronologically regardless of format.

Being colophons, the entries do not include any physical data such as materials, measurements and seals. They contain interesting critical comments and are informative on the transmission of the paintings. Occasionally Wang Wen-chih would transcribe an earlier colophon.

It is regrettable that the colophons here collected represent only a portion of Wang Wen-chih's 
writings in this area. Among the omissions are his colophons on such important extant paintings as Li Shan's Wind and Snow in the Fir-pines and Ch'iu Ying's Landscape in the Style of Li T'ang. Presumably the pupil who compiled the text did not have access to al1 the pertinent material.

71. Ch'ing-fou-shan-jen 青浮山人, Tung Hua-t'ing shu hua Iu 董萃庭書畫錄・ 1 chiian. (Ferguson, 13, 3). ISTP, Vo1. 25, no. 192 .

Ch'ing-fou-shan-jen has not been identified; he lived in the Ch'ing dynasty. Tung Hua-t'ing shu hua $\underline{\mathrm{Iu}}$ is a catalogue of some of Tung Ch'i-ch'ang's works. They consist of: (1) handscrolls: 9 paintings and 16 calligraphy; (2) hanging scrolls: 21 paintings and 5 calligraphy; and (3) albums: 9 paintings and 21 calligraphy.

For each item, Ch'ing-fou-shan-jen gives the title, the materials, the dimensions and transcribes Tung Ch'ich'ang's inscriptions and seals. In some cases, there are colophons by and seals of other people, some of whom were contemporaries of Tung $\mathrm{Ch}$ 'i-ch'ang, others were later collectors and connoisseurs. The latest colophon appears to be one by Wang Wen-chih 王文治 (1730-1802) dated 1800, which indicates that the text is a 19th century compilation. There is no preface to inform the reader whether the paintings and calligraphy were actually seen by the compiler or were merely recorded in other texts. 
72. Hu Ching 胡敬, Hsi-Ch'ing cha chi 西清茖言。 1816. 4 chüian. (Ferguson, 6, 8). ISSCHC facsimile reprint of the 1816 edition (1970).

Hsi-Ch'ing cha chi consists of notes on various paintings and calligraphy Hu Ching examined and catalogued when preparing Shih-ch'ii pao-chi san-pien ( $\underline{\text { q }} \cdot \underline{v} \cdot)$, the final sequel to the catalogue of the Ch'ing imperial collection. It is comparable to Juan Yüan's Shih-ch'ii sui-pi $(\underline{q} \cdot \underline{v}$.$) .$

All the entries are dated, and they are arranged according to the date on which Hu Ching saw the items. The choices were probably made on the basis of quality, as there are no more than one or two items for each day. The entries give fairly detailed descriptions of the paintings, record some colophons and usually end with a paragraph of comments consisting of the results of Hu Ching's own research. This text is a useful addition to san-pien.

73. Hu Ching 胡敬, Kuo-ch'ao yüan hua 1u 國朝院 畫钫. 1816. 2 chuian. (Ferguson, 11, 1). ISSCHC facsimile reprint of the 1816 edition (1970).

Hu Ching was the chief editor of Shih-ch'ii paochi san-pien (q.$\underline{v}$.$) . Kuo-ch'ao yüian hua 1u deals$ with 53 court painters of the Ch'ing dynasty up to the early 19th century. For each artist, there is a very brief biography running no more than one line, followed by a list of his paintings recorded in Shin- 
ch' $\ddot{i}$ pao-chi as well as in its hsü-pien and san-pien $(\underline{q q} \cdot \underline{v} \cdot)$. In many cases, the paintings are listed by title only. In others, Hu Ching has added annotations noting any colophons added by the Ch'ien-lung emperor, sometimes transcribing the verses.

Although this text is nothing more than excerpts from the three parts of Shih-ch'ü pao-chi, its one merit is that it isolates the Ch'ing court painters from all the other painters recorcied in those catalogues, presenting them as a group with their status as court painters in common. Anyone interested in pursuing them further can go to the fuller sources (Shih-ch'ii pao-chi and Ku-kung shu hua 1u, qq.. .) as well as to Pi-tien chu-lin and its supplements $(\underline{q q} \cdot \underline{v}$.$) where some of their works are recorded.$

74. Wu Hsiu 吴修, Ch'ing-hsia-kuan Iun-hua chuiehchui 青霞管諞畫絶句. Preface dated 1824 . 1 chiian. (Ferguson, 8, 6). MSTS, Vo1. 8, II/6; ISTP, Vol. 16, no. 139.

Wu Hsiu (1764-1827) was a scholar and painter. Ch'ing-hsia-kuan lun-hua chüeh-chui is an assemblage of 100 poems about 100 paintings Wu Hsiu had seen, ranging from the T'ang to the Ch'ing dynasty. Some of these were in his own collection, and others belonged to friends.

The poems are of the chiieh-chii type, consisting of four lines with seven characters to each line. They are not at all informative. However, following each poem is a paragraph in prose whose style is informal 
and chatty, containing such data as dimensions, materials, subject matter, colophons, and references to earlier catalogues, although not as fully or consistently as one would wish. In addition, Wu Hsiu would relate the circumstances under which he acquired a painting, or, if a painting belonged to someone else, he would give the name of the current owner. In a few instances, he includes interesting information on recent mountings which the paintings had undergone. Some of the paintings recorded in this text are extant.

75. P'an Shih-huang 潘世璜, Hsü-ching-chai yün-yen

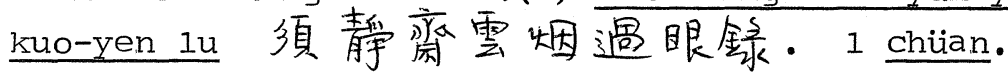
(Ferguson, 12, 13). MSTS, Vo1. 7, II/4; ISTP, vol. 18, no. 162 .

$P^{\prime}$ an Shih-huang (1764-1829) belonged to a family of distinguished scholars. Hsii-ching-chai yuin-yen kuoyen $1 \mathrm{u}$ is a record of the calligraphy and paintings shown to him by relatives and friends between the years 1804 and 1829. The preface by his grandson P'an Tsunch'i 墦嘾衩 is dated 1855. The text was printed in 1910 with a postscript bearing that date.

The paintings are few in number and insignificant. The entries are arranged in the order in which $\mathrm{P}^{\prime}$ an Shih-huang saw them. They do not record measurements and materials; inscriptions and colophons are noted but not transcribed. Occasionally there are comments by the compiler. Appended to certain entries are terse statements by Ku Wen-pin 雇页林多 (1811-1889) ( $\underline{\mathrm{q}} \cdot \underline{\mathrm{V}}_{\bullet}$ ) and Fei Nien-tz'u 䩀念䒺(1855-1905). The value of 
this text is minimal.

76. Chang Ta-yung 偯大鏞, Tzu-i-yieh-chai shu

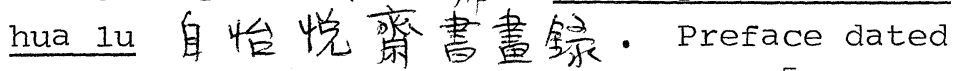
1832. 30 chiian. (Ferguson, 6, 6). [Stanford University Art Library].

Tzu-i-yieh-chai shu hua $1 u$ is a catalogue of more than 500 paintings and calligraphy, the majority of which were in the collection of Chang Ta-yung. The earliest painting bears a Sung attribution, but most of the paintings are of Ch'ing date and a number are by some of Chang's virtually unknown contemporaries.

Paintings and calligraphy are not separated. The items are divided according to format, and within this grouping there is a chronological sequence. Each entry gives the dimensions and notes the materials; it records seals and colophons. There are no critical comments, or references to earlier catalogues.

Chang Ta-yung seems utterly devoid of flexibility in his approach to his catalogue. One piece of calligraphy attributed to Chu Yin-ming is the text of Ko-ku yao-lun 格古要㝃, the wel1-known early Ming treatise on antiquities by Ts'ao Chao 曹昭. In the entry for this item, the entire text of this celebrated and easily accessible book is transcribed. The result is a most tedious catalogue, particularly as the paintings are of such mediocre quality. 
77. T'ao Liang 陶媣, Hung-tou-shu-kuan shu hua chi

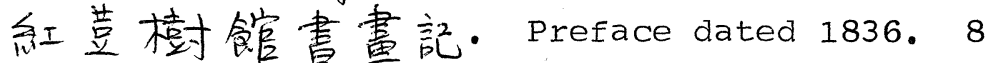
chuian. (Ferguson, 9, 10). ISSCHC facsimile reprint of the 1882 edition (1972).

T'ao Liang (1772-1857) was a collector and Hanlin scholar. Hung-tou-shu-kuan shu hua chi is a catalogue of the more than 300 paintings and calligraphy in his collection; chian 8 records some paintings and calligraphy which he saw in other people's collections. His preface bears the date of 1836, but the work was not printed until 1882 .

The paintings and calligraphy are not put into separate categories, but are arranged together in a chronological sequence. Handscrolls and hanging scrolls are treated together, but albums are grouped together in chian 6 and 7. Eighteen scrolls and three albums bear pre-Ming attributions, and the remaining paintings are of Ming and Ch'ing date. Each entry gives dimensions, materials and a description of the painting; inscriptions, colophons and seals are fully transcribed. T'ao Liang's remarks provide substantial evidence of his research and sound judgement. In chüan 8, information on current ownership is usually given.

Hung-tou-shu-kuan shu hua chi is typical of the kind of solid catalogue which had become standard by the 19th century.

78. Hu Chi-t'ang 胡皘堂, Pi-hsiao-hsian shu hua Iu

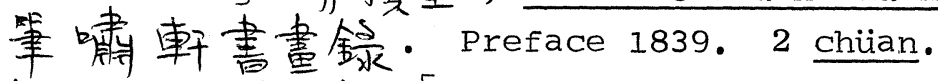

(Ferguson, 12, 7). [Stanford University Art Library]. 
According to the preface by the compiler's friend Wang Tse $\mathrm{I}$ 粟, dated 1839, the paintings and cal1igraphy recorded in Pi-hsiao-hsian shu hua $1 \mathrm{u}$ were in Hu Chi-t'ang's own collection.

Chiian 1 records about 320 paintings and calligraphy in the form of hanging scrolls; chuian 2 records a large number of albums, followed by a small number of handscrolls. With a few exceptions, the works are of Ming and Ch'ing date. The entries are brief, recording materials, artists' signatures, inscriptions and seals, and occasionally other people's Colophons. Measurements are not given. There are no critical comments and no references to records in earlier texts.

As far as can be judged, the paintings are of indifferent quality, and the catalogue is insignificant.

79. Sun Hsing-yen 㗪星行, P'ing-chin-kuan chients'ang shu hua chi 平津飧鑑藏意畫記・ 1841. 1 chiian. (Ferguson, 5, 3). GMS, no. 147. [Freer microfilm].

Sun Hsing-yen (1753-1818) was a scholar, bibliophile and calligrapher. P'ing-chin-kuan chien-ts'ang shu hua chi, printed in 1841, was edited by Ch'en Tsung-i 陳宗橎 who discovered the manuscript when he was going through Sun's papers in connection with another publication project. Ch'en's preface is dated 1840 .

The catalogue records 60 paintings and some calligraphy, the majority of which were in Sun Hsing-yen's 
collection while a few belonged to friends. In the case of the latter, Sun would note the current owner. The paintings range from the T'ang to the Ming, the very first entry being the Portraits of Thirteen Emperors attributed to Yen Li-pen now in the Museum of Fine Arts, Boston.

The entries do not give dimensions, information on materials, or description of the paintings. For such a late catalogue, these omissions are unusual. The entries do record seals and transcribe inscriptions and colophons. Sun Hsing-yen did a considerable amount of research on the paintings, and his critical comments are interesting. At the end of the catalogue is a list of 52 titles of paintings with no catalogue information.

80. Wu Jung-kuang 吴策光, Hsin-ch'ou hsiao-hsia chi 辛丑銷夏記・1841。 5 chüan. (Ferguson, 7, 5). ISSCHC facsimile reprint of the 1905 edition (1970).

Wu Jung-kuang (1773-1843) was a scholar, collector and official who served in various capacities until the spring of 1841 when he was forced by the emperor to retire. In the summer of that, the hsin-ch'ou, year, he compiled the catalogue Hsin-ch'ou hsiao-hsia chi. It records 144 paintings and calligraphy, some of which were in his own collection and others he had seen.

The 86 pieces of calligraphy and 58 paintings are not put into separate categories; they are arranged chronologically regardless of their format. The earliest paintings have attributions to the Five Dynasties and the 
latest are late Ming in date. Each entry gives information on materials, measurements and subject matter, and transcribes inscriptions, colophons and sea1s. In his preface, Wu Jung-kuang states that he takes as his models Sun Ch'eng-tse's Keng-tzu hsiao-hsia chi and Kao Shih-ch'i's Chiang-ts'un hsiao-hsia 1u (qq.v.). Actual1y, his catalogue provides much fuller information on the paintings than the former, and surpasses the latter in research and connoisseurship. The substance of Wu Jung-kuang's comments on the paintings is always interesting. This is an excellent catalogue.

81. Liang Chang-chii 梁章銀, T'ui-an so-ts'ang chinshih shu hua pa 退盘所藏金石書畫跤・Preface dated 1845. 20 chiian. (Ferguson, 10, 10). ISSCHC facsimile reprint of the 1845 edition (1972).

Liang Chang-chii (1775-1849) was a scholar, collector and official whose last appointment before retirement was the governorship of Kiangsu province. T'ui-an so-ts'ang chin-shih shu hua pa is a catalogue of the calligraphy, paintings, bronzes and other objects in his collection.

Chiian 11-20 are devoted to paintings, arranged chronologically regardless of format. The earliest have T'ang attributions and the latest are early Ch'ing in date. Most entries give a brief biographical sketch of the artist, and are informative on the history of the painting's transmission. On the other hand, they seldom give such information as dimensions or materials, and only those colophons by eminent collectors are recorded. 
82. Chang T'ing-chi 涱廷渻, Ch'ing-i-ko t'i-pa 清侍我备题跋: 1 chuian. (Ferguson, 11, 5)。 [Harvard-Yenching].

Chang T'ing-chi (1768-1848) was an antiquarian and collector. Ch'ing-i-ko t'i-pa is a collection of his study notes on diverse antiquities, including bronze inscriptions, old coins, tiles, stelae and calligraphy. Only five of the entries are concerned with paintings, none of them of significance. The text was edited and printed posthumously in 1892 .

83. Chiang Kuang-hsi 蒋光照, Pieh-hsia-chai shu

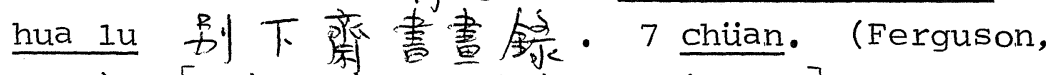
7, 1). [University of Chicago Library].

Chiang Kuang-hsii (1813-1860) was a noted bibliophile and a collector of painting and calligraphy. Pieh-hsia-chai shu hua $1 \mathrm{u}$ is a catalogue of his collection, compiled in 1850. In 1859, the Taiping rebels burnt and pillaged his home town of Chia-shih 原石 in Chekiang province, and most of his collection and his immense library were destroyed. After his death, the surviving manuscript was prepared for publication by his friend Kuan T'ing-fen 管庭芬（1797-1880), who contributed a preface dated 1865 .

The paintings and calligraphy are arranged in no perceivable order, neither chronological nor according to format. The entries contain full information on dimensions, materials, seals, inscriptions and colophons. The collection appears to have been of mediocre quality, and since the paintings no longer exist, the 
catalogue has little worth except as a record of Chiang Kuang-hsi's collection.

84. Han T'ai-hua 暲泰萧, Yü-yü-t'ang shu hua chi 玉雨堂書畫言己. Preface dated 1851.4 chiian. (Ferguson, 5, 5). MSTS, vo1. 7, II/3; ISTP, Vol. 18, no. 163.

Han T'ai-hua's dates do not appear to be recorded, but he must have been active in the second quarter of the 19th century. The preface by Shen T'ao 讴湔is dated 1851. Yü-yï-t'ang shu hua chi is the catalogue of a selection of the better pieces from his collection; they number 52 paintings and 28 pieces of calligraphy. The paintings range from sung to the early Ch'ing.

Dimensions of the paintings are given very infrequently, and as a rule, only the artist's own inscriptions and seals are recorded. On the other hand, Han T'ai-hua is meticulous in giving information on material, subject matter, style and general impressions of the paintings. His statements on his own reaction to the paintings are interesting and suggest that he was a keen connoisseur. Despite the omissions, the catalogue is good, and some of the paintings may be extant.

85. K'ung Kuang-t'ao 孔廣烸, Yiieh-hsieh-1ou shu hua 1u 㤃計雪樓書黄録. 1861. 5 chiian. (Ferguson, 17, 1). ISSCHC facsimile reprint of the 1889 edition (1972). 
K'ung Kuang-t'ao, active during the middle decades of the 19th century, was a 70th-generation descendant of Confucius. Yuieh-hsuieh-lou shu hua lu is a catalogue of the paintings and calligraphy in his collection. His father K'ung Ch'ih-t'ing 孔瀻庭 was a keen collector, and both $K^{\prime}$ ung Kuang-t'ao and his brother $K^{\prime}$ 'ung Kuang-yung 孔廣鏞 (born 1816) became collectors and connoisseurs in their own right.

The 139 items are arranged chronologically. The majority are paintings, ranging from T'ang to Ming. In each entry, $K$ 'ung Kuang-t'ao records the material, the dimensions, and the technique of execution. He transcribes all the inscriptions and colophons, including his own, as well as all the seals. His research and critical comments are embodied in his colophons. The entries are of uniform excellence, and some of the paintings are extant.

86. Li Tso-hsien 李佐賢, Shu hua chien-ying 書畫 鑑影 - 1871. 24 chiian. (Ferguson, 10, 5). ISSCHC facsimile reprint of the 1871 edition (1970).

Li Tso-hsien (chin-shih 1835) was a collector and connoisseur active in the mid-19th century. Shu hua chien-ying is a catalogue of more than 500 paintings and calligraphy which he had seen. The paintings range from T'ang to Ch'ing. They are not separated from the calligraphy, but are organized according to their format of handscrolls, albums and hanging scrolls; within each category, there is a chronological sequence. 
Each entry gives full information on dimensions, material and subject matter, and records and transcribes all seals, inscriptions and colophons. In these respects, Shu hua chien-ying is typical of the many excellent catalogues of the 19th century. There are, however, no critical comments by Li Tso-hsien. Some of the paintings recorded are extant.

87. Fang Chün-i 方溶賢, Meng-yuian shu hua 1u 夢園書畫䤼. Preface dated 1875. 25 chiian. (Ferguson, 14, 3). 1877 edition. [Freer].

Fang Chün-i (1815-1889) was a collector and official who served, among other posts, as salt controller of Kuangtung province, and many of his early acquisitions were from well-known collections in that province. Meng-yian shu hua $1 \mathrm{u}$ is a catalogue of about 400 paintings and calligraphy in his collection.

Paintings and calligraphy are not treated separately but are arranged together in chronological sequence regardless of format. The paintings range from the Six Dynasties to the Ch'ing. Each entry gives dimensions, materials and a detailed description of the painting. It records seals and transcribes colophons, including those by Fang Chün-i himself in which his comments on the paintings are to be found. This is a good catalogue and some of the paintings may be extant. 
88. Tu Jui-1ien 杜袮聫, Ku-fen-ko shu hua chi

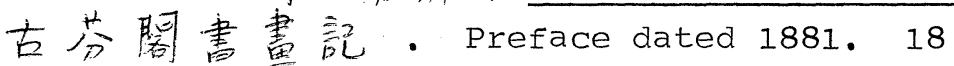
chuian. (Ferguson, 5, 1). [Library of Congress]. Ku-fen-ko shu hua chi is a catalogue of the paintings and calligraphy in the collection of $\mathrm{Tu}$ Jui-lien, who served as inspector of Kueichou province. The collection was large, and many of the works are of improbable antiquity. In painting, the array of Six Dynasties and T'ang works would have been most impressive if they were genuine. This is an indication of the low level of Tu Jui-lien's connoisseurship and calls for caution in accepting even the works of more recent date recorded in the catalogue.

Chuian 9-18 are devoted to painting. Each entry gives measurements and materials, describes the subject matter, and records seals. It also contains a paragraph of comments and encomium.

Much of the text recurs in Yen-fu pien by Yang En-shou ( $\underline{q} \cdot \underline{v}$.$) , who also contributed a preface to$ Ku-fen-ko shu hua chi, and it is possible that he did some of the writing for $\mathrm{Tu}$ Jui-lien.

89. Ko Chin-1ang 葛金烺, Ai-jih-yin-1ou shu hua Iu

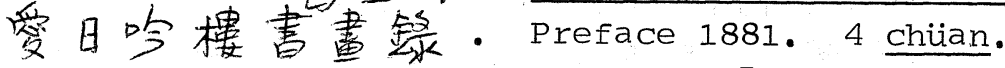
(Ferguson, 13, 1). 1910 edition. [Freer]. Ko Ssut'ung 暮嗣娜, pu-1u 補錔, 1912, 1 chuian;

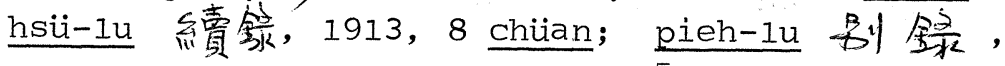
1913, 4 chian. 1913 edition. [Library of Congress]. 
Ko Chin-lang (died 1890) was a collector active in the late 19th century. Ai-jih-yin-lou shu hua 1u is a catalogue of about 110 selected paintings and calligraphy from his collection. They are not put into separate categories, but are arranged in chronological sequence regardless of format. The paintings range from sung to Ch'ing.

Each entry gives dimensions and information on materials, and transcribes seals, inscriptions and colophons. In addition, there is a paragraph describing the painting, recording its condition and occasional1y the price paid for it. It also notes where the painting had been previously recorded, and incorporates some research on the painter and/or some of the persona1ities whose calligraphy or seals appear on the painting. This is a good and full catalogue, typical of the 19th century.

Ko Chin-lang's son, Ko Ssu-t'ung, subsequently added a supplement of 1 chiian, a sequel of 8 chiian, and an appendix of 4 chiian in which more paintings and calligraphy are recorded in the same manner. However, he appears to be less of a scholar and connoisseur than his father.

90. Ku Wen-pin 雇自文林, Kuo-yin-1ou shu hua chi

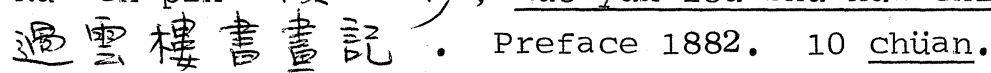
(Ferguson, 13,4). ISSCHC facsimile reprint of the 1883 edition (1970).

Ku Wen-pin (1811-1889) was a scholar, calligrapher and collector. Kuo-yin-1ou shu hua chi, named after his 
residence in Suchou which still stands today, is a catalogue of about 200 paintings and some calligraphy in his collection.

In his preface, Ku Wen-pin stated the rules which he set himself for the compilation of the catalogue. Some of them may strike the reader as eccentric. For example, Mi Fei was quoted as saying that the spirit of a painting is lost from silk after 800 years, and for that reason $\mathrm{Ku}$ Wen-pin decided to exclude all paintings on silk from his catalogue. Most of the other rules are eminent1y sound, and they testify to the high level of his connoisseurship. Ku scrupulously excluded all works from his catalogue which he considered spurious, even though they might have been accepted as genuine by earlier connoisseurs.

Chiian 5-10 are devoted to paintings, which range from T'ang to $\mathrm{Ch}$ 'ing. The catalogue is not very complete on basic data. The entries do describe the paintings but do not give measurements. Seals and colophons are not exhaustively recorded. On the other hand, the catalogue is excellent on background material on artists and paintings, and each entry is the result of thorough research.

Ku Wen-pin's sons and grandsons inherited not only his collection but also his passionate interest in painting and calligraphy, and some of them became quite notable artists. Despite the splitting of the collection, a portion of $\mathrm{Ku}$ Wen-pin's original collection has survived. Before his death in 1951, Ku Wen-pin's grandson Ku Kung-hsiung 雇自公厷住 expressed the wish to present his collection to the nation. By 1961, the entire 
collection totalling 393 items had been presented by his family to the People's Republic of China. (Lin Ch'iao-mu 林喬木, "Kuo-yün-lou ming-chung Chiangnan 適雲梙名重江南", in I-1in ts'ung-1u剩林 箃銥, second series, [Hong Kong, 1962])。

91. Yang En-shou 楊恩憘, Yen-fu pien 眼福編. Preface dated 1885. First series, 14 chiian; second series, 15 chüan; third series, 7 chuian. (Ferguson, 11, 6). 1885 edition. [Freer].

Yang En-shou was a close associate of Tu Jui-lien, whose collection of paintings and calligraphy is catalogued in $\mathrm{Ku}-\mathrm{fen-ko}$ shu hua chi $(\underline{\mathrm{q}} \cdot \underline{\mathrm{V}}$.$) .$

In his preface to Yen-fu pien, Yang En-shou relates that $\mathrm{Tu}$ used to ask him to write colophons on his paintings and calligraphy, and the 14 chuian in the first series record these colophons. This part of the text is worthless because of the dubious quality of Tu Juilien's collection and because each entry contains no more than the transcription of Yang En-shou's colophon on a particular painting or calligraphy.

The second series of Yen-fu pien is a catalogue of paintings and calligraphy from Tu Jui-lien's and several other collections, none of which was of any significance. Unlike the first series, however, the entries here are of some value because they contain full catalogue information on the paintings: measurements, materials, subject matter, seals, colophons, to whom the paintings belonged, and where they had been previously recorded. 
The third series consists of nothing but encomiums on paintings and calligraphy in Tu Jui-1ien's collection and is utterly worthless.

92. Lu Hsin-yiian 陸心漂, I-ku-t'ang t'i-pa 儀雇臬堂 题跤・1890. 16 chüan. I-ku-t'ang hsü-pa 儀雇堂䋶脯, 1892, 16 chiian. (Ferguson, $15,1)$. [Library of Congress].

Iu Hsin-yian (1834-1894) was an avid collector of books and antiquities. I-ku-t'ang t'i-pa is essentially a collection of his study notes on the books in his library, but there are recorded a small number of paintings and calligraphy.

A total of 19 paintings are recorded, seven in chüan 14 and 15 of I-ku-t'ang t'i-pa, and twelve in chiian 15 and 16 of I-ku-t'ang hsi-pa. The entries are lengthy and have information on materials, measurements, inscriptions, colophons and seals. The paintings are catalogued again in Lu Hsin-yüan's Jang-1i-kuan kuo-yen $\underline{1 u}(\underline{q} \cdot \underline{v}$.$) where they more properly belong.$

93. Lu Hsin-yian 陸心源, Jang-1i-kuan kuo-yen 1u

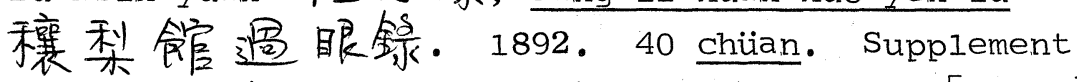
16 chiian. (Ferguson, 22, 1). 1892 edition. [Freer].

Iu Hsin-yian (1834-1894) was a scholar and an avid collector of books and antiquities. His antiquarian interests ranged from bronzes to paintings and calligraphy. Jang-1i-kuan kuo-yen lu is a catalogue of 482 paintings and calligraphy, most of which were in his 
family collection, and the rest belonged to friends.

The items are arranged chronologically regardless of format. The paintings range in date from the Six Dynasties to the Ch'ing, Ming dynasty works being the most numerous. Each entry records the measurements, the inscriptions, colophons and seals. It does not give any information on the subject matter or the technique. Lu Hsin-yian quotes from older catalogues but does not offer any critical comments of his own. In the cases of those items which did not belong to him, he would give the names of the owners.

The supplement, finished in the same year, catalogues 206 more paintings and calligraphy.

94. Li Yü-fen 李王菜, Ou-po-1o-shih shu hua kuo-

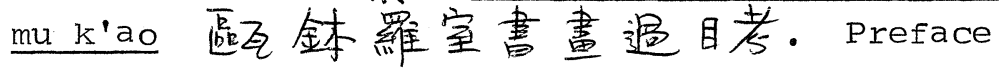
1894. 4 chian, supplement 1 chian. (Ferguson, 16, 1). MSTS, Vol. 25, V/9; ISSCHC facsimile reprint of the 1910 edition (1970).

Ii Yi-fen lived in the late Ch'ing dynasty but his exact dates are not known. Ou-po-1o-shih shu hua kuo-mu k'ao is a record of the paintings and calligraphy by 829 Ch'ing dynasty artists he had seen. The scope of the book is limited to the Ch'ing dynasty, beginning with the Four Wangs, Yuin Shou-p'ing and Wu $I i$ and ending with Li Yï-fen's contemporaries.

The material is arranged in the following way: nine princes in a section proceding chian 1; 746 painters and calligraphers in a roughly chronological sequence in 
chiian 1-4; 17 Buddhist priests, 5 Taoists and 52 women painters and calligraphers in the three chiian of the supplement. For each person, Li Yü-fen provides a brief biography, followed by an enumeration of his or her works he had seen; these are tersely described.

As a catalogue, the information is far from complete. The merit of this compilation lies in the large number of Ch'ing dynasty painters and calligraphers assembled.

95. Shao Sung-nien 召松年, Ku-yian ts'ui-1u 古緣 萃银 1904. 18 chiian. (Ferguson, 5, 2). 1904 edition. [Freer].

Shao Sung-nien lived in the late Ch'ing dynasty, but his exact dates are not known. Ku-yian ts'ui-1u is a catalogue of his large collection of paintings and calligraphy. A considerable number of pieces were

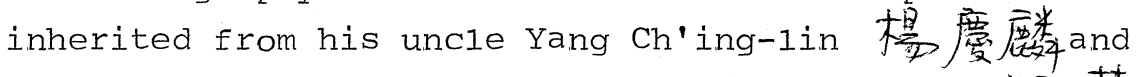
they are designated by the name "P'ing-lu-chai 并瓦樷 率", Yang's studio.

There is no table of contents. Paintings and calligraphy are not put into separate categories and are arranged in a chronological sequence, chiian 1 dealing with T'ang and Sung works, chüan 2 with Yüan, chuian 3-7 with Ming, chüan 7-16 with $\mathrm{Ch}^{\prime}$ ing, and chuian 17-18 with rubbings of calligraphy carved on stone. Each entry contains full information on materials, measurements and a detailed description of the painting. Inscriptions, colophons and seals are recorded. Shao 
Sung-nien does not have critical comments for every painting, but when they do occur, they are sharp and astute.

96. Ii Pao-hsiin 李葆恂, Wu-i-yu-i-chai lun-hua

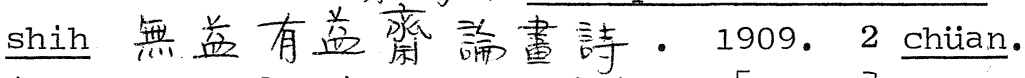
(Ferguson, 12, 3). 1909 edition. [Freer].

Li Pao-hsin (1859-1915) was a scholar and connoisseur. He was closely associated with the famous collector Tuan-fang 端 方 (1861-1911), advising him on his collection and helping to write some of his catalogues. Wu-i-yu-i-chai lun-hua shih is a record of 99 of the best paintings $\mathrm{Li}$ had seen, many of which were in Tuan-fang's collection and are so designated.

The paintings range from the Lo-shen t'u attributed to $\mathrm{Ku} \mathrm{K}^{\prime} \mathrm{ai}$-chih (now in the Freer Gallery) to a few of early $\mathrm{Ch}$ 'ing date, and the majority bear Sung and Yiuan attributions. Each entry consists of a verse in four lines with seven characters to each line, followed by a short paragraph in prose. The verse is in appreciation of the painting and is not informative. The notes forlowing give a description of the painting, and occasiona11y mention some colophons and seals, by no means exhaustively. Dimensions are omitted.

It is regrettable that the information is not as full as it could have been. (A much more complete catalogue, presumably of many of the same paintings, was compiled by Ii Pao-hsin in 1899, but the manuscript was destroyed during the Boxer uprising in 1900 and a much mutilated version survives in Hai-wang-ts'un so-chien 
shu hua $1 u, \underline{q} \cdot \underline{v}$.$) . Because Wu-i-yu-i-chai lun-hua$ shih is of such recent date and many of the paintings are still extant, the identification of entries with extant paintings is a matter of certainty.

97. Li Yü-fen 李玉菜, Wang Feng-ch'ang shu hua t'ipa 王奉常書畫是直咙, sometimes referred to as Yen-k'ot'i-pa 生要客题跋. 1909.2 chuian. (Ferguson, 4, 8). 1909 edition. [Freer].

Li Yü-fen $\left(\underline{q} \cdot \underline{v}_{\bullet}\right)$ lived in the late Ch'ing dynasty and he was much concerned with Ch'ing painting. Wang Feng-ch'ang shu hua t'i-pa is a collection of 175 inscriptions and colophons by the early Ch'ing master, Wang Shih-min 王時敏(1592-1680)。 Of these, 44 are inscriptions on his own paintings, and 131 are colophons on paintings and calligraphy by others. In his preface, Ii Yi-fen states that these were copied from his manuscript copy borrowed from a descendant of Sung Lo 宋㧛 (1634-1713).

The 175 items are arranged in an arbitrary order. Comparison of two particular inscriptions in the text (chian 2:10a and chian 2:13a-14a) with their extant originals (Wang Shih-min's inscription on his Six Album Leaves in the Styles of old Masters [Freer Gallery, acc. no. 62.29] and his colophon on Wang Hui's Dwelling in the Fu-ch'un Mountains after Hang Kung-wang [Freer Ga1lery, acc. no. 50.19]) reveals minor differences. The explanation for these is that Wang Shih-min probably kept copies of his inscriptions and colophons and went on polishing them as literary compositions. 
Not having any other information, this text does not help in any way in the identification of the paintings on which the inscriptions and colophons were written. But it does present a sizable body of Wang Shihmin's thoughts on paintings, provided one can wade through his rather ponderous literary style.

98. P'ang Yüan-chi 龐え㲔, Hsü-chai ming-hua $1 u$ 虚症名畫鉹. 1909. 16 chiian. Supplement in 4 chiian, 1924; addendum, 1925. (Ferguson, 12, 9). ISSCHC facsimile reprint of the original editions (1972).

P'ang Yian-chi (ca. 1865-1949) was a distinguished Shanghai collector. Hsii-chai ming-hua lu is a catalogue of his collection of paintings which was among the most important of his time.

The paintings are divided according to format and arranged chronologically. Chiian 1-6 are devoted to 124 handscrolls, chiian 7-10 to 345 hanging scrolls, and chiian 11-16 to 88 albums. The earliest paintings have T'ang attributions and the latest are Ch'ing in date. Each entry gives dimensions, materials and a very terse description of the painting. Inscriptions, colophons and seals are meticulously and exhaustively transcribed. In these respects, the catalogue is a model of clarity, consistency and thoroughness. But there are no critical comments by $\mathrm{P}^{\prime}$ ang Yüan-chi on the paintings, nor is there any information on where they were previously recorded.

Because the collection was formed relatively recently 
and stayed intact well into the 20th century, a considerable number of the paintings went into Western collections. These can be definitely identified with certain paintings recorded in Hsï-chai ming-hua 1u, thanks to the full documentation of their seals and colophons.

A supplement in 4 chiian entitled Hsii-chai ming-hua hsii-lu was compiled and printed in 1924. It is a catalogue of about 200 paintings acquired by P'ang Yuian-chi between the years 1909 and 1924. The arrangement differs from that of its predecessor in that all the paintings are arranged chronologically regardless of format. The contents of each entry remains much as in the 1909 catalogue, with the exception that the description of the painting is much more detailed. In his preface to hsii-lu, $P^{\prime}$ ang Yuian-chi states that in this respect he models himself on An Ch'i's Mo-yian hui-kuan ( q.

Bound with chiian 4 of hsï-lu is an addendum cataloguing six paintings acquired by P'ang Yiuan-chi in the spring of 1925 .

99. Ts'ai Yü-mou 蔡每荿, Chu-t'ang wen kao 竹堂 文稿. 1 chuian. (Ferguson, 6, 7).

This text has not been located. According to Ferguson, who used a manuscript copy, Ts'ai Yü-mou was a Ch'ing person.

100. Chin-liang 金梁, Sheng-ching ku-kung shu hua 1u 盛京故宫書畫録. Preface dated 1913. 7 tse. (Ferguson, 12, 6). ISTP, Vo1. 21, no. 172 . 
Chin-liang was a Manchu scholar who was active in the very last years of the Ch'ing dynasty and continued to be active as a literary editor well into the 1930's. Sheng-ching ku-kung shu hua $1 \mathrm{u}$ is a catalogue of about 450 paintings and calligraphy in the Ch'ing imperial collection stored in the Hsiang-feng-ko 翔闻閣 in the Summer Palace at Sheng-ching (Mukden). The catalogue was begun in 1908 and completed in 1913. The collection stored at the Hsiang-feng-ko was by no means the entire collection at Mukden; there were other halls in the Summer Palace whose holdings were not recorded.

The items are divided into seven categories: handscrolls, hanging scrolls, albums, sutras, panels, horizontal tablets and couplets. In each category, the Ch'ien-lung emperor's creations head the list, followed by other people's calligraphy and paintings arranged in a chronological sequence. Each entry gives the dimensions, notes the materials, and records the seals and colophons. occasionally Chin-liang contributes some critical comments.

The Hsiang-feng-ko holdings were later moved to the Ku-wu ch'en-lieh-so古物陳列所 in Peking (see Neiwu-pu ku-wu ch'en-lieh-so shu hua mu-lu, $\underline{\mathrm{q}} \cdot \underline{\mathrm{v}} \cdot$ ), and a smal1 number of the paintings are now in the National Centra1 Museum in Taiwan and recorded in Ku-kung shu hua $\underline{1 u}(\underline{q} \cdot \underline{v} \cdot)$.

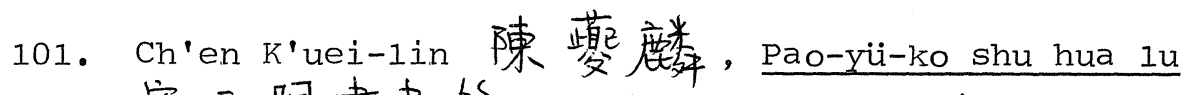

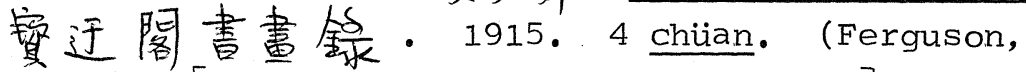
19, 1). [Stanford University Art Library]. 
Ch'en K'uei-lin (born ca. 1855) had a collection of several hundred paintings and calligraphy. Pao-yïko shu hua $1 u$ is a catalogue of a selection of the better examples in the collection: 50 handscrolls, 107 hanging scrolls and 63 albums. About 75\% is paintings, which are arranged with the calligraphy in a chronological order regardless of format. There are several paintings which bear Five Dynasties, Sung and Yiian attributions, but the vast majority are Ming and $\mathrm{Ch}$ 'ing.

The entries give information on materials and describe the paintings; dimensions are not given. Inscriptions and colophons are transcribed and seals are recorded. There are references to and lengthy quotations from earlier texts where some of the paintings are recorded. Ch'en K'uei-lin ends every entry with a paragraph of his critical comments and results of his research. This is a good catalogue and some of the paintings are extant.

102. Li Pao-hsiun 李葆恂, Hai-wang-ts'un so-chien shu hua lu ts'an-kao 海王村所見書畫錄威稿・ 1916. 1 chiian. (Ferguson, 10, 6). 1916 edition. [Freer].

The preface dated 1914 by Li Fang 李放, the son of Li Pao-hsuin (1859-1915) (q..$\left.\underline{v}_{\cdot}\right)$, states that Hai-wangts'un so-chien shu hua lu was completed by his father in 1899. It was in 10 chiian. The manuscript was destroyed during the Boxer uprising in the following year, and the present text was resurrected from an incomplete first 
draft; hence the "ts'an-kao" of the title.

Hai-wang-ts'un, sometimes referred to as Liu-1ich'ang 到㐫廠, was and still is the area of antique shops in Peking. In this much reduced text are recorded 14 paintings and two pieces of calligraphy which Li Paohsin saw there. A number of these are also recorded in Li Pao-hsiin's other compilation, Wu-i-yu-i-chai lun-hua $\underline{\operatorname{shih}}(\underline{\mathrm{q}} \cdot \underline{\mathrm{v}} \cdot)$.

In each entry, Li records measurements and materials; he notes the important seals and transcribes the colophons. At the end of the entry is a paragraph of his comments. This is an interesting catalogue, particularly as some of the paintings are extant, and the loss of the greater part of the original text is regrettable.

103. Ch'ung I 崇悉, Hsian-hsuieh-chai shu hua yiu-mu

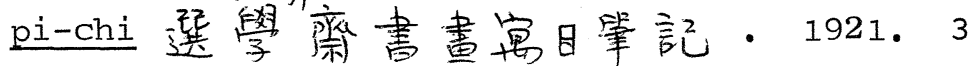
chiian. (Ferguson, 16, 3). 1921 edition in GMS, no. 92 . [Freer microfilm].

Ch'ung I was a modern collector and connoisseur active in the first decades of the 20th century. Hsianhsieh-chai shu hua yii-mu pi-chi is a catalogue of the paintings and calligraphy he saw between the years 1906 and 1921 .

The items catalogued are arranged according to format. Chiian 1 records 22 paintings in the form of handscrolls ranging from the sung to the Ch'ing dynasty, and 12 pieces of calligraphy. Chian 2 records 15 albums 
of paintings of late Ming and early Ch'ing date, and ten albums of calligraphy. Chiian 3 records 31 paintings in the form of hanging scrolls ranging from Sung to Ch'ing, and nine pieces of calligraphy.

The catalogue is exemplary. Materials, dimensions, description, inscriptions, colophons, seals, references to discussions in earlier catalogues, critical comments, and current owner - all the information that a reader could wish for is there. Apart from its excellence, the catalogue is valuable because some of the paintings are extant, as is to be expected of objects seen so recently.

A supplement in 3 chiian records 23 handscrolls, 15 albums and 31 hanging scrolls as well as some calligraphy. It was published in 1941 and the items were seen by Ch'ung $I$ in the previous 20 years. It is also in Gunnar Martins Samling av Kinesisk och Japansk Litteratur, no. 92.

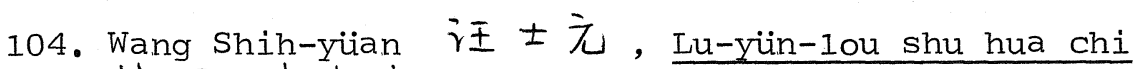
麓雲梙書畫記. 1922. 1 chuian. (Ferguson, 19, 6). [Stanford University Art Library].

Wang Shih-yian was a modern collector. Lu-yuin-lou shu hua chi is a catalogue of his collection of about 130 paintings, arranged in a chronological order with a few pieces of calligraphy. Several of the paintings bear sung and Yiuan attributions, but the majority of them are Ming and Ch'ing.

The entries are brief. They give approximate dimen- 
sions, information on materials and terse descriptions of the paintings. They note colophons but do not transcribe them. There are no critical comments. Among the paintings are some interesting items which must still be extant.

105. Ho Yui 何 大昱 and others, Nei-wu-pu ku-wu ch'en1ieh-so shu hua mu-1u 内部部古物陸列所

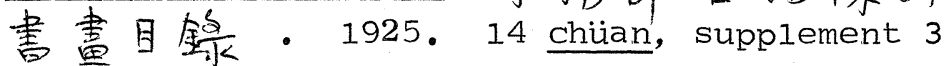
chiain, addendum 2 chiian. (Ferguson, 4, 1). 1925 edition. [Freer].

This is a catalogue of those paintings and calligraphy in the Ch'ing imperial collection which were stored in the two summer palaces at Feng-t'ien 奉天 (Mukden) and Jehol 热河 in Manchuria. In 1913, the second year after the establishment of the Republic, these items were moved to and exhibited at the Wen-huatien 文萧展 and the Wu-ying-tien 武茧展 in Peking, and they came under the custodianship of the Nei-wu-pu ku-wu ch'en-1ieh-so 内務部古物陳列所 (The Bureau of Exhibition of Antiquities, Ministry of the Interior).

Chian 1-4 are devoted to calligraphy. The paintings, catalogued in chian 5-14, are arranged chronologically under the following categories: albums (428), handscrolls (214), hanging scrolls (727), screen panels (323), horizontal hanging scrolls (50), diptyches (12), album of painting and calligraphy combined (1), handscrolls of painting and calligraphy combined (18), hanging scrolls of painting and calligraphy combined 
(4), screen panels of painting and calligraphy combined (41), portraits (15 albums), hanging scrolls of portraits (83), fan paintings and calligraphy combined (1301). The supplement deals with k'o-ssu and the addendum deals with sutras.

Each entry gives the measurements of the painting and a terse description of the subject matter; it also records the seals and colophons. There are no comments by the compilers. For the more important paintings, there are quotations of discussions in earlier catalogues.

A comparison with Sheng-ching ku-kung shu hua lu (q..$\underline{v})$ ) shows the entries in that catalogue to be more detailed than those in the present one. It also shows that a number of items recorded there are not in the present catalogue, indicating that they had been lost between the years 1913 and 1925 .

In the 1930's, the antiquities here catalogued were evacuated from Peking along with the antiquities of the Palace Museum by the personnel of that institution. After World War II, the Bureau of Exhibition of Antiquities was abolished, and the objects came under the custodianship of the Central Museum. In the winter of 1948, the most important pieces from the collection were moved to Taiwan along with the objects of the Palace Museum. The paintings and calligraphy in the two museums were catalogued in Ku-kung shu hua lu (q..$\underline{v}$.$) , and those$ in the Central Museum are designated "Chung po 中博". Pieces so designated number 231 paintings and 59 pieces of calligraphy in both the Cheng-mu and Chien-mu sections. These figures are drastically smaller than those in 
Nei-wu-pu ku-wu ch'en-1ieh-so shu hua mu-1u, thus indicating that the bulk of that collection was left in Nanking and is probably still there.

106. Kuo Pao-ch'ang 郭葆昌, Chih-chai shu hua Iu 解変書畵録! 1926. 1 chüan. (Ferguson, 19, 5). ISSCHC facsimile reprint of the 1926 edition (1970).

Kuo Pao-ch'ang is best known in the West as the supervisor of the manufacture of the official Hunghsien 洪密 ceramic ware at Ching-te Chen 景德鎮 during the administration of Yuan Shih-k'ai 袁世峈 (1913-16), and as the author of the introduction to the catalogue of the International Exhibition of Chinese Art held in London in 1934-35. He was equally knowledgeable on painting, and served as a special consultant to the Palace Museum in Peiping on his two specialities from 1928 to 1931.

Chih-chai shu hua $1 u$ is a catalogue of 47 paintings and 19 pieces of calligraphy in his collection, arranged together in chronological sequence. Each entry gives the dimensions and a brief description of the painting. It records the seals, and notes the colophons but does not transcribe them. Kuo does not offer any critical comments, but occasionally he quotes from earlier catalogues where the paintings are recorded and discussed. Kuo Pao-ch'ang was a discriminating collector, and some of the paintings are extant and in Western collections. 
107. Kuan Mien-chuin 關量鈞, San-ch'iu-ko shu hua 1u 三秋閣書畫録。1928. 2 chiian. (Ferguson, 3, 1). 1928 edition. [University of Chicago Library].

Kuan Mien-chïn was a modern collector. Sanch'iu-ko shu hua $1 u$ is a catalogue of 135 paintings and 50 pieces of calligraphy selected from his collection.

The paintings and calligraphy are arranged together in a chronological sequence. Each entry gives the dimensions of the painting and records the seals and colophons. There is no description of the painting except in the case of album leaves. Occasionally, Kuan Mien-chün contributes a few comments on the people who had written colophons and/or affixed seals to the paintings. Otherwise, there are no critical comments. At the end of the catalogue is a list of the couplets and fan paintings and calligraphy in the collection.

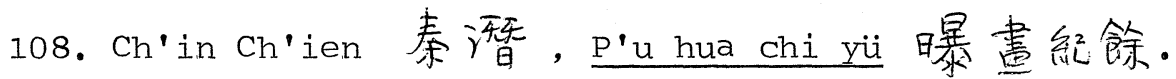
1929. 12 chiian. (Ferguson, 19, 4). 1929 edition. [Freer].

P'u hua chi yii is a catalogue of 339 paintings in the collection of the compiler's grandfather $\mathrm{Ch}$ 'in Ping-wen 秦炳文 (1803-1873) as well as 399 paintings by him.

Chiian 1, 3, 5, 7, 9 and 11 are devoted to handscrolls, albums, hanging scrolls, horizontal hanging 
scrolls, fan paintings and miscellaneous respectively. The vast majority of these are of Ming and $\mathrm{Ch}$ 'ing date. Chian 2, 4, 6, 8, 10 and 12 are devoted to paintings in corresponding format by $\mathrm{Ch}^{\prime}$ in $\mathrm{Ping}-\mathrm{wen}$. The entries record seals, inscriptions and colophons. Some of the measurements given are not exact. Comments by the compiler are few and far between. 
S.1. Chu Ching-hsian 朱景玄, T'ang-ch'ao ming-hua 1u 唐朝名畫睩・ 1 chuian. MSTS, Vol. 8, II/6; ISTP, Vo1. 8, no. 59 .

Chu Ching-hsian was active in the second quarter of the ninth century, but his exact dates are not known. T'ang-ch'ao ming-hua 1 u deals with 97 artists of the T'ang dynasty, and on internal evidence, Soper suggests that the work be assigned to the early $840^{\prime} \mathrm{s}$.

With the exception of three imperial princes and three painters put into the $i-p$ 'in (untrammelled) category, the painters are graded qualitatively into three divisions of "inspired", "excellent" and "competent", and within each of these, into three subdivisions of top, middle and bottom.

The work consists of a preface, a table of contents in which the name of each artist is supplemented with a list of his special themes, and the text where each of the 97 artists has an entry to himself in which his biography is given, anecdotes relating to him recounted, and some of his paintings discussed. Most relevant to our purpose is that in these discussions, specific titles are often mentioned, and some of the paintings are tersely described.

For a translation of this text into English, see Alexander C. Soper, "T'ang Ch'ao Ming Hua Lu", in Artibus Asiae, vo1. 21 (1958), pp. 204-230.

S.2. Chang Yen-yuian 張衰遠, Li-tai ming-hua chi 磨代名畫記・ 847 A.D. 10 chiian. ISTP, 
vol. 8, no. 58. Punctuated edition: in Chungkuo mei-shu lun-chu ts'ung-k'an 中國美術 論著丵刊 (Peking, 1963). [Freer]. Punctuated and annotated edition (Shanghai, 1964).

Chang Yen-yiian's exact dates are not known. Li-tai ming-hua chi was completed in 847 A.D. and he was still active in $874 \mathrm{~A}$. D.

The book can be divided into two parts. The first part, chuian 1-3, consists of discussions of various topics of painting: (1) the origins of painting; (2) the vicissitudes of great collections of painting; (3) a list of 370 painters from the earliest times to the T'ang dynasty; (4) Hsieh Ho's "Six Canons"; (5) landscapes, rocks and trees;

(6) the transmission of the art of the painting in the Six Dynasties period; (7) the brush method of Ku K'ai-chih, Lu T'an-wei, Chang Seng-yu and Wu Taotzu; (8) styles of painting, supplies, and the making of copies and tracings; (9) prices and quality; (10) connoisseurship, collecting and appreciation; (11) some examples of colophons; (12) some examples of seals; (13) mounting, backing, borders and rollers; (14) frescoes in Buddhist and Taoist temples in Ch'ang-an and Lo-yang; appended to this section is a list of the frescoes which survived the destruction of Buddhist temples in 845 A.D.; and (15) a list of 97 treasured paintings through the ages.

For our purpose, (14) and (15) are the most interesting sections from this part of the book as they contain specific titles of paintings. 
Part two of the book, chuian 4-10, deals with the 370 painters in section (3) above, ranging from the period of the legendary emperors to the T'ang dynasty. As in Chu Ching-hsian's T'ang-Ch'ao minghua $1 u\left(\underline{q} \cdot \underline{v}_{.}\right)$, each artist has an entry to himself, with brief biographical details, anecdotes about him, and discussions of his paintings. In these discussions, beginning with the Chin $\frac{\overline{4}}{1}$ dynasty, many specific titles are mentioned, usually of paintings which Chang Yen-yiian had actua $11 y$ seen. This part of the book is important for our purpose, for it is an early record of the titles of some of the paintings by Six Dynasties and T'ang artists.

For an introduction to Li-tai ming-hua chi and a translation of chiian 1-3 into English, see William R.B. Acker, Some T'ang and Pre-T'ang Texts on Chinese Painting (Leiden, 1954), pp. XLVII-L and 59-382.

S.3. Huang Hsiu-fu 黄休德, I-chou ming-hua 1u 道州名鲁㖉, sometimes referred to as Ch'eng-tu ming-hua 1u 成都名畫鉱. Preface dated 1006. 3 chian. WSSHY, chiian 9. [Freer].

Huang Hsiu-fu, whose exact dates are not known, was a Northern Sung scholar and connoisseur who was active in the late 10th-early 11th century. I-chou ming-hua 1 u deals with 58 artists from the mid-8th century to the mid-10th century who were active in I-chou, the present-day Szechuan province. It has a preface by Huang Hsiu-fu's friend Li T'ien 李田父, dated 1006. 
During the first half of the 10th century, I-chou was under the state of Shu which, with its centre at $\mathrm{Ch}$ 'eng-tu, was one of the two relatively peaceful regions in China in the upheaval of the Five Dynasties period, and a number of artists from Ch'angan and elsewhere had taken refuge there. The other centre was Nanking, capital of the Nan T'ang. In both these places painting flourished. From what little we know about the Shu school, it seems to have been the more avant-garde of the two. One feature of the school was the development of ink painting of the socalled i-p'in (untrammelled) style.

Huang Hsiu-fu's approach resembles that of Chu Ching-hsian in T'ang-ch'ao ming-hua $1 \mathrm{u}(\underline{q} \cdot \underline{\mathrm{V}} \cdot)$ ) and the artists are graded into four categories. Where Huang differs from $\mathrm{Chu}$ is in (a) his definition of the "untrammelled" category which he places qualitatively above the three categories of "inspired", "excellent" and "competent", and in (b) not subdividing the "inspired" category into top, middle and bottom. Each of the 58 artists has an entry to himself, with very brief biographical information and fairly lengthy discussions of his paintings. Specific titles are sometimes mentioned, and in the cases of artists who painted frescoes, the names of the temples where their works were executed are given.

This text is valuable for its information on the artists of an important centre of painting in the Five Dynasties period and the 150 years previous to that. 
S.4. Liu Tao-ch'un 劉道醇, Wu-tai ming-hua pu-i 五伐名書補遗. Preface dated 1060 .

I chian. ISSCHC facsimile reprint of a Ming edition in the National Central Library (1972).

Liu Tao-ch'un's dates are not known, but he must have lived in the middle decades of the 11 th century. According to $\mathrm{Ch}$ 'en Hsiun-chih's 榎询旦 preface dated 1060, the work was compiled to supplement Hu Ch'iao's 胡山合 Liang-ch'ao ming-hua mu 䐑朝名畫目; hence the "pu-i" of the titie. $\mathrm{Hu}^{\prime} \mathrm{s}$ book, which is no longer extant, discussed 43 painters of the Liang dynasty, the first of the five royal houses of the Five Dynasties period, and Iiu Tao-ch'un in Wu-tai ming-hua pu-i discusses 21 painters and four sculptors active at Nanking in the remaining four decades of the Five Dynasties period, roughly from 923 to 960 A.D.

The artists are classified into groups according to their specialities: figure painting; landscape; animals, birds and flowers; architecture; and sculpture. Within each group, the painters are graded into the categories of "inspired", "excellent" and "competent". Each artist has an entry with brief biographical information, followed by a discussion of his work; specific titles are rarely mentioned. The inclusion of information on sculptors is a most unusual feature.

S.5. Ii Chih 李庴, Te-yui-chai hua-p'in 德㭷留 書员, sometimes abbreviated to Hua-p'in. 1 chüan. MSTS, Vol. 18, IV/5; ISTP, Vo1. 10, no. 69. 
Li Chih lived towards the end of the Northern Sung dynasty but his exact dates are not known. A close friend of Su Shih 蘇軾 (1036-1101), Li survived Su by some years. Te-yiu-chai hua-p'in is a desscriptive catalogue of part of the painting collection of his patron Chao Ling-chih 勃令畤, a scion of the sung imperial family. Chao served at Hsiang-yang 衰隄 in Hupei province in 1098 and left the bulk of his collection at the capital at K'ai-feng. Li Chih's catalogue deals with the paintings Chao took with him to Hsiang-yang.

The 25 works, by famous masters ranging from the late T'ang through to the 11th century, include examples of secular figure painting, Buddhist painting. mythological painting, landscape, birds and flowers, animals, and architectural painting. Each entry consists of a description and a discussion of the painting, and a few seals are mentioned. The catalogue is of unusual interest as it is rare to have actual descriptions of paintings in early extant texts.

For an introduction to Te-yü-chai hua-p'in and a translation into English, see Alexander C. Soper, "A Northern Sung Descriptive Catalogue of Paintings", in Journal of the American Oriental Society, Vol. 69 (1949), pp. 18-33.

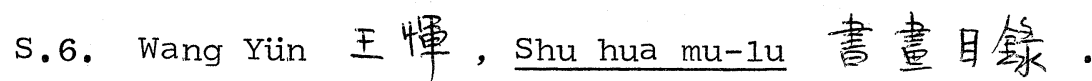
Preface dated 1276. 1 chïan. MSTS, Vol. 18, IV/6; ISTP, Vol. 17, no. 154. 
Wang Yün (1227-1304) was a scholar and a highranking official in the early years of the Yiian dynasty. In his preface to Shu hua mu-1u, dated 1276, he recounts how he came to see the 147 pieces of calligraphy and 81 paintings in the Yian imperial collection here recorded.

With a few exceptions, the paintings are recorded by title only, which is most regrettable. (One of the exceptions is the Portraits of Fourteen Emperors attributed to Yen Li-pen; the entry has enough information for the painting to be identified with reasonable certainty as the Portraits of Thirteen Emperors now in the Museum of Fine Arts, Boston.) The brevity of the entries notwithstanding, Shu hua mu-1u is of great interest, firstly because of its early date, and secondIy because of the intrinsic interest in the fact that it is a record of the Yian imperial collection. It should dispel to a certain extent the supposition that the Yiian represented a dark age in the history of imperial collections. It is generally thought that the Northern Sung collection was lost at the sack of Kai-feng, that the replacement so painstakingly built up by the Southern Sung emperors met a similar fate at the end of the dynasty, and that there was no imperial collection to speak of until the Ming.

A comparison of the titles in Shu hua mu-lu with those in Sung Chung-hsing-kuan-ko ch'u-ts'ang t'u-hua chi $(\underline{q} \cdot \underline{v}$.$) suggests that nineteen of the 81$ paintings recorded in the former were in the Southern Sung imperial collection. These constituted a link, however tenuous, between the two collections. 
S.7. Yuieh-sheng so-ts'ang shu hua pieh-1u 4 总生所藏

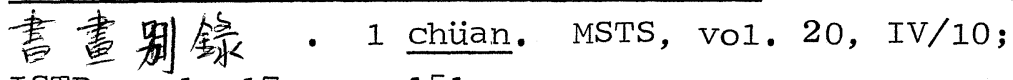
ISTP, VO1. 17, no. 151.

Yieh-sheng so-ts'ang shu hua pieh-1u is a list of some of the paintings in the collection of Chia Ssu-tao 賈似道 (died 1275), the infamous prime minister in the reign of Sung Li-tsung (reigned 12251264), whose favourite consort was Chia Ssu-tao's sister. Because of his position and power, Chia was able to amass an enormous collection, and some of his paintings are said to have been given to him from the imperial collection.

This 1ist, consisting of 58 paintings and 42 pieces of calligraphy, is culled from Yiieh-sheng pieh-1u 悦生别钫. The items are listed by title only and there is no other information.

S.8. T'ang Hou 晹后, Hua chien 畫鑑. 1 chiian. MSTS, Vol. 11, III/2; ISTP, Vol. 11, no. 82. Edition punctuated and rendered into modern Chinese: in Chung-kuo hua-lun ts'ung-shu 中 國 畵㻆丵書 (Peking, 1962). [Freer].

T'ang Hou is labelled a Sung man in some Chinese texts, but although his exact dates are not known, it appears that his life span fell entirely within the Yian dynasty. By internal evidence Hua chien can be dated to the 1320 's.

The work is a survey of painting traced through the principal practitioners from the Three Kingdoms period to the sung and Chin 金. In the cases of some 
painters, there are general critical comments as well as descriptions and discussions of specific paintings, while in the cases of others, statements are very brief. The arrangement of the book is good.

S.9. Hsia Wen-yen 夏文㢁, T'u-hui pao chien 圆繒 帮金監・Preface dated 1365. 5 chuian. ISTP, vol. 11, no. 83.

Hsia Wen-yen was a 14th century collector and his preface to $\mathrm{T}^{\prime} \mathrm{u}$-hui pao chien is dated 1365.

Chiian 1 is devoted to discussions of the theory of painting and miscellaneous topics. The rest of the book consists of entries on some 1,500 painters ranging from the Three Kingdoms period to the Yiian, including some non-Chinese painters. Each entry has brief biographical information on the artist and a discussion in general terms of his paintings. Specific titles are very seldom mentioned.

Because of the great number of biographies it had gathered together, the book was much quoted by Ming and especially $\mathrm{Ch}$ 'ing writers, and it became a standard reference. But a closer examination suggests that it does not deserve the high regard it enjoyed for so long. Its material is drawn from Li-tai ming-hua chi, T'u-hua chien-wen chih, Hsuian-ho hua p'u (qq.. .) and other early texts and catalogues. Hsia Wen-yen took sections from his various sources without paying attention to their individual arrangement and without devising an arrangement of his own. The result is that other than the 
broad grouping of artists by dynasty, there is virtually no organization.

As it appears in ISTP, T'u-hui pao chien has a sixth chiian compiled by Han Ang 暲昂 in 1519 consisting of biographies of 114 Ming artists. It a1so incorporates a supplement for some of the omissions in Hsia Wen-yen's text.

S.10. Wang Chih-teng 王㧝登, Wu-chuin tan-ch'ing chin 突郡丹青志. Preface dated 1563 . 1 chuian. MSTS, Vol. 6, II/2; ISTP, Vol. 12 , no. 95.

Wang Chih-teng (1535-1612) was a native of Suchou and a noted connoisseur. In Wu-chuin tan-ch'ing chih he discusses 25 suchou painters ranging from the 14th century to his own time, and puts them into seven categories.

Any reader whose hopes have been raised by Sirén's grandiose translated title, The Chronicle of Suchou Painters, will be bitterly disappointed. The work is short, its scope ill-defined, the choice of painters for inclusion as well as the grading arbitrary. The discussions of different painters are too general; they are not informative on biographical matters, style, or specific paintings. This is the work by a young man written to while away the time when he was confined to bed by iliness. 
S.11. Wu Ch'i-chen 吴某真, Shu hua chi 妻畫記. 6 chiian. Facsimile reprint of the copy in SKCS (Shanghai, 1962). [Freer].

Wu Ch'i-chen was a connoisseur of painting and calligraphy, active in the decades spanning the end of Ming and the beginning of Ch'ing. He knew all the collectors in Suchou, Hangchou and Yangchou, and Shu hua chi is a record of the 1,256 paintings and specimens of calligraphy which he saw in private collections in those cities in the years between 1635 and 1677. It was completed probably in 1677 or shortly after, but was printed for the first time in 1962 .

The items are arranged not chronologically, but in the order in which they were seen by Wu in the fortytwo years. This is admittedly not the best arrangement from the point of view of the research worker. Each entry describes the condition of the painting, records the artist's signature and sea1s, if any, and notes but does not record colophons by previous connoisseurs. Occasiona11y, measurements are given. Many of the entries are terse, and at first glance the book may appear to be rather erratic and therefore not very useful. In fact, the shortcomings of terseness and inconsistency are to a certain extent compensated for by two excellent features. First, the concluding remarks in nearly every entry consist of such information as the current ownership of the piece, the date Wu saw it, and sometimes the vicissitudes undergone by a painting in the recent past. Thanks to this type of information, the transmission of certain paintings can be more fully reconstructed. (An example of this is the invaluable information furnished by Wu 
for the reconstruction of the most crucial part of the history of Huang Kung-wang's Fu-ch'un shan-chii t'u.) Second, and perhaps more important, is the remarkable critical faculty which enabled $\mathrm{Wu}$ to cut through the jungle of impedimenta in the form of signatures, inscriptions, colophons and seals, and to go straight to the painting itself, often resulting in a terse pronouncement: "Later than attribution". This lack of gullibility is most refreshing and the more impressive for being so rare among Chinese connoisseurs. The catalogue is not free from errors, but these are usually minor ones, the result of lapses of memory and of inadequate notes being taken at the time the paintings were seen.

Before 1962, Shu hua chi was little known because it was never printed and because it fell under the shadow of Ch'ien-lung's censorship. The text was incorporated into Ssu-k'u ch'iian-shu 四度全書, the "Complete Library in Four Branches of Literature" compiled from 1773 to 1785, a compilation of all available books with the exception of those considered to be seditious to the regime or to be intellectually or moral1y offensive. What gave offence in Shu hua chi was Wu Ch'i-chen's description of an erotic painting attributed to chou Fang entitled Ch'un-hsiao pi-hsi t'u 春宵秘虔兽・The book is listed in Ssu-k'u ch'uan-shu tsung-mu t'i-yao 四庫全萧總目提要, a review completed in 1781 of the 3,450 titles to be included in, as well as the 6,780 titles to be excluded from, ssu-k'u ch'uian-shu. It is still listed in Ssu-k'u ch'ian-shu chien-ming mu-1u 四庫全㫪简明目錄, a simple list compiled in 1782 
of the 3,450 titles copied into the library, or more specifically, in the version printed in Hangchou in 1784, but not in the official version printed in Canton in 1868. The conclusion to be drawn is that short1y after 1784, the "pornographic" content of Shu hua chi came to the notice of the emperor's censors and the title was suppressed from chien-ming mu-1u. Fortunately, the book has survived in Ssu-k'u Ch'ian-shu although the entry on Chou Fang's painting no longer exists. The 1962 edition is a facsimile reprint of the manuscript copy from one of the four original sets of Ssu-k'u ch'ian-shu now in the Palace Museum in Peking.

S.12. Ku Fu 雇页復, P'ing-sheng chuang-kuan 平生牞整目・ Preface dated 1692. 10 chian. First edition based on manuscript copy in the Chekiang Cultural Bureau (Shanghai, 1962). [Freer]. ISSCHC facsimile reprint of a manuscript copy (1970).

$\mathrm{Ku} \mathrm{Fu}$ was a connoisseur of painting and calligraphy active in Nanking and Suchou in the middle and late 17th century. His exact dates are not known, but his own preface is dated in correspondence to 1692. Also dated 1692 is the preface by Hsii Ch'ien-hsieh 徐乾舁 (1631-1694), a close friend of Ku Fu's brother $\mathrm{Ku}$ Wei-yiieh 雇面維岳. From certain statements in $\mathrm{P}^{\prime}$ ing-sheng chuang-kuan, it is deduced that $\mathrm{Ku} F u$ was friendly with Wang Shih-min, Wu Li and Wang Hui. A1so, from certain sentiments expressed towards Ch'ien Hsian, Chao Meng-fu and other Southern Sung-Yian 
artists, it is conjectured that $\mathrm{Ku} F u$ was a Ming patriot and remained so under the Ch'ing dynasty.

P'ing-sheng chuang-kuan is a catalogue of the paintings and calligraphy which $\mathrm{Ku}$ had seen. Chian 1-5 are devoted to calligraphy, and chiian 6-10 to paintings which range from the Six Dynasties to works by Tung Ch'i-ch'ang of the late Ming, arranged in a chronological order. The entries are fairly brief; each one as a rule gives a description of the painting and takes note of, but does not record, the colophons. Approximate measurements are sometimes given, not at a11 consistent1y. Ku Fu does not pay much attention to seals, nor does he always give references to records of paintings in earlier catalogues. There is usually a paragraph of comments on each of the major painters, and comments on individual paintings are astute. This is an interesting catalogue, and some of the paintings recorded are still extant.

Iike Wu Ch'i-chen's Shu hua chi ( $\left.\underline{q} \cdot \underline{v}_{\cdot}\right)$, p'ingsheng chuang-kuan was never printed until 1962 . It was even less known than shu hua chi because it was never collected into any ts'ung-shu and had survived in manuscript form.

S.13. Tse Lang 退朗, San-wan liu-ch'ien ch'ing hu-chung hua ch'uan 1u 三萬六千㴪湖中 垂船錄 - Preface 1795. 1 chiian. MSTS, vol. 5, I/10; ISTP, Vol. 15, no. 132.

Tse Lang was a painter and seal carver active in the late 18th century (chï-jen 1789). San-wan 
liu-ch'ien ch'ing hu-chung hua ch'uan $1 \mathrm{u}$ is a catalogue of about 60 paintings he saw between the years 1782 and 1786, when he maintained a boat on the T'ai Hu 太湖, which covers an area of 36,000 ch'ing; hence the title.

While a few of the paintings are pre-Ming, the majority are Ming and Ch'ing. Dimensions are often but not always given. Otherwise the entries give fairly full information on materials, inscriptions, colophons and seals.

S.14. Shih-ch'ii pao-chi san-pien mu-1u 石渠算策 三編目釷录. 3 tse. Facsimile reprint of a manuscript copy (1917). [Freer].

Shih-ch'ii pao-chi san-pien $(\underline{q} \cdot \underline{v} \cdot)$, the third part of the catalogue of the Ch'ing imperial collection of painting and calligraphy, was compiled in 1816 but was not available to the general public until as recently as 1969. In 1917, the antiquarian Lo Chen-yii 羅振玉 (1865-1940) brought out Shih-ch'ï pao-chi san-pien mu-lu, a list of the titles of the paintings and calligraphy catalogued in san-pien. It is not an index in the strict sense of the word, but an excerpt of the table of contents at the beginning of the text. In his postscript dated 1917, Lo Chen-yii states that the list was taken from a manuscript copy from a Japanese collection. The titles gave a tantalizing glimpse of the contents of san-pien.

For 50 years mu-lu served a purpose until it was superseded by the 1969 reprint of the san-pien in 
the Palace Museum in Taiwan, with its original table of contents plus a comprehensive index prepared by the Museum staff.

S.15. P'an Cheng-wei 潘正煒, T'ing-fan-1ou shu

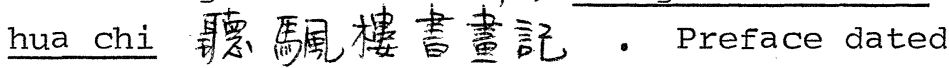
1843. 5 chiian. Supplement 2 chïan, 1849. MSTS, Vol. 19, IV/7; ISTP, Vo1. 20, nos. 170, 171.

P'an Cheng-wei (1791-1850), a wealthy Hong merchant, was one of the more prominent Cantonese collectors of the 19th century. In his preface, P'an states that the idea of compiling a catalogue of his collection was first suggested to him by his friend Wu Jungkuang, and it is not surprising that T'ing-fan-lou shu hua chi is so similar to Wu's catalogue, Hsin-ch'ou hsiao-hsia chi $(\underline{q} . \underline{v} \cdot)$, completed two years previously in 1841 .

The 255 paintings and calligraphy, ranging from T'ang to Ch'ing, are arranged together in chronological sequence regardless of format. There is a table of contents where the price paid for each item is noted. Each entry gives the dimensions and notes the use of either paper or silk, but does not note the use of colours. It transcribes the inscriptions, colophons and sea1s, but omits P'an Cheng-wei's own colophons. Consequently, we are left in the dark as to his reaction to the paintings, and are without the benefit of his research, if any.

The supplement, completed six years later, records 120 more works arranged and catalogued in the same way. 
S.16. Wu Chih-ying 吴之䒨, Hsiao-wan-liu-t'ang

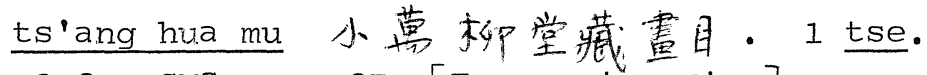
1918. GMS, no. 87. [Freer microfilm].

Wu Chih-ying (died 1933) and her husband Lien Ch'iian 廉家 (died 1931) were collectors of paintings. In 1918 they found themselves in debt to the amount of 20,000 dollars which they were unable to repay, and had to surrender thirty paintings in their collection to the creditor. Hsiao-wan-liu-t'ang ts'anghua $\mathrm{mu}$ is a tearful record of these thirty paintings by Wang Chien, Wang Hui, Wang Yiuan-ch'i, Yün Shou-p'ing and $\mathrm{Wu} \mathrm{Li}$; hence the alternate title, Hsiao-wan-liu-

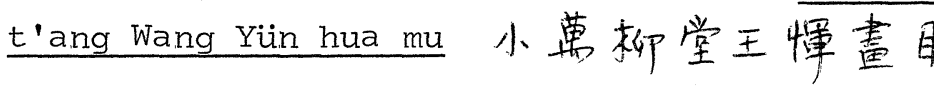

The work is strictly speaking not a catalogue in the sense that we have come to understand by that word by 1918. Each entry records only inscriptions and colophons, and contains no other information. However, it is of interest because some of the paintings are not recorded elsewhere. The book is a lithographic edition with the calligraphy by Wu Chih-ying who was a noted calligrapher.

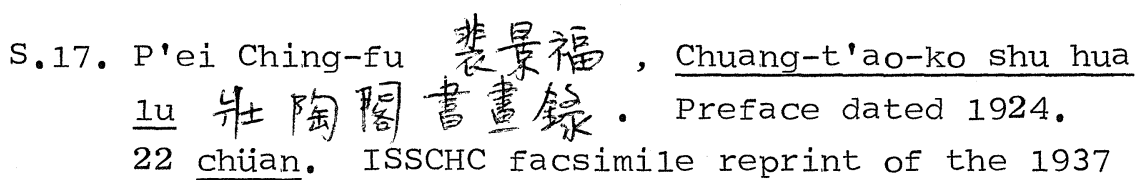
edition (1971).

P'ei Ching-fu (1854-1926) inherited a collection of paintings and calligraphy from his father which was formed in the third quarter of the 19th century, and he 
expanded it significantly. Chuang-t'ao-ko shu hua Iu, completed in 1923 and printed posthumously in 1937, is a catalogue of about 700 items in the collection.

The paintings and calligraphy, of roughly equal numbers, are not put into separate categories. They are arranged chronologically regardless of format. These occupy chijan 1-20; the last two chijan deal with those calligraphy items which are in the form of pei and tieh.

The earliest paintings have attributions to the Six Dynasties and the latest are Ch'ing. Each entry gives all the relevant information: materials, dimensions, description of painting, signature and inscription of the artist, seals and colophons, including P'ei's own colophons. There are detailed discussions of records of the paintings in earlier catalogues and how they differ from the documentation on his paintings. The assessment of his paintings after such investigations appears to be sound and fair.

This is an example of the kind of solid catalogue which we have come to expect from serious compilations of such recent date. A number of the items in this catalogue are extant.

S.18. National Palace Museum, Ku-kung $i-i$ shu-chi shu

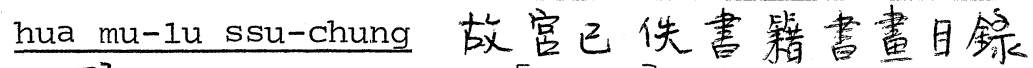
種・ Peking, 1934. [Freer]。

After the Revolution of 1911, the Hsian-t'ung emperor was not immediately deposed. On the contrary, 
he was accorded preferential treatment and allowed to stay in the Forbidden City where he continued to use his reign title and carry on as if the Revolution had not taken place. This anomaly lasted for thirteen years and it was not until November 5, 1924, that P'u-i 溥儀 and his family were forced to leave the palace and to surrender his imperial seals. The former imperial art collection naturally became national property, and a committee consisting of a chairman and fifteen members was set up to deal with all the problems arising from the transfer of ownership.

In 1925, the Committee came upon three lists of paintings, calligraphy and printed books which had been removed from the collection. The longest one, entitled "Items awarded to P'u-chieh 浦婪 [P'u-i's brother]", lists paintings, calligraphy and printed books numbering nearly 1,500 items given to $\mathrm{P}^{\prime} \mathrm{u}$-chieh in a period of five months in 1921. Many of these are choice items. The Committee published the lists in Ku-kung i-i shu-chi shu hua mu-1u san-chung 故宫已伕

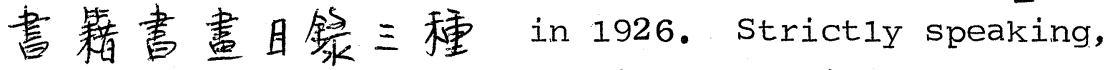
there were four, not three, 1ists, and in 1934, a slightly revised edition was published with the title altered to ssu-chung. Many of the items in the fourth list were actually borrowed and later returned.

A number of the paintings in these lists are now in American and Japanese collections.

S.19. Wan-yen Ching-hsien 究新景監, San-yü-t'ang

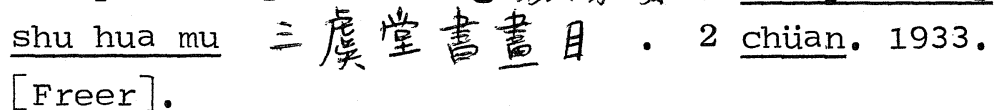


Wan-yen Ching-hsien was a Manchu connoisseur of the late Ch'ing dynasty and a close friend of the eminent collector Tuan-fang 端方 (1861-1911). He kept a record of the paintings and calligraphy in his own collection and those he had seen. After his death, the manuscript was secured by the artist $\mathrm{Su}$ Tsung-jen 辇宗仁, who edited it and arranged to have it printed in 1933 with a preface by him.

Seventy-five paintings, ranging from the Six Dynasties to the Ming, are recorded in chiian 2 . Most of the entries consist of the titles and very brief notations on their materials and whereabouts. There is no information on dimensions; inscriptions and colophons are not transcribed and very rarely mentioned. The incompleteness of the catalogue is regrettable. A good number of the paintings are extant and some are in Western collections.

S.20. Ch'en Jen-t'ao 淒仁悪, Chin-kuei ts'ang-hua

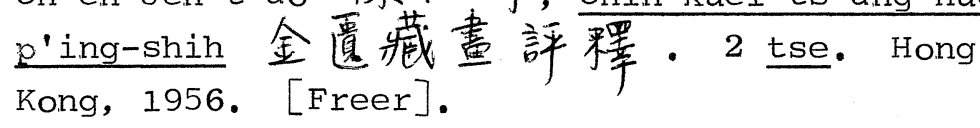

Ch'en Jen-t'ao (1906-1968) was one of the prominent collectors of the 20th century. Chin-kuei ts'ang-hua p'ing-shih is a catalogue of 117 paintings in his collection; a supplement records eight additional paintings. Ranging from the Five Dynasties period to the Ch'ing, the paintings appear to be of good quality, and although some of the oldest ones may not really be as old as their attributions, they are nonetheless fairly early copies preserving the styles and compositions of lost masterpieces. 
Each entry gives the materials and measurements of the painting, records the signature, inscriptions, and all the colophons and seals. The work would be a good and useful catalogue if it contained no more information than this. But as the "p'ing-shih" in the title implies, the compilation sets out to be more than a mere catalogue. In addition to the factual information on the painting, Ch'en Jen-t'ao provides the following on each item: (1) a section of comments on the subject matter and style of the painting, running to considerable length in the cases of the more important paintings; (2) a brief biography of the painter; and (3) quotations from earlier catalogues where the painting had been recorded or discussed.

Chin-kuei ts'ang-hua p'ing-shih is an exemplary catalogue in the thoroughness and quality of its research and in the clarity with which its material is organized and presented.

S.21. Ch'en Jen-t'ao 湘仁湢, Ku-kung $i-i$ shu hua muchiao-chu 故宫已佚書畫目校註・Hong Kong, 1956. [Freer].

Ch'en Jen-t'ao (1906-1968) was a modern collector. This work is an amplified and annotated list of the paintings lost from the former imperial collection.

It is based primarily on $\mathrm{Ku}-\mathrm{kung} \mathrm{i}-\mathrm{i}$ shu-chi shu hua mu-lu ssu-chung $(\underline{q} \cdot \underline{v} \cdot)$, and its secondary sources are eighteen other publications from which is derived the information on the present ownership of some of the paintings. 
This compilation is useful for verifying some of the paintings lost from the former imperial collection. However, the items enumerated here by no means account for all the lost paintings. With the publication of more and more paintings, it is possible to up-date this work and make it more complete. The absence of an index is regrettable.

S.22. Nationa1 Palace Museum 國立故宮博物院 and National Centra1 Museum 國立中央博物院, Ku-kung shu hua 1u 故宫書畫睩. 8 chuian. Taipei, 1956; revised second edition, 1965. [Freer].

Ku-kung shu hua $1 u$ is a catalogue of the calligraphy and paintings in the National Palace Museum and the National Central Museum which came under a joint administration after their move to Taiwan in 1948. The items in this catalogue represent the entire holdings in the Department of Calligraphy and Painting in the two museums except for the rubbings, k'o-ssu, embroidery, and fan paintings.

The majority of the items belong to the National Palace Museum and are from the former Ch'ing imperial collection in Peking (see Shih-ch'ü pao-chi and its two supplements, Nan-hsuin-tien tsun-ts'ang t'u-hsiang mu, Ch'a-k'u ts'ang-chu t'u-hsiang mu and Nan-hsiin-tien t'u-hsiang k'ao, qq. $\left.\underline{v}_{\cdot}\right)$. A small number of the items belong to the National Central Museum and are from the former imperial collection kept in the summer palaces in Mukden and Jehol (see Sheng-ching ku-kung shu hua lu 
and Nei-wu-pu ku-wu ch'en-1ieh-so shu hua mu-1u, qq. These are designated "Chung po 中博" to distinguish them from the National Palace Museum items.

There are three broad divisions in Kung-kung shu hua 1u. They are: (1) The Cheng-mu 正目 (the Principal List), consisting of 1,477 items of calligraphy and painting deemed worthy of being catalogued in detail. These include old (pre-Ming) works considered of undisputed authenticity, those famous old (pre-Ming) works whose attributions may be questionable but nevertheless either have an intrinsic value or have acquired a distinguished pedigree, and works of Ming and Ch'ing date considered of undisputed authenticity and high quality. (2) The Chien-mu 簡目 (the Abbreviated or Secondary List), consisting of 3,093 items of calligraphy and painting which in the opinion of the selection Committee fail to meet any of the three conditions given above. (3) Seventy-eight portraits of past emperors, consorts and sages formerly stored in the Nanhsin-tien in Peking.

The Cheng-mu occupies chiian 1-6. The first three chian are devoted to calligraphy, a total of 228 items arranged chronologically within the categories of handscrolls (88), hanging scrolls (38), and albums (102), one chiian given to each format. The paintings, totalling 1,249 items, are likewise arranged in chian 4-6: handscrolls (162), hanging scrolls (924), and albums (163). These are the three chiian which most concern us.

Each entry consists of the title; its catalogue number; ${ }^{\ddagger}$ metric measurements of the painting, its front 
and back mounting, and its end-papers; extensive quotations from the primary sources (Shih-ch'iu paochi and its two supplements, $\left.\underline{q q} \cdot \underline{v}_{\cdot}\right)$ and the secondary sources (Shih-ch'ii sui-pi and Hsi-Ch'ing cha chi, qq. $\left.\underline{v}_{.}\right)$; meticulous recording of all the seals; and a paragraph by the editors embodying any information not covered by the earlier catalogues, critical comments on conclusions reached in the earlier catalogues with which they disagree, and the results of their independent research.

Chian 7 deals with 78 portraits of former emperors and the entries follow the pattern set in the earlier chüan. Its primary source is Nan-hsin-tien $\underline{t^{\prime} u-h s i a n g ~} k^{\prime} a_{0}(\underline{q} \cdot \underline{v} \cdot)$.

Ch'ian 8 contains the Chien-mu. The 3,093 items consist of 531 pieces of calligraphy (handscrolls, 148; hanging scrol1s, 129; albums, 254), and 2,562 paintings (handscrol1s, 449; hanging scrol1s, 1,591; albums, 522). The items are listed by title, followed by the catalogue number, with no additional information.

The decision to separate the items into a cheng$\underline{m u}$ and a chien-mu is regrettable. (It seems to be a regressive step when the third part of Shih-ch'ii paochi had already abandoned the grading of items into "superior" and "secondary" categories employed in the first and second parts of that catalogue). Regardiess of the quality of the Chien-mu items, it would be preferable to have all the items fully catalogued. In the 1965 revised edition, this flaw is remedied to a certain extent, as a number of the items previously in 
the Chien-mu are moved to the Cheng-mu and given the full treatment. It is to be hoped that eventually all the items in the Chien-mu wil be fully catalogued. Apart from this one flaw, Ku-kung shu hua lu is an excellent catalogue and a model of consistency and thoroughness. It is an indispensable guide to that great collection of Chinese painting.

${ }_{\text {The }}$ catalogue number system was devised soon after the founding of the National Palace Museum in 1924, at the time of the take-over of the objects in the various palaces and halls. Each hall is designated by a character from the Ch'ien-tzu wen (Thousand-Character Classic). A catalogue number consists of a character indicating the hall in which the piece was found, followed by a number in Chinese characters indicating a particular box in the hall, and followed by a number in Arabic numberals indicating its sequence in that box. 
Index of Names

(The numbers refer to entry numbers.)

\begin{tabular}{|c|c|c|}
\hline Acker, William R.B & & $\mathrm{S} .2$ \\
\hline An $\mathrm{Ch}^{\prime} i$ & 安山支 & 57 \\
\hline An Yuian-chung & 安元忠 & 57 \\
\hline Ayurparibhadra & 爱䏍称拔力八達 & 17 \\
\hline Chan Ching-feng & 詹景凰 & 28 \\
\hline Chang Chao & 張照 & $58 a, 59 a$ \\
\hline Chang Ch'eng-chih & 張誠之 & 34 \\
\hline Chang Ch'ou & 偯表 & $33,34,35,36,37$ \\
\hline Chang I-sheng & 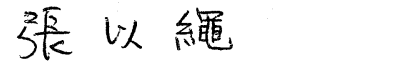 & 34 \\
\hline Chang Keng & 张座 & 64 \\
\hline Chang Mou-shih & 張茂富 & 34 \\
\hline Chang Ta-yung & 張大锯 & 76 \\
\hline Chang T'ai-chieh & 張泰栺 & 41 \\
\hline Chang Tan-chia & 张敦嘉 & 34 \\
\hline Chang T'ing-chi & 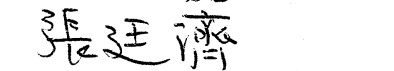 & 82 \\
\hline Chang Tzu-ho & 張子和 & 34 \\
\hline Chang Wei-ch'ing & 張倠虔 & 34 \\
\hline Chang Yen-yüan & 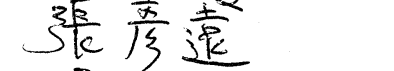 & $\mathrm{S} .2$ \\
\hline Chang Yuian-su & $\frac{3 \sqrt{3}}{k}$ え素 & 34 \\
\hline Chang Yüeh-chih & 卧 䞎衣 & 34 \\
\hline Chao Ch'i-mei & 趙肖域美 & 30,31 \\
\hline Chao Ling-chih & 走肖令轫 & S. 5 \\
\hline
\end{tabular}




\begin{tabular}{|c|c|c|}
\hline Ch'en Chi-ju & 陳 維儒 & 39,43 \\
\hline Ch'en Chuan & 陳撰 & 62 \\
\hline Ch'en Ch'uo & & 65 \\
\hline Ch'en Fu-liang & 良 & 13 \\
\hline Ch'en Jen-t'ao & 许重 & $S .20, S .21$ \\
\hline $\mathrm{Ch}^{\prime}$ en $\mathrm{K}^{\prime}$ uei & 陆 & 11 \\
\hline Ch'en K'uei-1in & 潾 & 101 \\
\hline Ch'en Tsung-i & & 79 \\
\hline Chia-ch'ing emperor & & $58 c, 59 c$ \\
\hline Chia Ssu-tao & 冝似迫 & S. 7 \\
\hline Chiang Kuang-hsui & 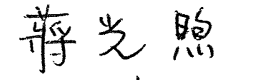 & 83 \\
\hline Chiao Hung & 住立立 & 30 \\
\hline Ch'ien-1ung emperor & 龺己 & $\begin{array}{l}58 \mathrm{a}, 58 \mathrm{~b}, 59 \mathrm{a}, \\
60,61\end{array}$ \\
\hline $\mathrm{Ch}^{\prime}$ in $\mathrm{Ch}^{\prime}$ ien & 秦 $r^{z}$ & 108 \\
\hline Chin-liang & & 100 \\
\hline $\mathrm{Ch}^{\prime}$ in Ping-wen & 奏 4 & 108 \\
\hline $\mathrm{Ch}^{\prime}$ in Ssu-1in & 点 业 & 30 \\
\hline Ch'ing-fou-shan-jen & 青浮山人 & 71 \\
\hline Chou Erh-hsïeh & 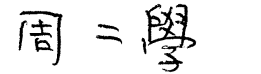 & 56 \\
\hline Chou Mi & 周 密 & 15 \\
\hline Chou Shih-Iin & 周石材 & 23 \\
\hline Chou Yuin-ch'ing & 周霡 $\frac{\text { 青 }}{}$ & Preface \\
\hline Chu Chih-ch'ih & 牛之音 & 45 \\
\hline Chu Ching-hsian & 来苦京 & $\mathrm{S} .1$ \\
\hline
\end{tabular}


Chu Hsi

Chu I-tsun

Chu Ts'un-1i

Chüieh-fan Te-hung

Ch'ung I

Fang Chiin-i

Fei Nien-tz'u

Ferguson, John C.

Haisan

Han Ang

Han Shih-neng

Han T'ai-hua

Ho Liang-chün

Ho Yii

Hsia Wen-yen

Hsiang-ko-1a-chi

Hsiang Yüan-pien

Hsii Ch'ien-hsieh
Gulik, R.H. van
朱喜

未䎹尊

来存理

婜算德洪

崇 粨

方䛜葟

费念趝
12

53

18,30

8

103

87

75

Preface

56

17

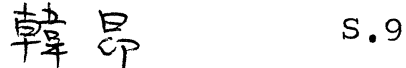

南贲世能 32, 33

龺龺春恶 84

何家俊 24

行夾昱 105

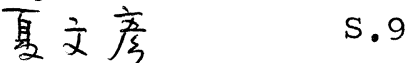

祥 $\frac{\text { DI }}{y}+\frac{1}{\frac{1}{1}} \pm 17$

项方泣 44

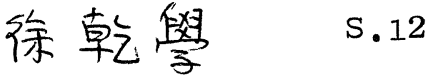

Hsian-t'ung emperor, see $P^{\prime} u-i$

Hu Chi-t'ang

胡䅜党

78

$\mathrm{Hu}$ Ch'iao

胡嶠

S. 4

Hu Ching

胡苟文

$58 \mathrm{c}, 59 \mathrm{c}, 72,73$

Hua Hsia
苹夏 


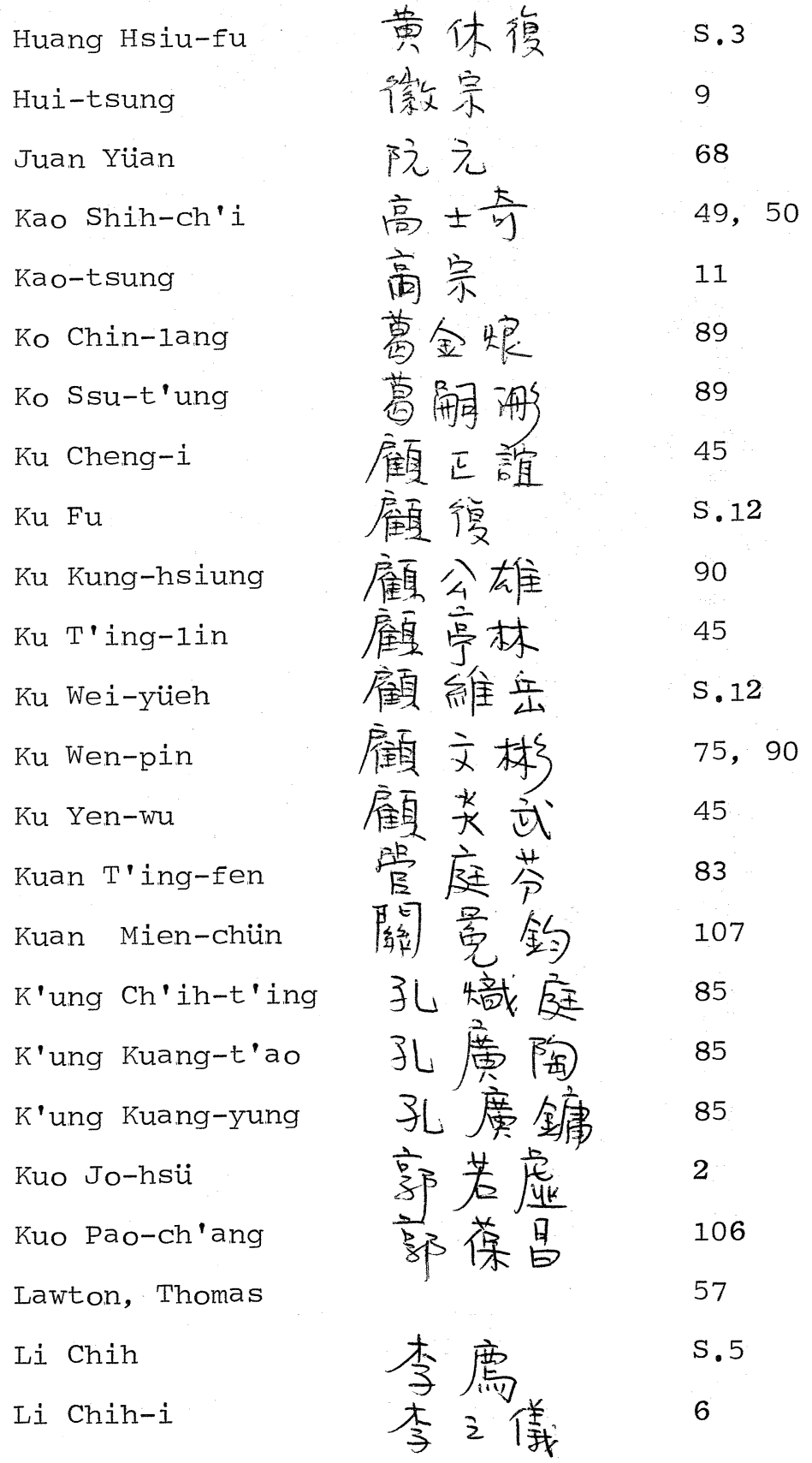


Ii Fang

李放

Ii Jih-hua

Li $O$

Li Pao-hsin

Li Tiao-yuian

Li T'ien

Li Tso-hsien

Li Tsu-nien

Li Yü-fen

Liang Chang-chï

Lien Ch'üan

Iiu Tao-ch'un

Lo Chen-yii

Iu Hsin-yiian

Iu Shih-hua

Maeda, Robert $\mathrm{J}$.

Mao Chin

Mao Wei

Mi Fei

National Central Museum

无 $\frac{\overline{4}}{\text { 日 }}$

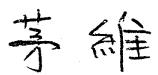

米 $\frac{H}{p}$
102

38

55

96,102

67

S. 3

86

54

94,97

81

S. 16

$3, S .4$

50, S. 14

92,93

66

10

$5,8,12,14$

32

4, 9

S. 22

S.18, S.22

S. 15

75

75 


\begin{tabular}{|c|c|c|}
\hline P'ang Yüan-chi & 龐元漓 & 98 \\
\hline P'ei Ching-fu & 裴 & S.17 \\
\hline P'ei Hsiao-yian & & 1 \\
\hline Pien Yung-yü & 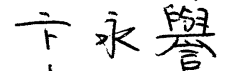 & 47 \\
\hline$P^{\prime} u$-chieh & 浦傑 & $\mathrm{S} .18$ \\
\hline$-i$ & 溥侍 & S.18 \\
\hline
\end{tabular}

Sengge Ragi, see Hsiang-ko-1a-chi

\begin{tabular}{|c|c|c|}
\hline Shao Sung-nien & 松年 & 95 \\
\hline Shen T'ao & 农㴗 & 84 \\
\hline Shen Te-ch'ien & 讴德潜 & 63 \\
\hline $\begin{array}{l}\text { Shih-pai-chai chu-jen } \\
\text { Soper, Alexander Cobur }\end{array}$ & 十百商余人 & $\begin{array}{l}69 \\
2, \mathrm{~S} .1, \mathrm{~S} .5\end{array}$ \\
\hline Su Shih & 蕉車式 & $6,15, S .5$ \\
\hline Su Sung & 蕉公自 & 5 \\
\hline $\mathrm{Su}$ Tsung-jen & 蘇宗仁 & S.19 \\
\hline Sun Ch'eng-tse & 捇水溸 & 46 \\
\hline Sun Hsing-yen & 榇星经 & 79 \\
\hline Sun Kung & 棌錙 & 29 \\
\hline Sung Lo & 穼苼 & 54,97 \\
\hline Tämur & 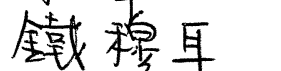 & 17 \\
\hline T'ang Hou & 湿点 & 5.8 \\
\hline T'ang Yün-mo & 晹允謨 & 16 \\
\hline T'ao Liang & 隐枳 & 77 \\
\hline Teng Ch'un & 登椿 & 10 \\
\hline
\end{tabular}




\begin{tabular}{|c|c|c|}
\hline Ting Fu-pao & 丁褔保 & Preface \\
\hline Ts'ai Yï-mou & 蔡 每立 & 99 \\
\hline Tse Lang & 迮 & S. 13 \\
\hline Tu Chao-pin & & 63 \\
\hline Tu Jui-Iien & 杜 & 88 \\
\hline $\mathrm{Tu} \mathrm{Mu}$ & & 19,63 \\
\hline Tuan-fang & 立耑 & 96, S. 19 \\
\hline Tung Ch'i-Ch'ang & 董其昌 & $39,40,71$ \\
\hline Tung T'ing & 董店 & 39 \\
\hline Tung Yu & 董迫 & 7 \\
\hline Vandier-Nicolas, Nicole & & 4 \\
\hline Wan-yen Ching-hsien & 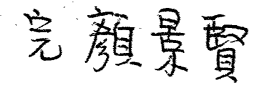 & S.19 \\
\hline Wang Ai-ching & 汪空菜判 & 44 \\
\hline Wang Chieh & & $58 \mathrm{~b}, \quad 59 \mathrm{~b}$ \\
\hline Wang Chih-teng & 王喥 & S. 10 \\
\hline Wang $K^{\prime} \mathrm{o}-\mathrm{yii}$ & 诖研王。 & 44 \\
\hline Wang Shan & $\mp$ & 54 \\
\hline Wang Shih-chen & $\pm t$ & $25,26,29$ \\
\hline Wang Shih-min & 王時每父 & 97 \\
\hline Wang Shih-mou & 王世格来 & 27 \\
\hline Wang Shih-yian & 汪士う & 104 \\
\hline Wang To & 王鉎睪 & 45 \\
\hline Wang Tse & 王濐 & 78 \\
\hline Wang Wen-chih & \pm 文治 & 70,71 \\
\hline
\end{tabular}




\begin{tabular}{|c|c|c|}
\hline Wang Yüan-ch'i & 王原衩 & 51 \\
\hline Wang Yün & & $\mathrm{S} .6$ \\
\hline Wen Chia & & 21 \\
\hline Wu Ch'i-chen & 吴其自 & S.11 \\
\hline Wu Chih-ying & 吴芝 & S.16 \\
\hline Wu Hsi-ch'i & 点钽䘟 & 50 \\
\hline Wu Hsiu & 奌 修 & 74 \\
\hline Wu Jung-kuang & 吴䒜光 & 80 \\
\hline Wu Pi-chiang & 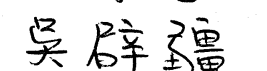 & 11 \\
\hline Wu Sheng & 点升 & 54 \\
\hline Yang Ch'ing-lin & & 95 \\
\hline Yang En-shou & & 91 \\
\hline Yang Wang-hsiu & 㛫王休 & 11 \\
\hline Yang Wu-pu & 㮛無補 & 40 \\
\hline Yao Chi-heng & 姚 & 52 \\
\hline Yeh Shih & 菜滴 & 14 \\
\hline Yen Sung & 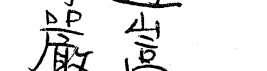 & $21,22,23$ \\
\hline Yü Feng-ch'ing & & 42 \\
\hline Yï Shao-sung & & Preface \\
\hline Yuian Chüeh & 专桶小 & 17 \\
\hline Yün Shou-p'ing & 䭪堛年 & 48 \\
\hline
\end{tabular}




\section{Index of Titles}

(The numbers refer to entry numbers.)

Ai-jih-yin-1ou shu hua 1u 爱日吟棲書畵錄

Ch'a-k'u ts'ang-chu t'u-hsiang mu

菒庫藏斯圆像目

Chen-chi jih 1u 真靕日镍

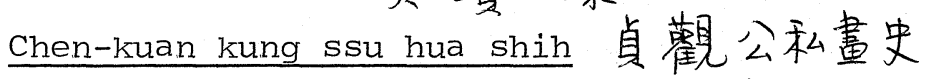

Ch'eng-tu ming-hua 1u 成都名愠錄, see

I-chou ming-hua lu

Chiang-ts'un hsiao-hsia Iu 江炉生肖夏銥

Chiang-ts'un shu hua mu 江村書畵目

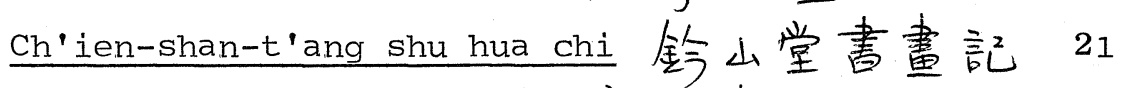

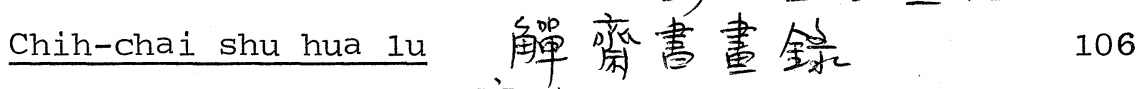

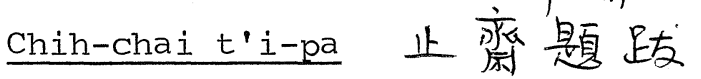

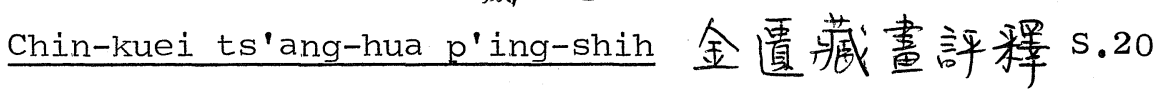

Chinese Pictorial Art as Viewed by the Connoisseur 56

Ch'ing-ho shu hua fang 清河青書舟方 36

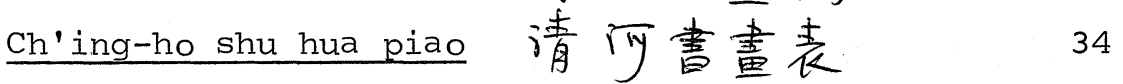

Ch'ing-hsia-kuan Iun-hua chüeh-chü

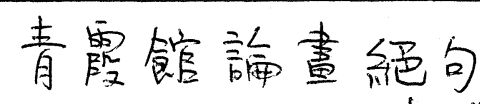

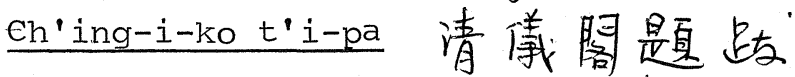

Ch'ing-jung-chu-shih chi 请容居士集

The Chronicle of Suchou Painters, see

Wu-chün tan-ch'ing chih 
Chu-chia ts'ang-hua pu 諸家藏䡒謴 67

Chu-t'ang wen-kao 竹堂文䅧 99

Chu Wo-an ts'ang shu hua mu 朱卧荤藏書重目 45

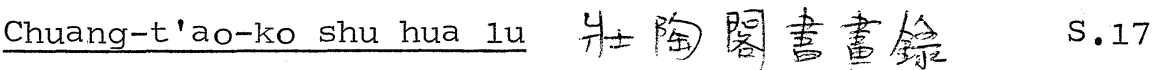

Fa-shu ming-hua chien wen piao 法妻名賗县既表

see Shu hua chien wen piao

Hai-wang-ts'un so-chien shu hua iu ts'an-kao

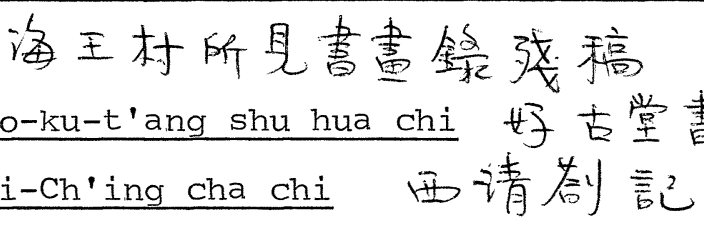

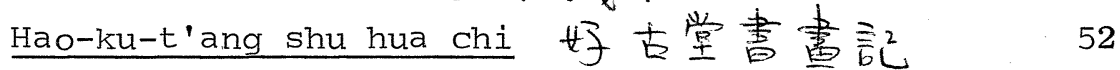

Hsi-Ch'ing cha chi 亚请萮言己 72

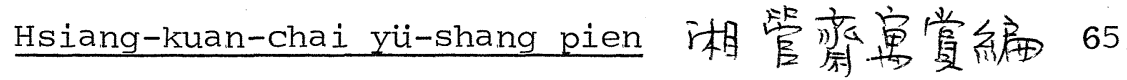

Hsiao-wan-1iu-t'ang ts'ang hua mu

小蕾柳堂藏畵目

Hsin-ch'ou hsiao-hsia chi 辛五销夏言已

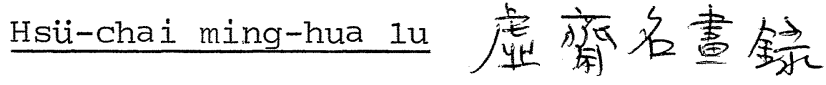

Hsü-ching-chai yün-yen kuo-yen $1 u$

洎静栾雲姆因漫眼銥

Hsian-ho hua p'u 宣和畫譜

Hsuian-hsüeh-chai shu hua yü-mu pi-chi

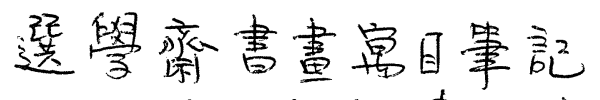

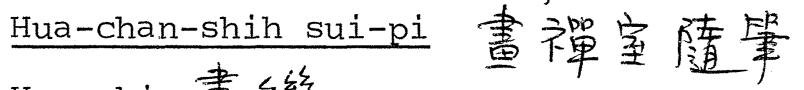

Hua chi 書䋡

Hua chien 畫鑑

S. 8

Hua chii 書據 
Hua fa 畫法

Hua p'in 畫 $R_{12}^{R}$, see Te-yi-chai hua-p'in

Hua shih 車串

"Hua shih Chen-shang-chai fu chu

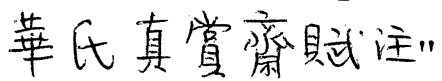

Hua-yian pi-chi 書苑秘咒

Hui-ant'i-pa 狍庵道浦

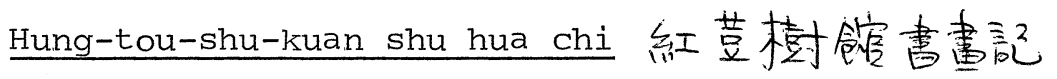

I-chou ming-hua 1u 道州名畫銥

S. 3

I-chüeh pien 一角編

I-ku-t'ang t'i-pa 佯雇自堂是直路

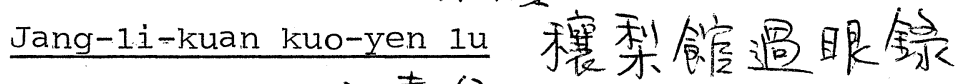

Jung-t'ai chi 容堂集

Jung-t'ai pieh-chi 窟壱呈住

Kao Wen-k'o Kung shu hua chen ying mu

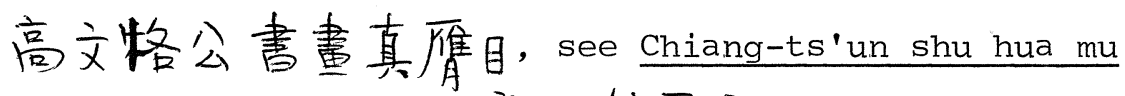
Keng-tzu hsiao-hsia chi 庚子銷夏記

Ku-ch'i t'i-pa 姑滛是路

6

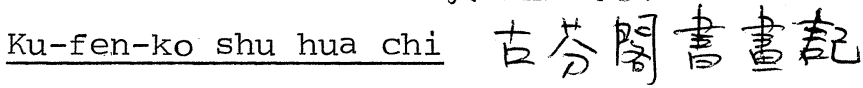

Ku-kung $i-i$ shu hua mu chiao-chu

故宫已佚書畵目校言主

Ku-kung $i-i$ shu-chi shu hua mu-lu ssu-chung

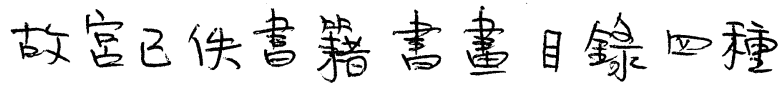

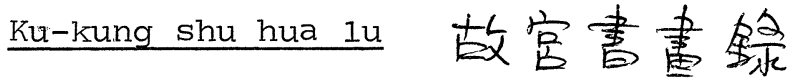


Ku-yian ts'ui-1u 古縞萃昉永

K'uai-yui-t'ang t'i-pa 快雨堂题路”70

Kuang-ch'uan hua pa 廣川囊政 7

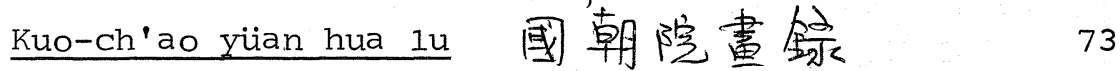

Kuo-yün-1ou shu hua chi 嗃雪梙書意記 90

Li-tai chu-Iu hua mu 歴代著铰貫目 Preface

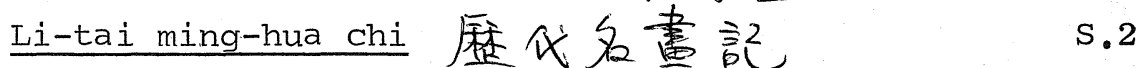

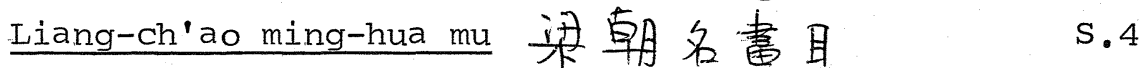

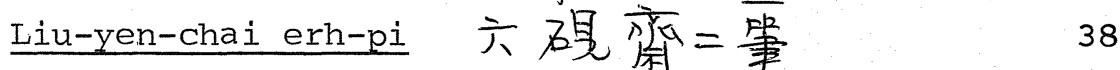

Liu-yen-chai pi-chi 六䃆率筆記 38

Liu-yen-chai san-pi 六码率产三筆 38

"Lu-kuo Ta-chang-kung-chu t'u-hua chi

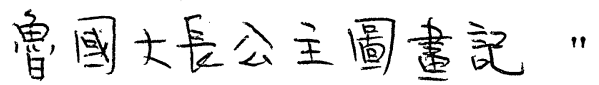

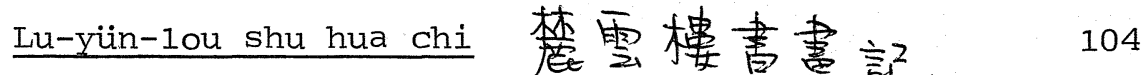

Mai-wang-kuan shu mu 脉望飡昰目的31

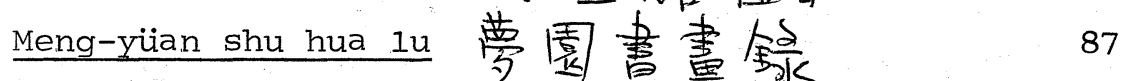

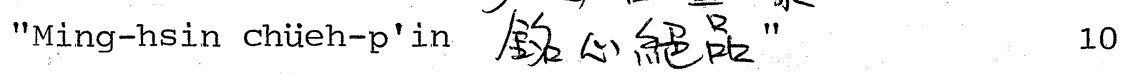

Mo-yiian hui-kuan 墨線案整 57

Nan-hsiun-tien $t^{\prime} u-h s i a n g k^{\prime} a 0$ 南薰殿圆像考 59c

Nan-hsin-tien tsun-ts'ang t'u-hsiang mu

南黄展尊茙圆像目

Nan-Sung kuan-ko $1 \mathrm{u}$

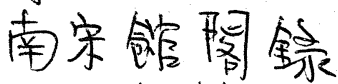

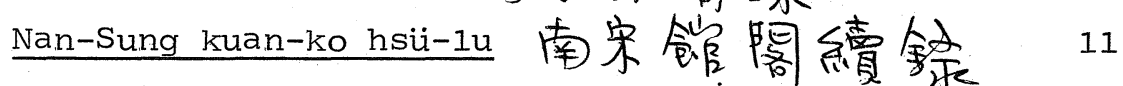

Nan-Sung yiian hua 1u 南宋院畫鈜 
Nan-t'ien hua pa 南由畫跂

Nan-yang ming-hua piao 南陽名畫表

Nei-wu-pu ku-wu ch'en-lieh-so shu hua mu-1u

内纾部古物陳列所畫畫目睩

Ni ku Iu 妮古㖉水

ou-po-1o-shih shu hua kuo-mu k'ao

區互鉢羅窒意畫道目考

Pao hui 1u 䆩繒铭

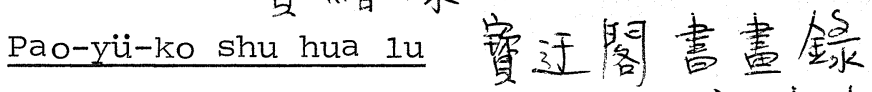

P'ei-wen-chai shu hua p'u 佩文蔡書畫譜

Pen-ch'ao ming-hua p'ing 木朝名畫評

see Sheng-ch'ao ming-hua p'ing

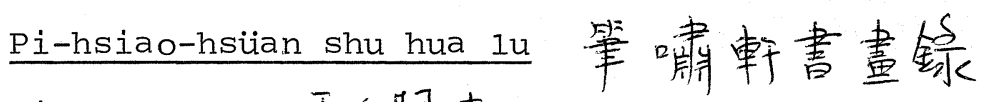

Pi-ko hua mu 秘阴蕃目

Pi-tien chu-1in 秘殿珠林

Pi-tien chu-1in hsiu-pien 秘展珠林縜編

Pi-tien chu-1in san-pien 秘殿珠林三編

$58 b$

Pieh-hsia-chai shu hua 1u 别下率書畫䤼

$58 \mathrm{C}$

P'ing-chin-kuan chien-ts'ang shu hua chi

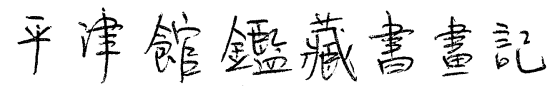

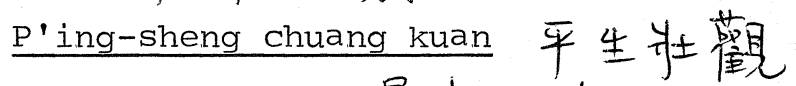

P'u hua chi yiu 曝畫紀食余

P'u-shu-t'ing shu hua pa 曝書亭書畫政

San-ch'iu-ko shu hua $1 \mathrm{u}$ 三秋陶書書銥 
San-wan liu-ch'ien ch'ing hu-chung hua ch'uan iu

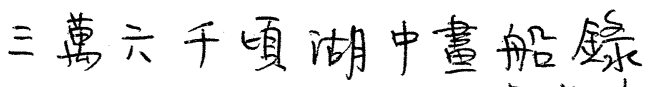

San-yï-t'ang shu hua mu 三虞堂啛畫目

Shan-hu mu-nan 删哺木英隹

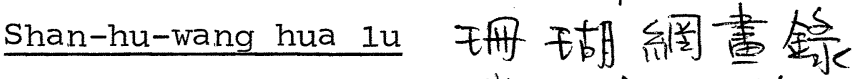

Shang-yen su-hsin Iu

$$
\text { 賞延素心塗 }
$$

Sheng-ch'ao ming-hua p'ing 聖朝名畵 䛲

Sheng-ching ku-kung shu hua 1u 盛京故害青畵制 100 Shih-ch'ii pao-chi 不些筫及

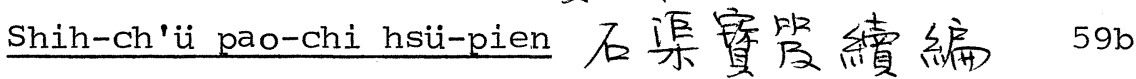

Shih-ch'ii pao-chi san-pien 石渠察䈆三妒房 59c

Shih-ch'iu pao-chi san-pien mu-lu

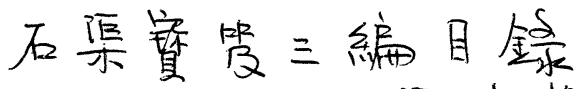

Shih-ch'ui sui-pi $大$ 哚陵紫

Shih-ku-t'ang shu hua hui-k'ao

$$
\text { 武古堂青書察莎 }
$$

Shih-men t'i-pa 不胢旦自此

Shih-pai-chai shu hua lu

Shu hua chi 啛書 記

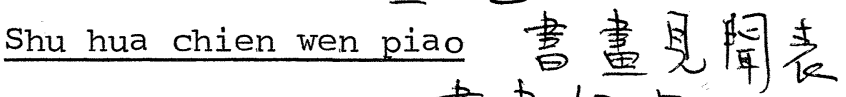

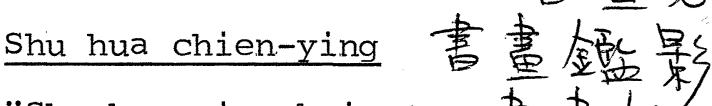

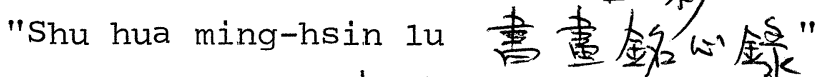

Shu hua mu-1u 啛書目鈳e

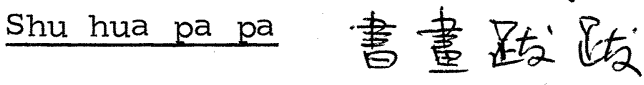


Shu hua shu-lu chieh-t'i 書書鉱解是 Preface Shu hua shu-1u chieh-t'i pu chia-pien

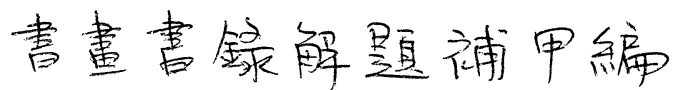

Shui-hsin t'i-pa sk心是㙄

Ssu ch'ao pao hui lu w朝整䌁銶

see Pao hui lu

Ssu-k'u ch'uian-shu 为庚全書

Ssu-k'u ch'üan-shu chien-ming mu-lu

四庫全書简明目全永

Ssu-k'u ch'uian-shu tsung-mu t'i-yao

四㡽全書總目提要

$1, \mathrm{~S} .11$

ssu-pu tsung-1u i-shu pien

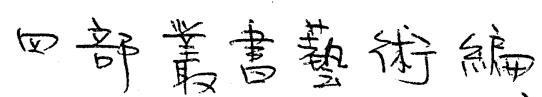

$1, \mathrm{~S} .11$

Sung-ch'ao ming-hua p'ing 案朝名素評

see Sheng-ch'ao ming-hua p'ing

Sung Chung-hsing-kuan-ko ch'u-ts'ang shu mu

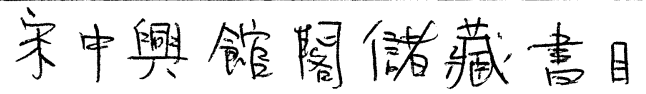

Sung Chung-hsing-kuan-ko ch'u-ts'ang t'u-hua chi

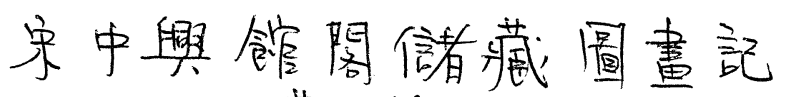

Preface

Ta-kuan Iu 大㺃目銥水

T'ang-ch'ao ming-hua lu 唐朝名量銥

Te-yü-chai hua-p'in 德䧉葆書品

S. 1

T'ieh-wang shan-hu 琙裲珊瑚(16 chian)

S. 5

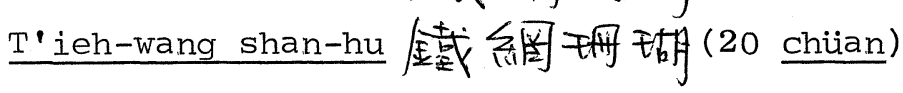




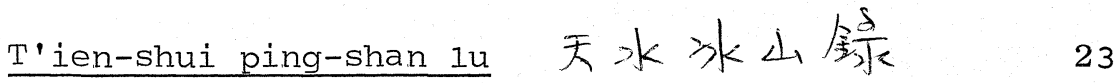

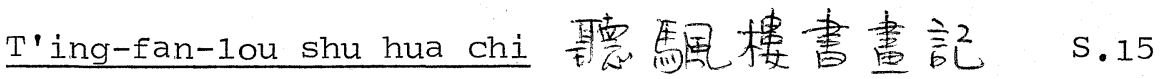

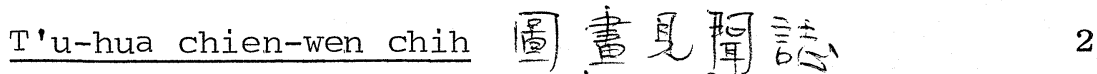

T'u hua ching-i shih 圆畫精意諳 64

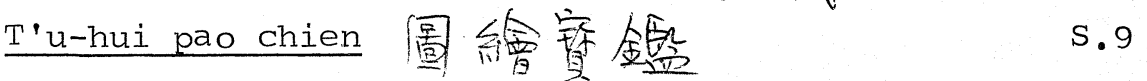

T'ui-an so-ts'ang chin-shih shu hua pa

退盒所藏金石畫跍

Tung Hua-t'ing shu hua 1u 董苹应書畫銢 71

Tung-t'u hsian-1an pien 東嘈玄覽編 28

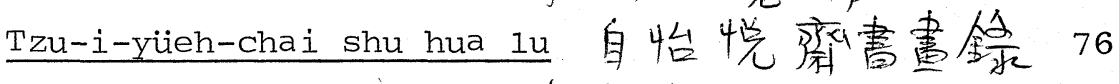

Wang Feng-ch'ang chi 王奉裳集

27

Wang Feng-ch'ang shu hua t'i-pa

王奉常書莗夏跂

"Wang Shih-chen Erh-ya-lou so-ts'ang ming-hua

王世首爾雅棲所藏名書"

"Wang Shih-mou Tan-pu hua p'in

王世淴澹闻畫品"

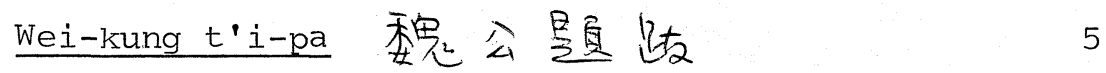

Wu-chün tan-ch'ing chin 吴郡丹青志江

Wu-i-yu-i-chai lun-hua shih

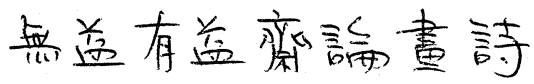

96

Wu-1in chang-ku 武林掌故

Wu-tai ming-hua pu-i 五代名喜禣遺 $\mathrm{S} .4$

Wu-Yüieh so-chien shu hua 1u 吴越所具書書舒 66 
Yen-chou-shan-jen kao 拿州山人稿 25,26, 29 Yen-chou-shan-jen hsui-kao 弇州山人繵稿的 25

Yen-fu pien 眼褔編 91

"Yen shih shu hua chi 䖍氏書畫記" 22

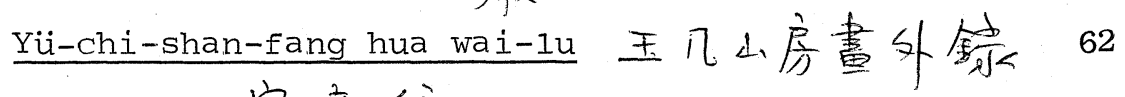
Yii-ipien 宙意編 19

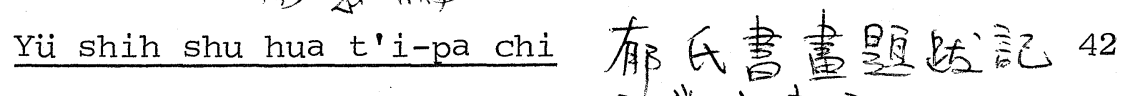
Yü-yui-t'ang shu hua chi 王雨堂書畫記 84

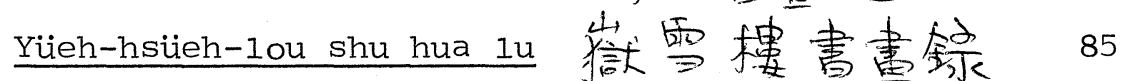
Yuieh-sheng pieh-1u 悦生别蜍永 $\quad 5.7$

Yiieh-sheng so-ts'ang shu hua pieh-1u

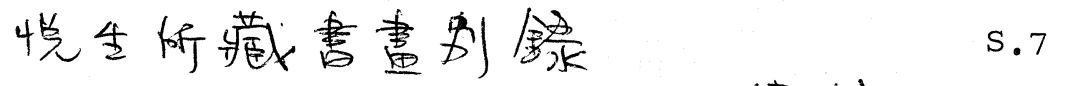

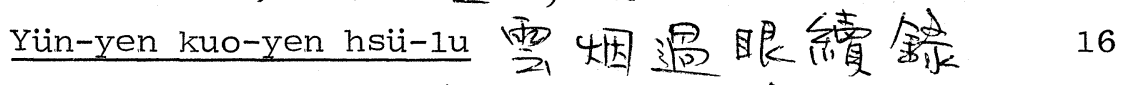

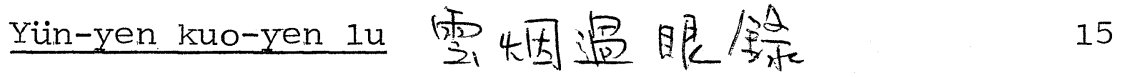




\section{MICHIGAN PAPERS IN CHINESE STUDIES}

No. 1, The Chinese Economy, 1912-1949, by Albert Feuerwerker.

No. 2, The Cultural Revolution: 1967 in Review, four essays by Michel Oksenberg, Carl Riskin, Robert Scalapino, and Ezra Vogel.

No. 3, Two Studies in Chinese Literature: "One Aspect of Form in the Arias of Yüan Opera" by Dale Johnson; and "Hsü K'O's Huang Shan Travel Diaries" translated by Li Chi, with an introduction, commentary, notes, and bibliography by Chun-shu Chang.

No. 4, Early Communist China: Two Studies: "The Fut'ien Incident" by Ronald Suleski; and "Agrarian Reform in Kwangtung, 1950-1953" by Daniel Bays.

No. 5, The Chinese Economy, ca. 1870-1911, by Albert Feuerwerker.

No. 6, Chinese Paintings in Chinese Publication, 19561968: An Annotated Bibliography and An Index to the Paintings, by E. J. Laing.

No. 7, The Treaty Ports and China's Modernization: What Went Wrong? by Rhoads Murphey .

No. 8, Two Twelfth Century Texts on Chinese Painting, "Shan-shui ch'un-ch'üan chi" by Han Cho, and chapters nine and ten of "Hua-chi" by Teng Ch'un, translated by Robert J. Maeda.

No. 9, The Economy of Communist China, 1949-1969, by Chu-yuan Cheng.

No. 10, Educated Youth and the Cultural Revolution in China, by Martin Singer.

No. Il, Premodern China: A Bibliographical Introduction, by Chun-shu Chang.

No. 12, Two Studies on Ming History, by Charles 0. Hucker. (continued) 
No. 13, Nineteenth Century China: Five Imperialist Perspectives, selected by Dilip Basu, edited with an introduction by Rhoads Murphey.

No. 14, Modern China, 1840-1972: An Introduction to Sources and Research Aids, by Andrew J. Nathan.

No. 15, Women in China: Studies in Social Change and Feminism, edited with an introduction by Marilyn B. Young.

No. 16, An Annotated Bibliography of Chinese Painting Catalogues and Related Texts, by Hin-cheung Lovell.

$$
\begin{gathered}
\text { Price: } \$ 3.00 \text { (US) each, } \\
\text { except } \$ 3.50 \text { for special issues } \# 6 \text { and \#15 }
\end{gathered}
$$

\author{
* $\quad * \quad *$ \\ MICHIGAN ABSTRACTS OF CHINESE AND \\ JAPANESE WORKS ON CHINESE HISTORY
}

No. 1, The Ming Tribute Grain System by Hoshi Ayao, translated by Mark Elvin.

No. 2, Commerce and Society in Sung China by Shiba Yoshinobu, translated by Mark Elvin.

No. 3, Transport in Transition: The Evolution of Traditional Shipping in China, translations by Andrew Watson.

$$
\begin{array}{rrr}
\text { Price: } & \$ 3.50 \text { (US) each } \\
* & * & *
\end{array}
$$

Michigan Papers and Abstracts available from:

$$
\begin{gathered}
\text { Center for Chinese Studies } \\
\text { University of Michigan } \\
\text { Lane Hall } \\
\text { Ann Arbor, Michigan } 48104 \text { USA }
\end{gathered}
$$


